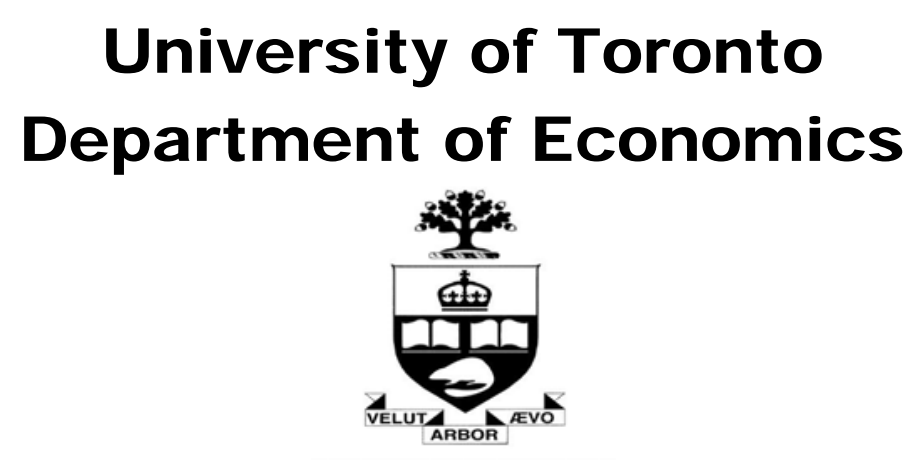

Working Paper 463

Money Matters: A Critique of the Postan Thesis on Medieval Population, Prices, and Wages

By John H. MUNRO

August 08, 2012 


\section{Department of Economics \\ University of Toronto \\ 150 St. George Street \\ Toronto, Ontario M5S 3G7 \\ Canada}

\section{'Money Matters': A Critique of the Postan Thesis on Medieval Population, Prices, and Wages}

Working Paper no. 463 (MUNRO: no. 44)

Repec Handle: tecipa-463

by John Munro

Wednesday, 8 August 2012

Copyright (C) by John Munro 2012

Department of Economics

University of Toronto

Author's e-mail: munro5@chass.utoronto.ca

http://www.economics.utoronto.ca/munro5

On-line version: http://www.economics.utoronto.ca/index.php/index/research/workingPaperDetails/463

Keywords: Ricardo; Malthus; Postan; marginal productivity; population; nominal wages; real wages; agricultural labourers; building craftsmen; masters and journeymen; money; bullion; credit; inflation; deflation; relative prices; England; Flanders; Middle Ages

JEL Classifications: E 31; E41; E42; E51; E52; E62; F33; H11; H27; N13; N23; N43 


\title{
'Money Matters': A Critique of the Postan Thesis on Medieval Population, Prices, and Wages
}

\begin{abstract}
:
This paper is a critique of Michael Postan's famous Malthusian-Ricardo model demonstrating that late-medieval prices and wages were essentially determined by demographic factors, especially after the Black Death, while contending that monetary factors played no role in determining prices or wages. His central argument is simple: that rapid and drastic depopulation (falling perhaps from ca. 1320) - by about 50\% in England ca. 1450 - drastically altered the land:labour ratio so that real wages increased, both from a rise in the marginal productivity of labour and also from a corresponding fall in the costs of foodstuffs. As Ricardo had argued, a population decline necessarily led to lower grain prices, reduced rents, as well as to increased real wages. A related part of Postan's model is the contention that grain prices alone fell after the Black Death, while prices of most livestock products and especially industrial products rose, thus producing a widening divergence in commodity prices in late-medieval Europe.
\end{abstract}

This paper seeks to show that monetary factors also played a role in determining or influencing both prices and real wages in medieval Europe, both before and after the Black Death. The evidence produced here reveals cycles of inflation and deflation from the late $12^{\text {th }}$ to early $16^{\text {th }}$ century: with a sharp deflation before the Black Death, an equally severe inflation for the quarter century following the Black Death, which was then followed by steep deflation into the early $15^{\text {th }}$ century, after which the deflationary trend was broken only by the final phase of the Hundred Years' War and by civil wars in Flanders. Deflation resumed in the very late $15^{\text {th }}$ century, enduring until the eve of the inflationary European Price Revolution, from ca. 1515-20 to ca. 1650. The tables in this paper demonstrate that during both periods of inflation and of deflation, agricultural and industrial prices rose and fell together, if not necessarily in full tandem. These cycles of inflation and deflation were essentially due to monetary and not demographic factors; but differences in relative prices can be explained as well by real factors. Thus the core theme of the paper: 'money matters', though monetary factors certainly do not explain all economic phenomena.

The final section of the paper deals with post-Plague real wages, demonstrating first a sharp fall in real wages following the Black Death and then a sharp rise in real wages from the later $14^{\text {th }}$ century. That was essentially a result and function of downward nominal wage-stickiness during the deflations that took place in this era, especially during the two 'bullion' famines of ca. 1370 - ca. 1415 and ca. 1440 - 1475. An examination of the root causes of wage-stickiness, essentially a post-Plague phenomenon, has been more thoroughly explored in many other of my online working papers and numerous publications (since 2003).

The statistical evidence on prices and wages is taken from both England and Flanders (up to ca. 1500): i.e., from both a basically rural agrarian economy (England) and a much more commercialized, industrialized, urbanized economy (Flanders). If such radically different economies experienced the same trends in commodity prices and wages (nominal and real) - as they did, the agrarian-based Ricardo model cannot provide the full explanation - so that again a role for monetary factors must be allowed, all the more so in light of the detailed monetary evidence supplied in this paper.

Keywords: Ricardo; Malthus; Postan; marginal productivity; population; nominal wages; real wages; agricultural labourers; building craftsmen; masters and journeymen; money; bullion; credit; inflation; deflation; relative prices; England; Flanders; Middle Ages

JEL Classifications: E 31; E41; E42; E51; E52; E62; F33; H11; H27; N13; N23; N43 
'Money Matters': A Critique of the Postan Thesis on Medieval Population, Prices, and Wages

John Munro (University of Toronto)

\section{Postan and the medieval population question}

For the English-speaking world, no historian has had a more profound influence, in the past half century, upon our conception of the later-medieval economy and society than has the late Michael Moïssey Postan (1899-1981) of Cambridge University. While his first major contributions were in medieval trade and finance, ${ }^{1}$ which have all basically stood the tests of time, his greatest fame lies in his analyses of the relationships between demographic, economic, and social changes in medieval England, though more generally also in medieval Europe. For their respective areas of medieval Europe, a very similar claim may be made for the equally eminent Georges Duby (for France), Wilhelm Abel (for Germany and Central Europe), and B.H. Slicher Van Bath (for the Low Countries). ${ }^{2}$ Though none of these historians ever claimed that population was in itself the ultimate 'prime mover', nevertheless they certainly portrayed demographic factors to be the primary motor explaining economic and social changes in medieval Europe.

This study focuses solely, however, on the views of Michael Postan: in particular, his MalthusianRicardian model on the role of demographic forces in the late-medieval economy, one that permits no role for monetary factors. This study will test Postan's model using evidence from two totally different latemedieval economies: England, essentially agrarian; and Flanders, far more industrialized and urban. If the Postan agrarian-oriented model is correct, we should thus perceive differences between England and Flanders

${ }^{1}$ Michael Postan, 'Credit in Medieval Trade’, Economic History Review, 1st ser. 1 (1928), 234-61, reprinted in Michael Postan, Medieval Trade and Finance (Cambridge: Cambridge University Press, 1973), pp. 1 - 27; 'Private Financial Instruments in Medieval England', Vierteljahrschrift für Sozial- und Wirtschaftsgeschichte, 22 (1930), repr. in Postan, Medieval Trade, pp. 28-64; 'The Economic and Political Relations of England with the Hanse from 1400 to 1475', in Studies in English Trade in the Fifteenth Century, ed. Eileen Power and Michael Postan (London, 1933; reprinted London: Routledge, 1966), pp. 91154; 'The Trade of Medieval Europe: the North,' in The Cambridge Economic History of Europe , Vol. II: Trade and Industry in the Middle Ages, ed. Michael Postan and E.E. Rich (Cambridge: Cambridge University Press, 1952), pp. 119-256; repr. with a few changes in the 2d ed.., Michael Postan and Edward Miller eds. (Cambridge, 1987), 2:168-305, and in Postan, Medieval Trade, pp. 92-31 (with bibliography); 'Partnership in English Medieval Commerce’, Rivista della società 11 (1957), repr. in Postan, Medieval Trade, pp. 65-91.

2 Georges Duby, L'économie rurale et la vie des campagnes dans l'Occident médiéval (Paris: Aubier, 1962), trans. by Cynthia Postan as Rural Economy and Country Life in the Medieval West (London: E. Arnold, 1968); Wilhelm Abel, Agrarkrisen und Agrarkonjunktur: Geschichte des Land- und Ernährungswirtschaft Mitteleuropas seit den hohen Mittlealter, 3rd edn. (Berlin: Parey, 1978), trans. by Olive Ordish as Agricultural Fluctuations in Europe from the Thirteenth to the Twentieth Centuries (London: Methuen, 1980); with a forward by Joan Thirsk; Wilhelm Abel, Die Wüstungen des ausgehenden Mittelalters, Quellen und Forschungen zur Agrargeschichte, vol. 1 (Stuttgart: G. Fischer, 1976); B.H. Slicher-Van Bath, B.H., De agrarische geschiedenis van West Europa, 500 - 1850, trans. by Olive Ordish as The Agrarian History of Western Europe, A.D. 500-1850 (London: E. Arnold, 1963). 
in the behaviour of their late-medieval prices and wages.

Postan’s most profound influence on English economic history began with two papers on population change, published in 1950 and 1951; and his last was a textbook survey, largely devoted to demography and agriculture, published in 1972. ${ }^{3}$ Consequently, any discussion of Postan's model must begin with medieval demography (up to ca. 1520). Most historians now believe that western Europe's population at least doubled from the tenth to early fourteenth century and, further, that the most rapid growth took place during the socalled 'long thirteenth century', from ca. 1180 to ca. 1315. But there still remains considerable dispute about when England itself reached its maximum population, and at what level. While many historians continue to believe that English population continued to grow until the Black Death, few would now accept the pioneering estimate of J. C. Russell: at 3.7 million. ${ }^{4}$ Postan, while warning his readers to eschew the 'lure of aggregates', rejected Russell's views by contending, first, that it had peaked much earlier, about the time of the Great Famine (1315-22), and second, at a far higher level, possibly six to eight million - or even more precisely 'nearer 7 millions' ${ }^{5}$ H. E. Hallam subsequently contended, with rather daring precision, that the

${ }^{3}$ Michael Postan, 'Some Economic Evidence of Declining Population in the Later Middle Ages,' Economic History Review, 2nd ser.. 2:1 (1950), 130-67, repr. as 'Some Agrarian Evidence of Declining Population in the Later Middle Ages', in Michael Postan, Essays on Medieval Agriculture and General Problems of the Medieval Economy (Cambridge: Cambridge University Press, 1973), pp. 186-213; Michael Postan, 'The Economic Foundations of Medieval Society', Jahrbücher für Nationalökonomie 161 (1951), repr. in Postan, Essays, pp. 3-27 (a revised version of his contribution in: Carlo Cipolla, Jan Dhondt, Michael Postan, and Philippe Wolff, 'Rapports collectif', IXe congrès international des sciences historiques, Paris âout - septembre 1950, 1 (1950), 225-41); Michael Postan and Jan Z. Titow, 'Heriots and Prices on Winchester Manors', Economic History Review, 2nd ser., 11: no. 3 (1959), 392-411, repr. in Postan, Essays, pp. 150-85; Michael Postan, 'Medieval Agrarian Society in Its Prime: England', in The Cambridge Economic History, Vol. I: The Agrarian Life of the Middle Ages, $2^{\text {nd }}$ edn., ed. Michael Postan (Cambridge: Cambridge University Press, 1966), pp. 549-632, esp. pp. 560-70; Michael Postan, The Medieval Economy and Society: An Economic History of Britain, 1100-1500 (Cambridge: Cambridge University Press, 1972), pp. 27-40.

${ }^{4}$ Josiah Cox Russell, British Medieval Population (Albequerque: University of New Mexico Press, 1948), pp. 280, 314. Russell had extrapolated evidence from the 1377 Poll Tax to contend that England's population was then 2.235 million, about 40 percent lower than the pre-Plague level of (therefore) 3.7 million.

5 See Postan's publications in n. 3. The direct quotation is from Postan, 'Medieval Society: England', p. 562; the estimate of 6 to 8 million is given subsequently in Medieval Economy, p. 30. Postan's critique was based on Russell's following assumptions about the 1377 poll-tax: that the tax-evasion rate was only 2.5 percent; that the proportion of those under 14 and thus untaxed was 35 percent; that the proper house-hold multiplier was 3.6 persons; and that the post-plague mortality rate was about 40 percent (so that $2.235 / 0.60=3.725$ million). In rebuttal, and thus in providing reasons for estimating the early fourteenthcentury peak population at 6 to 8 million, Postan contended that, in the 1377 Poll Tax, tax evasion was likely as ten times as much, at 25 percent; that the untaxed (under 14) probably accounted for 40-45 percent of the total; that the household multiplier was more likely 4.5 or 5.0; and that total post-Plague mortality was probably 50 percent. Subsequently, J. C. Russell defended his original views in 'The Preplague Population of England', Journal of British Studies, 5:2 (May1966), 1-21, reiterating his contention that England's population had reached a peak of 3.7 million in 1347 (pp. 1, 16, 19, 21) and that 'the decline came only with the plague' (p. 21). But, while stoutly defending his household multiplier of 3.5 - rather than 3.6 (p. 17) - as do many historians -- and while conceding points on tax evasion and those untaxed, he presented a 
population had reached a maximum of about 7.20 million, in the early 1290s; and that after the Great Famine of 1315-22, it had fallen, but to only 6.74 million, so that the most dramatic losses came after the Black Death. ${ }^{6}$ More recently, Bruce Campbell and fellow historians engaged in the 'Feeding the City Project' have contended that a figure of ' 4 million is more credible than one of 4.75 million', for England's maximum population, ca. 1300, a view recently endorsed by Pamela Nightingale. ${ }^{7}$

What then happened, during and after the Great Famine (1315-22) - whose consequences, as we now know, were greatly aggravated by a cattle panzootic ('plague') - is also of considerable dispute. ${ }^{8}$ Postan himself suggested that the Great Famine marked the great watershed, with what was evidently a full blown Malthusian crisis. Certainly he envisaged conditions of overexpansion and thus overpopulation in contending that 'after a time the marginal character of marginal lands was bound to assert itself .. when the poorer lands, no longer new, punished the men who tilled them with failing crops and with murrain of sheep and cattle'. Consequently, 'a fortuitous combination of fortuitous circumstances, such as the succession of bad seasons

revised and even lower population estimate for 1377: 2,199,915 (or 2.2 million; but note that 2.2/0.60 = 3.667 million). Postan never did provide an estimate for the nadir of England's population; but in his 'Medieval Society: England', p. 570, he stated that: 'It is even doubtful whether England's rural population came up to its thirteenth-century peak until the very eve of the industrial revolution of the eighteenth century', when (in 1750), according to current estimates, the population was 5.922 million. See E. A. Wrigley, R.S. Davies, J.E. Oeppen, and R. S. Schofield, English Population History from Family Reconstitution, Cambridge Studies in Population, Economy and Society in Past Time no. 32 (Cambridge and New York: Cambridge University Press, 1997), pp. 613-17.

${ }^{6}$ H. E. Hallam, 'Population Movements in England, 1086-1350', in Agrarian History of England and Wales, vol. II: 1042-1350, ed. H. E. Hallam (Cambridge: Cambridge University Press, 1988), pp. 50893: with statistical summary on p. 536, stating that five out of eight English regions had experienced population decline between 1300 and 1347.

${ }^{7}$ Bruce M.S. Campbell, James A. Galloway, Derek Keene, and Margaret Murphy, A Medieval Capital and Its Grain Supply: Agrarian Production and Distribution in the London Region c. 1300, Historical Geography Research Series no. 30 (London: Institute of British Geographers, 1993), pp. 44-45; Bruce Campbell, English Seigniorial Agriculture, 1250-1450, Cambridge Studies in Historical Geography 31 (Cambridge: Cambridge University Press, 2000), pp. 234, 247-8, 386-410; Pamela Nightingale, 'The Growth of London in the Medieval English Economy', in Progress and Problems in Medieval England, ed. Richard Britnell and John Hatcher (Cambridge : Cambridge University Press, 1996), pp. 89-106.

${ }^{8}$ See William C. Jordan, The Great Famine: Northern Europe in the Early Fourteenth Century (Princeton: Princeton University Press, 1996); Ian Kershaw, 'The Great Famine and Agrarian Crisis in England, 1315-1322', Past and Present, no. 59 (May 1973), pp. 3-50; Timothy P. Newfield, 'A Cattle Panzootic in Early Fourteenth-Century Europe’, British Agricultural History Review, 57:ii (2009), 155-90; Philip Slavin, 'The Fifth Rider of the Apocalypse: The Great Cattle Plague in England and Wales and its Economic Consequences, 1319 - 1350', in Le Interazioni fra economia e ambiente biologico nell'Europa preindustrielle seccoli XIII - XVIII/Economic and Biological Interactions in Pre-Industrial Europe from the $13^{\text {th }}$ to the $18^{\text {th }}$ Centuries, ed. Simonetta Cavaciocchi, Atti delle "Settimana di Studi" e altri convegni, no. 40, Istituto Internazionale di Storia Economica "F. Datini” (Florence: Firenze University Press, 2010), pp. 16579; Bruce M. S. Campbell, 'Nature as Historical Protagonist: Environment and Society in Pre-Industrial England’, The Economic History Review, 63:2 (May 2010), 281-314. 
in the second decade of the fourteenth century, was sufficient to reverse the entire trend of agricultural production and to send the population figures tumbling down'.

Hallam's statistical survey might seem to support that dismal view; but he presents no other data between the aforementioned statistic of 6.74 million in 1317 and 2.75 million in 1377 (yet another estimate), at the time of the first poll tax, not venturing to estimate England's population either on the eve or on the morrow of the Black Death, in 1348-49. ${ }^{10}$ Furthermore, Larry Poos has provided some significant statistical evidence that indicates a decline in Essex's population, following the Great Famine, though with a more precipitous fall after the Black Death. ${ }^{11}$ Bruce Campbell, on the other hand, in his detailed analyses of some parishes in Norfolk to the north also found evidence of an incipient Malthusian crisis on the eve of the Great Famine, in terms of overcrowded subdivided peasant holdings. But he concluded that the population had adjusted to threats of crisis and continued to grow, albeit much more slowly to the eve of the Black Death. ${ }^{12}$ Similar views are also held by Barbara Harvey; ${ }^{13}$ and evidently also by Richard Smith. ${ }^{14}$

If Postan dismissed the view that the Black Death was the true medieval watershed, most historians still see it in that same light. ${ }^{15}$ If, however, we were to accept Hallam's figure of 2.75 million for 1377

9 Postan, 'Economic Foundations', pp. 14-15. Virtually the same words are presented in his 'Agrarian Evidence’, p. 213.

${ }^{10}$ Hallam, 'Population Movements', pp. 508-93.

11 Lawrence Poos, 'The Rural Population of Essex in the Later Middle Ages', Economic History Review, 2nd ser., 38:4 (Nov. 1985), 515-30; Lawrence Poos, A Rural Society after the Black Death: Essex, 1350-1525 (Cambridge: Cambridge University Press, 1991), pp. 89-129, especially Figures 5.21 - 5.2d, on pp. 96-103.

${ }^{12}$ Bruce Campbell, 'Population Pressure, Inheritance, and the Land Market in a Fourteenth-Century Peasant Community', in Land, Kinship and Life-Cycle, ed. Richard Smith (Cambridge: Cambridge University Press, 1984), pp. 87 - 134. See also Mark Bailey, 'Peasant Welfare in England, 1290-1348', Economic History Review, 51:2 (May 1998), 223-517; and n. 52 below.

${ }^{13}$ Barbara Harvey, 'The Population Trend in England Between 1300 and 1348', Transactions of the Royal Historical Society, 5th ser. 16 (1966), 23-42; Barbara Harvey, 'Introduction: the "Crisis” of the Early Fourteenth Century', in Before the Black Death: Studies in the 'Crisis' of the Early Fourteenth Century, ed. Bruce Campbell (Manchester: Manchester University Press, 1991), pp. 1 - 24; Russell, British Medieval Population, pp. 280, 314; Russell, 'Preplague Population', pp. 1-21. See also Anthony Bridbury, 'Before the Black Death', Economic History Review, 2d ser., 30:3 (Aug. 1977), 393-410, suggesting that England was not overpopulated on the eve of the Black Death, thus contradicting views put forth in Anthony Bridbury, 'The Black Death', Economic History Review, 2nd ser., 26:4 (Nov. 1973), 577-92.

${ }^{14}$ Richard Smith, 'Demographic Developments in Rural England, 1300-48: a Survey', in Before the Black Death, ed. Campbell, pp. 25-77: with no definitive conclusion on whether England had suffered a net loss of population between the Great Famine and the Black Death; see also See also John Hatcher, Plague, Population, and the English Economy, 1348-1530 (London: MacMillan, 1977), pp. 11-20.

${ }^{15}$ See the publications of Postan cited above in n. 3. 
(rather than Russell's lower figure of 2.20 million ) and estimate the overall population loss at 50 percent, that would mean that England's population on the eve of the Black Death was 'only' 5.5 million, which is therefore considerably less than his figure for 1317 (6.74 million), but substantially higher than Campbell and Nightingale's estimates for 1300 (4.0 to 4.5 million). ${ }^{16}$ That England's population continued to fall, or rather drift downward through the entire fifteenth century now seems likely, and in all likelihood the turning point did not occur until about the 1520s, when the population of England and Wales can be estimated with some certainty at $2.25-2.30$ million. ${ }^{17}$ That figure, one should note, is only 50 percent of the very conservative estimate of 4.5 million. Unquestionably England, along with most of western Europe, suffered a demographic catastrophe in the later Middle Ages, whether or not it began with the Black Death.

\section{The Postan demographic model on medieval prices: Malthusian and Ricardian foundations}

The major question now becomes: what were the economic and social consequences of such drastic depopulation, which probably involved a decline in the birth rate as well as a rise in the death rate? The Postan model, which so many historians use to answer that question, is essentially Ricardian. Any Ricardian model would predict the following economic consequences (ceteris paribus) of such depopulation: (1) a fall in grain prices, (2) a consequent fall in rents (both landowner's rents and pure economic rent), (3) and a rise

${ }^{16}$ See Edward Miller, 'Introduction: Land and People’, in Agrarian History of England and Wales, Vol. III: 1348-1500, ed. Edward Miller (Cambridge: Cambridge University Press, 1991), pp. 1-33, suggesting a range from 2.5 to 3.0 million in 1377. See also Edward Miller and John Hatcher, Medieval England: Rural Society and Economic Change, 1086-1348, Social and Economic History of England (London: Longman, 1978), pp. 27-63.

${ }^{17}$ For English population estimates in the early 1520s, see Julian Cornwall, 'English Population in the Early Sixteenth Century', Economic History Review, 2nd ser., 23:1 (April 1970), 32-44; Ian Blanchard, 'Population Change, Enclosure, and the Early Tudor Economy', Economic History Review, 2nd ser., 23:3 (Dec. 1970), 427-45; Bruce Campbell, 'The Population of Early Tudor England: A Re-evaluation of the 1522 Muster Returns and the 1524 and 1525 Lay Subsidies', Journal of Historical Geography, 7 (1981), 145-54; Stephen H. Rigby, 'Urban Population in Late Medieval England: the Evidence of the Lay Subsidies', The Economic History Review, 63:2 (May 2010), 393-417 (with some critical comments on these earlier population estimates). For studies on English demography, indicating either demographic stagnation or further decline to the early sixteenth century, see sources cited nn. 10-16, and also John Hatcher, 'Mortality in the Fifteenth Century: Some New Evidence', Economic History Review, 2nd ser. 39:1 (Feb. 1986), 19-38; John Hatcher, 'England in the Aftermath of the Black Death', Past \& Present, no. 144 (1994), pp. 3-35; John Hatcher, A. J. Piper, and David Stone, 'Monastic Mortality: Durham Priory, 1395 - 1539', The Economic History Review, 59:4 (November 2006), 667-687; Pamela Nightingale, 'Some New Evidence of Crises and Trends of Mortality in Late Medieval England', Past and Present, no. 187 (May 2005), pp. 33-68; Lawrence R. Poos, 'The Historical Demography of Northern Europe, 1400 - 1650', in New Approaches to the History of Late Medieval and Early Modern Europe: Selected Proceedings of Two International Conferences at the Royal Danish Academy of Sciences and Letters in Copenhagen in 1997 and 1999, ed. Troels Dohlerup and Per Ingesman (Copenhagen: The Royal Danish Academy of Sciences and Letters, 2009), pp. 365-96; Andrew Hinde, England's Population: A History Since the Domesday Survey (London: Hodder Arnold, 2003). 
in real wages (as defined later in this study). ${ }^{18}$

This model is also based on the views of the English Classical economist Thomas Malthus (17761834). In essence, Malthus contended that population growth, if left unchecked by 'providential' and 'prudential' constraints, would tend to grow exponentially, while the food supply, at best, could increase only by arithmetical, incremental, additions. The inevitable result would thus be falling real incomes, increasing impoverishment for the masses, a rising death toll from malnutrition and disease, and then a falling population, until a new equilibrium was established. Malthus himself, however, believed that, in a developed society, 'prudential' constraints - what we would now call the European Marriage Pattern - would check the growth in population, before the 'providential' forces of famine, disease, and war became necessary. ${ }^{19}$

Subsequently, the 'marginal utility' school combined these concepts into the Law of Diminishing Returns. It specifies that if increased units of labour are applied to a fixed stock of land and capital, with an unvarying technology, the extra or marginal output from each added unit of labour will increase to a maximum point of efficiency, beyond which any extra labour units will produce smaller and smaller marginal outputs. Note that both total and average output will continue to increase, in the 'short run', so that the declining marginal product curve will intersect the rising average product curve at its peak; and thus both the marginal and average product curves must decline to a very considerable extent before any signs of a genuine 'Malthusian' crisis would be manifested.

The seemingly complex Postan model can thus be more readily understood in the light of these theoretical considerations. The model's basic supposition is that the marginal productivity of agrarian labour rose as the direct consequence of the radical alteration in the land:labour ratio that, in turn, had been the consequence of late-medieval depopulation. In a fundamentally agrarian economy, such changes presumably would have taken place fairly quickly, with the abandonment of many high-cost marginal lands, which,

${ }^{18}$ Note that David Ricardo (1772 - 1823) was the Classical Economist who correctly demonstrated that prices - prices for arable and livestock products of land - determine the rent, and not the other way around. David Ricardo, Principles of Political Economy and Taxation, with an introduction by Donald Wench [London, 1817] (London: Dent, 1982).

${ }^{19}$ Robert Thomas Malthus, An Essay on the Principles of Population, $1^{\text {st }}$ edn. [London, 1798] (Oxford and New York: Oxford University Press, 1993); Robert Thomas Malthus, Principles of Political Economy: Considered With a View to Their Practical Application, $2^{\text {nd }}$ edn. [London, 1836] (New York: A. M. Kelly, 1968). See also John Hajnal, 'European Marriage Patterns in Perspective', in Population in History: Essays in Historical Demography, ed. David V. Glass and D.E.C. Eversley (London: E. Arnold, 1965), pp. 101-46; Tine de Moor and Jan Luiten Van Zanden, 'Girl Power: the European Marriage Pattern and Labour Markets in the North Sea Region in the Late Medieval and Early Modern Period', The Economic History Review, 63:1 (February 2010), 1-33; James Foreman-Peck, 'The Western European Marriage Pattern and Economic Development’, Explorations in Economic History, 48:2 (April 2011), 292-309. 
because of extensive prior population growth, had been subject to severely diminishing returns. Thus arable husbandry would subsequently - after some delays in adjustments - have become concentrated on much better quality, higher-yielding lands that produced much more grain and livestock products with proportionately less labour, at much lower cost. ${ }^{20}$

One would then predict that grain prices would have fallen, relative to other prices, for three reasons. First, the marginal cost of producing a bushel of grain would have decreased, for the reasons just stated. Second, the lower-cost lands on which that grain was then being produced were presumably closer to markets, so that average transportation costs would also have fallen. Third, the reduction in the quantity of grain supplied to the market probably would have less than the decline in population , if only because some redundant but still good lands would have remained in production.

We would further assume, as a consequence of these changes, that real wages of agricultural labourers would have risen, for basically three reasons. First, according to Classical Economics, the real wage is determined by the marginal productivity of labour; and thus the drastically altered land:labour ratio should have led to a substantial rise in the marginal productivity of labour. Indeed, as Bridbury suggested some time ago, the original impact of Black Death would have been the 'purgative' elimination of disguised unemployment on overcrowded lands. ${ }^{21}$ As the Law of Diminishing Returns indicates, the removal units of labour (from a fixed stock of land and capital) would necessarily have increased its marginal product, to that point of maximum efficiency. Second, we may assume that, over time, the supply of available labour to work lands in production became even scarcer, as former itinerant labourers either took up vacated tenancies or sought employment at higher wages in the towns or in the now expanding rural cloth industry. ${ }^{22}$ Third, these agrarian changes themselves would have led to a rise in real wages by reducing the prices of foodstuffs and the cost of living in general, including housing costs, with so much more available land. The term 'real wage' means, after all, the quantity of goods and services that can be purchased with the daily, weekly, or annual money wage (plus any additional material benefits supplied by the employer).

${ }^{20}$ On the abandonment of land in so much of medieval western Europe, see the sources cited above in n. 2.

${ }^{21}$ Bridbury, 'Black Death', pp. 577-92: but he subsequently contradicted this thesis in 'Before the Black Death’, pp. 393-13. See comments in n. 13 above.

${ }^{22}$ On this point, see Postan, 'Agrarian Evidence', p. 211; and other publications cited in n. 3. But, while accepting the impact of a two-fold depletion, as former labourers took up depleted holdings, he rejected the view that the expanding cloth industry, still so small in scale, affected the supply of agricultural labour. 
Classical economic theory further assumes that any such rise in real wages in the agrarian sector would necessarily have been transmitted to other sectors, especially the towns, lest the latter lose labour to the agrarian sector. The tables in this study do indicate that English rural and urban wages followed basically the same trends. Such a process would presumably have been facilitated by the increased labour mobility that ensued from the later fourteenth century, with the breakdown of the manorial domain economies, the consequent leasing of domain lands to peasant tenants, and the decay of villeinage (serfdom). ${ }^{23}$

These changes would in turn have led to further changes in relative commodity prices, producing a widening divergence between falling grain prices and rising prices for livestock products and industrial goods. Thus, labourers and artisans, in both rural and urban areas, on finding that they were enjoying greater disposable real incomes, after meeting the basic necessities of life, would probably have chosen to increase their spending on meat, dairy products, industrial goods, and semi-luxuries, thus driving up the relative prices of such goods. Prices for manufactured goods should have risen even more, because the continued rise in industrial wages would have accounted for an even greater share of total production costs than did the wages spent in producing grain and livestock products. Such is the classic demographic model for the late-medieval English and indeed West European economy, one that certainly seems both plausible and reasonable in its delineation of expected changes in relative prices, including that of labour (i.e., in real wages).

\section{Postan on money and prices in the late-medieval economy}

As already indicated, Postan's Ricardo-based demographic model does not permit any role for monetary factors. Contending that the fall in prices was almost entirely confined to grains, so that they diverged from other prices, Postan argued that 'monetary factors could not have been the sole or the main cause of the price changes, for the pure logic of the monetary explanation demands that the effects of changes in the circulating medium should be felt throughout the economy'; in other words, the role of money had to

${ }^{23}$ See Rodney H. Hilton, The Decline of Serfdom in Medieval England, Studies in Economic History series, 2nd rev. edn. (London: MacMillan, 1983); Ambrose Raftis, Tenure and Mobility: Studies in the Social History of the Medieval English Village (Toronto: Pontifical Institute of Mediaeval Studies, 1964), pp. 129-204; Ambrose Raftis, 'Peasants and the Collapse of the Manorial Economy on Some Ramsey Abbey Estates', in Progress and Problems, ed. Britnell and Hatcher, pp. 191-206; David Farmer, 'The Famuli in the Later Middle Ages', also in Progress and Problems, pp. 214-20; Hatcher, 'England in the Aftermath', pp. 3-35; John Munro, 'The Late-Medieval Decline of English Demesne Agriculture: Demographic, Monetary, and Political-Fiscal Factors', in Town and Countryside in the Age of the Black Death: Essays in Honour of John Hatcher, ed. Mark Bailey and Stephen Rigby, The Medieval Countryside, vol. 12 (Turnhout: Brepols, 2012), pp. 299-348. 
be 'neutral' ${ }^{24}$ In like fashion, he also argued that a 'fall in population would also have, so to speak, a selective effect on prices, in that it would tend to lower the prices of agricultural products, which were previously being produced at high and every rising cost under steeply diminishing returns'; but falling population would have had ' little effect on commodities not greatly subject to diminishing returns, i.e., most industrial products'. ${ }^{25}$

Postan's primary contention, that all prices must move together in unison during periods of inflation or deflation, is simply a fallacy, which will be refuted by all the price tables in this study. ${ }^{26}$ His view neglects the historical reality that, during long periods of major monetary changes, a combination of changes in various real factors (population, technology, capital investments, etc.) were always acting to alter the relative prices of many or most individual commodities. Second, monetary changes are never 'neutral'. For example, distributions of increased stocks of money, with regional variations, would have benefited some economic sectors more than others, thus allowing some groups or socio-economic strata to achieve relatively greater increases in money incomes. The consequent changes in their savings and expenditure patterns would also have altered the relative prices of a wide variety of individual goods and services through their impact on the price- and income-elasticities of demand for various commodities and also their elasticities of supply. Furthermore, to the extent that such increases in money supplies produced inflation, those with relatively fixed incomes would have faced budget constraints, forcing them to spend proportionately more on necessities (foodstuffs and fuels) and thus less on luxuries (most industrial goods), with a similar impact on relative prices. For monetary contractions, we may simply reverse the roles of the variables in this model.

\section{The evidence on late-medieval prices and wages}

To test the validity of Postan's Ricardo-based economic model, and its rejection of monetary factors, we need statistical evidence to substantiate the three aforementioned propositions for the post-Plague era: (1) that grain prices fell, relative to other commodity prices; (2) that the marginal productivity of agricultural labour rose; and (3) that the real wages and total incomes of agricultural and other labourers and craftsmen rose. In brief, the now available statistical evidence does not support Postan's model on prices and wages,

${ }^{24}$ The first quotation is from Postan, Medieval Economy, p. 239; the others are from Postan, 'Trade of Medieval Europe’, pp. 213, 209-10, respectively (sources cited in n. 1 above). See also the appendix.

${ }^{25}$ Postan, ‘Trade of Medieval Europe’, p. 214.

${ }^{26}$ See this specific criticism in Anna Jacobson Schwartz, 'Review', Journal of European Economic History, 3:1 (Spring 1974), 252-55: a review of Frank Spooner, International Economy and Monetary Movements in France, 1493 - 1725 (Cambridge, Mass.: Harvard University Press, 1972). 
either before or after the Black Death.

In fairness to Postan, however, we must note that few continuous series of medieval prices and wages were available in the early 1950s, when his principal publications appeared. ${ }^{27}$ Even today, only later medieval England and the Low Countries are well served by reliable and continuous consumer price-index series. The famous Phelps Brown and Hopkins 'basket of consumables' price index for England itself was not published until 1956, and then only as a composite index. Furthermore, its crucially important component price-index series - for grains, meat, fish, dairy products, drink, fuel and light, and textiles -- were not published until much later, in 1981, the very year that Postan died. ${ }^{28}$ Between those dates, in 1975, Herman Van der Wee published a similar 'basket of consumables' price index for the Antwerp-Lier-Brussels region of Brabant, from 1400 to $1700 .^{29}$ Much more recently, I myself have constructed a similar component priceindex, based on both the well known Phelps Brown \& Hopkins and the Van der Wee indexes, for Flanders (Ghent-Bruges region), from 1351-1500; and I have also recently revised the Phelps Brown \& Hopkins price index, from their original working papers now stored in the LSE Archives.

The Van der Wee price index for Brabant, the Munro price index for Flanders, and the newly revised Phelps Brown and Hopkins (PBH) price index for England all differ from the original Phelps Brown \& Hopkins model in one crucial respect. While the original PBH index had provided prices only in annual index numbers, the other three provide both annual index numbers and the actual total value of each commodity group and of the 'basket of consumables' in the local money of account (pence sterling and groot). The significance of that difference is two-fold. First, while the component weights of the PBH index are rigidly fixed through time, the component weights of the other indexes fluctuate with changes in relative prices.

${ }^{27}$ For Postan’s publications, see n. 3 above.

${ }^{28}$ E. Henry Phelps Brown and Sheila V. Hopkins, 'Seven Centuries of the Prices of Consumables, Compared with Builders' Wage Rates', Economica, 23:92 (November 1956), 296-314: reprinted in E.H. Phelps Brown and Sheila V. Hopkins, A Perspective of Wages and Prices (London: Methuen, 1981), pp. 1339 (with price indexes not in the original). A recent alternative set of agricultural prices (not used in this study) is presented in Gregory Clark, 'The Price History of English Agriculture, 1209 - 1914', Research in Economic History, 22 (2004), 125-81.

${ }^{29}$ Herman Van der Wee, 'Prijzen en lonen als ontwikkelingsvariabelen: Een vergelijkend onderzoek tussen Engeland en de Zuidelijke Nederlanden, 1400-1700', in Album aangeboden aan Charles Verlinden ter gelegenheid van zijn dertig jaar professoraat (Wetteren: Universum, 1975), pp. 413-47; reissued in English translation as 'Prices and Wages as Development Variables: A Comparison Between England and the Southern Netherlands, 1400-1700', Acta Historiae Neerlandicae, 10 (1978), 58-78; republished in Herman Van der Wee, The Low Countries in the Early Modern World, trans. by Lizabeth Fackelman (Cambridge and New York: Cambridge University Press and Variorum, 1993), pp. 223-41. Only the original Dutch-language version contains the statistical numerical tables. 
Second, since all three baskets are roughly comparable in their composition, we may better compare levels of real wages between the countries concerned.

\section{The behaviour of prices in late-medieval England and Flanders}

The statistical results for late-medieval commodity prices in both England and Flanders are presented, though only in quinquennial means, in Tables $1-5 .^{30}$ All the tables, for both commodity prices and wages (Tables 6 - 12) have the same common index base: the mean values of 1451-75 $=100$, the one that Phelps Brown and Hopkins established: ‘chosen because it lies within a long period of stability.... ${ }^{31}$ Thus the price and wage indexes in all these tables are really percentages of the values for that base period. T h e s e tables, along with Figures 1 and 2, clearly demonstrate an oscillating series of inflations and deflations, from the late thirteenth to the early sixteenth century: that is, inflation from the 1270s to the 1320s (after the Great Famine); deflation from the mid 1320s to the late 1340s - to the eve of the Black Death; a severe inflation following the Black Death, lasting to the 1370s in England, and to the late 1380s in Flanders; then very a severe deflation in both countries until 1420s; then inflation for both during the next twenty years, until the early 1440s; then more severe deflation lasting until the 1470s, followed by inflation until the 1490s, in turn followed by deflation until just after 1510, i.e, to the eve of the sixteenth-century Price Revolution (which lies beyond the scope of this study).

The most striking feature of these tables is the very severe inflation that followed the Black Death, in both England and Flanders. In England (Tables 1-2), the quarter century preceding the Plague had been one of deflation, during which the Consumer Price Index (CPI) had fallen from a quinquennial mean of 130.704 in 1321-25 to a nadir of 85.533 in 1341-45: a stark decline of 34.56 percent. ${ }^{32}$ Thereafter, the CPI

${ }^{30}$ See the sources for these tables. Earlier versions of the Flemish commodity-price tables (quinquennial means only) were published in John Munro, 'Wage Stickiness, Monetary Changes, and Real Incomes in Late-Medieval England and the Low Countries, 1300 - 1500: Did Money Matter?' Research in Economic History, 21 (2003), 185 - 297 (Table 8, pp. 249-50); and John Munro, 'Builders' Wages in Southern England and the Southern Low Countries, 1346 -1500: A Comparative Study of Trends in and Levels of Real Incomes', in L'Edilizia prima della rivoluzione industriale, secoli XIII-XVIII, ed. Simonetta Cavaciocchi, Atti delle "Settimana di Studi" e altri convegni, no. 36, Istituto Internazionale di Storia Economica F. Datini (Florence: Le Monnier, 2005), pp. 1013-76 (Tables 3-4, pp. 1054-55). For the fourteenth century English prices and wages, see also: John Munro, 'Before and After the Black Death: Money, Prices, and Wages in Fourteenth-Century England', in New Approaches to the History of Late Medieval and Early Modern Europe: Selected Proceedings of Two International Conferences at The Royal Danish Academy of Sciences and Letters in Copenhagen in 1997 and 1999, ed. Troels Dahlerup and Per Ingesman (Copenhagen: The Royal Danish Academy of Sciences and Letters, 2009), pp. 335-364.

${ }^{31}$ Phelps Brown and Hopkins, ‘Prices of Consumables’, p. 305.

${ }^{32}$ Because of the fortuitous supply shocks of the preceding Great Famine era, measuring the decline from the peak CPI of 154.560 in 1316-20 would be very inappropriate. See n. 8 above. 
rose to a peak of 137.976 in 1361-65, an even more dramatic increase of 61.31 percent (37.89 percent, from 1346-50). The CPI remained at virtually that high level in 1366-70 (136.460); and in 1371-75 it was still elevated well beyond the long-term trend, at 127.345.

Such post-Plague inflation may also be found in Flanders, though we lack sufficient price data before 1350. As Tables 3-4 indicate, for the post-Plague era, the Flemish CPI rose even more strongly, more than doubled: from a mean of 60.646 in 1351-55 to reach a much later peak of 124.719 in 1386-90, a rise of 105.65 percent (but 55.70 percent, from 1351-55 to 1361-65). One fundamental monetary difference between the two countries must be noted here: that Flanders experienced far many more and more severe coinage debasements than did England. Thus, while the Flemish silver coinage was debased nineteen times between 1351 and 1388 (inclusive), reducing the groot's fine metal content from 2.067 grams to 0.781 grams, for an overall loss of 62.22 percent, the English sterling silver coinage was debased only once in this era, in 1351, and only by 10.00 percent (from $1.199 \mathrm{~g}$ to $1.079 \mathrm{~g}$ ). ${ }^{33}$ Debasement, however, was hardly the only factor responsible for these inflations (and the least important, for England), whose more complete explanations must await the final section of this study. ${ }^{34}$

As Tables 1 - 4 also indicates, the prices of all commodities in these price 'baskets' all rose together (and later, all fell together): and that it is the proper measure of inflation. These component price indices did not, however, rise together in tandem; and the differences, reflecting the operation of real force on relative commodity prices, are themselves very instructive in evaluating the Postan thesis. ${ }^{35}$ Thus, for the twenty years of inflation that followed the Black Death, the increase in grain prices (wheat, rye, barley, peas, malt) well exceeded the price increases for the meat-fish-dairy products and industrial products (textiles, fuels)

${ }^{33}$ See John Munro, 'Mint Policies, Ratios, and Outputs in England and the Low Countries, 1335-1420: Some Reflections on New Data', The Numismatic Chronicle, 141 (1981), 71-116; John Munro, 'Bullion Flows and Monetary Contraction in Late-Medieval England and the Low Countries', in Precious Metals in the Later Medieval and Early Modern Worlds, ed. John F. Richards (Durham: Carolina Academic Press, 1983), pp. 97-158; John Munro, 'Deflation and the Petty Coinage Problem in the Late-Medieval Economy: The Case of Flanders, 1334 - 1484', Explorations in Economic History, 25 (October 1988), 387423; and other studies in John Munro, Bullion Flows and Monetary Policies in England and the Low Countries, 1350-1500 (Aldershot: Variorum Ashgate, 1992). See 'My Statistical Tables on Medieval and Early Modern Money and Coinage’: http://www.economics.utoronto.ca/munro5/ResearchData.html

${ }^{34}$ See pp. 35-39 below. There is no direct correlation between debasement and inflation, as I have sought to demonstrate in John Munro, 'The Technology and Economics of Coinage Debasements in Medieval and Early Modern Europe: with Special Reference to the Low Countries and England', in Money in the Pre-Industrial World: Bullion, Debasements and Coin Substitutes, ed. John Munro, Financial History Series no. 20 (London: Pickering \& Chatto Ltd., 2012), pp. 15-32, 185-89 (endnotes).

${ }^{35}$ As Table 5 indicates, foodstuffs collectively accounted for about 80 percent of the commodity price-weights in both the English and Flemish commodity-price baskets. 
categories. In England, from 1341-45 to 1371-75, prices for grains (wheat, rye, barley, peas) rose by 43.20 percent; for meat-fish-dairy products, by 28.60 percent; and those for industrial products, by 35.05 percent. Similarly, in Flanders, from 1351-55 to 1366-70, grain prices rose by 85.54 percent (93.88 percent, by 138690), while dairy-product prices rose by a lesser degree, by 61.50 percent (94.54 percent by 1386-90). In contrast to the English experience, however, Flemish industrial prices rose as much as did grain prices: by 88.79 percent, by $1366-70$ (185.47 percent by 1386-90). Since Flanders' industrial prices in this index are for textiles alone, that price rise may reflect the peculiar and harsh difficulties - 'supply shocks' - that afflicted the Flemish woollens industry from the mid-fourteenth century. ${ }^{36}$

The rather different English experience fits the classic budget-constraint model much better, indicating that most lower-class wage-earning families were forced to spend proportionately more of their limited money incomes on bread grains, and thus proportionately less on meat, fish, dairy products and industrial goods (except fuels). Such an expenditure shift in England can be seen in Table 1 (columns 7-9); and that shift would have limited the increases in non-grain commodity prices during this inflationary era.

The most important observations to be derived from these price tables are that, in stark contrast to the Ricardo-based Postan model, grain prices in both nominal and real terms rose - not fell - after the Black Death; and furthermore, that the demographic factors can hardly have been responsible for these sets of price changes. Subsequently, from the later 1370s in England and from the early 1390s in Flanders, grain prices did fall, but so did other commodity prices, though again not in tandem. To contend that the Black Death and depopulation took more than a quarter of a century to bring about this fall in prices strains one's credulity. The explanation for those subsequent changes in commodity prices, continuing into the fifteenth century, must again await the final section of this study.

\section{The evidence on late-medieval English wages: nominal and real}

The importance of these changes in commodity prices for real wages is clearly evident from the very formula so widely used to measure changes in real wages: RWI = NWI/CPI, necessarily using index numbers. Thus dividing the nominal or money wage index (in silver pence) by the consumer price index produces the

\footnotetext{
${ }^{36}$ The chief problems were the steep increases in the prices of English wools on which the Flemish industry depended and civil strife in the Flemish textiles towns. See John Munro, 'The Symbiosis of Towns and Textiles: Urban Institutions and the Changing Fortunes of Cloth Manufacturing in the Low Countries and England, 1270 - 1570', The Journal of Early Modern History: Contacts, Comparisons, Contrasts, 3:1 (February 1999), 1-74; John Munro, 'Medieval Woollens: The Western European Woollen Industries and their Struggles for International Markets, c.1000 - 1500', in The Cambridge History of Western Textiles, 2 vols., ed. David Jenkins, (Cambridge and New York: Cambridge University Press, 2003), Vol. I, chapter 5, pp. 228-324, 378-86 (bibliography).
} 
real wage index. Other conceptions and measures of real wages will be considered as the next major topic in this study.

Though Postan and so many of his followers have long contended that real wages experienced a sustained rise in the fourteenth century - from the Great Famine, according to Postan, and from at least the Black Death, according to his followers - the evidence contradicts that view, even in the evidence published long before Postan’s initial articles. First, as Lord William Beveridge had noted (in 1936), nominal wages on many Winchester manors, having begun to rise from 1362-63 - though well after the Black Death, were forced down in 1367-68, evidently at the behest of the new Bishop William of Wykeham; but then the higher money rates were restored between 1370 and 1375. Only thereafter - almost thirty years after the Black Death - did their real wages enjoy a sustained rise (as indicated by Table 4). ${ }^{37}$ The manorial records of Taunton (Somerset) provide the most striking if admittedly unusual deviation from the presumed norm in the behaviour of labourer's wages in the later fourteenth-century. To be sure, after the onslaught of the Black Death, casual farm-labourers on the Taunton manor had enjoyed a doubling in their money wages, with a substantial increase as well in their real wage, from 1349 to 1356 . Thereafter, however, both their money and real wages fell, and from 1362-63 (i.e., before the election of Bishop William) they fell sharply to pre-Plague levels - even in nominal money terms. Their real wages fell even more steeply below such levels, recovering only from 1378; but their money wages did not recover before $1412-13 .^{38}$

As Beveridge has also shown, however, piece-work money wages for seasonal harvest workers on eight Winchester manors did rise substantially over the thirty-year period from 1340-9 to 1360-9, especially for threshers and winnowers: by an average of 21.27 percent (in decennial means). ${ }^{39}$ But, as already shown, the English consumer price index, with the previously highlighted post-Plague inflation, rose by 48.14 percent

37 William Beveridge, 'Wages in the Winchester Manors', Economic History Review, 1st ser., 7:1 (Nov. 1936), 22-43. See also William Beveridge, 'Westminster Wages in the Manorial Era', Economic History Review, 2nd ser., 8:1 (1955), 18 - 35.

${ }^{38}$ See Munro, 'Wage Stickiness', Table 7, pp. 245-48. I have not, however, found any other comparable examples in manorial accounts whose data are preserved in: Archives, British Library of Economic and Political Science, Beveridge Price and Wage History Collection, Boxes A 31-32. Beveridge, 'Winchester Manors', p. 30, commented that wages in the Taunton manor 'are affected by the greater importance there of customary services and the best method of presenting the [wage] series has not been determined.' But that does not satisfactorily explain why building wages at Taunton were generally higher before the Black Death than elsewhere. Yet if Beveridge was correct, then wages on many late-medieval English manors would have been - to a greater or lesser degree - affected by the relative supplies of servile labour, before and after the Black Death.

${ }^{39}$ Beveridge, 'Winchester Manors', pp. 22-43: from a mean of 5.03d per quarter of grain (= 8 bushels) to one of $6.10 \mathrm{~d}$ per quarter. See the next note. 
over these three decades, so that 'real wages' had correspondingly fallen very substantially - not risen, as so commonly and wrongly assumed - after the Black Death! ${ }^{40}$

A far more comprehensive set of supposedly 'national' agricultural wages was published by the late David Farmer, between 1983 and 1991. ${ }^{41}$ There are many serious problems with his statistics. Obviously, for a country as regionally diverse as medieval England, the concept of 'national' wages is an absurdity. Furthermore, calculations of these annual wages suffer from two likely 'compositional' errors that likely distort their values, in producing spurious annual fluctuations. The first is the periodic absence of wage data from higher and/or lower wage regions; and second is the periodic absence of higher and lower paid wageearners in each occupation (agricultural and industrial) recorded, for each manorial location. ${ }^{42}$ These problems become especially acute from the 1420s, when, after four decades of leasing, very few manorial demesne accounts remain - possibly only those for the most profitable demesnes, with (possibly) the highest wages. ${ }^{43}$ Furthermore, the purely agricultural wages are for piece-work tasks, for seasonal workers, so that we have no way of estimating their annual money-wage incomes. We also cannot be absolutely certain that the payments for these tasks were in money (silver pence) alone, without supplementary payments in kind.

With these important caveats in mind, we may examine the wage data presented in Tables 6-8, in which Farmer's annual data have been converted from his index numbers into silver pence. I have also computed quinquennial means of those wages, and of the nominal and real wage indexes, adding as well my revised version of the Phelps Brown \& Hopkins consumer price index (from Tables 1-2, 5). ${ }^{44}$ For threshers

${ }^{40}$ This calculation is based on combining the quinquennial means for the 1340 s and the 1370 s, in Tables 1-2 (for prices), to produce decennial means. The rate of inflation from the quinquennium 1341-45 to 1366-70 was even greater: 59.54 percent. The comparisons are not fully accurate, since Beveridge used decennial means commencing in year zero (or ten) and ending in nine (1340-49), while these tables commence the decade in year one and end them in year ten (1341-50).

41 David Farmer, 'Crop Yields, Prices and Wages in Medieval England', Studies in Medieval and Renaissance History, old series, 6 (1983), 117-55; David Farmer, 'Prices and Wages', in The Agrarian History of England and Wales, Vol. II: 1042-1350, ed. H. E. Hallam (Cambridge: Cambridge University Press, 1988), pp. 760-78, 811-17; David Farmer, 'Prices and Wages, 1350-1500', in The Agrarian History of England and Wales, Vol. III: 1348-1500, ed. Edward Miller (Cambridge: Cambridge University Press, 1991), pp. 467-90, 516-24.

${ }^{42}$ A more detailed analysis of such compositional errors is presented in Munro, 'Wage Stickiness', pp. 196-97.

${ }^{43}$ See Munro, 'Late-Medieval Decline’, pp. 299-348.

${ }^{44}$ For the use of harmonic rather than arithmetic means, see F. C. Mills, Introduction to Statistics (New York: Henry Holt, 1956), pp. 108-12, 401; and Munro, 'Wage Stickiness', p. 278, n. 83; and especially Munro, 'Builders' Wages', p.1028 and n. 40. 
and winnowers, during this same period, these data also show a very similar increase in nominal money wages: of 23.51 percent, from 1341-45 to 1366-70; but a much sharper rise of 36.58 percent for reapers and mowers. Once again, however, these data also demonstrate that the post-Plague inflation inflicted a dismal loss in real wages: a decline of 23.56 percent for threshers and winnowers and a lesser one of 14.73 percent for reapers and mowers. The changes were fundamentally if not totally the same for the manorial wages of industrial workers in Farmer's 'national’ series, as tabulated in Tables 7-8. The nominal money wages for carpenters rose, over these three decades, by 44.47 percent; those for tilers and slaters, by almost the same, 45.30 percent; those for thatchers, by even more, 60.00 percent. But similarly, over this period, the inflationravaged real wages for manorial carpenters fell by 5.67 percent; those for slaters and tilers, by much more, 15.40 percent; but those for thatchers remained virtually the same (a minuscule gain of 0.52 percent), perhaps reflecting their very large gain in nominal wages.

While our focus is on agrarian society, we may still usefully compare these results with those that Henry Phelps Brown and Sheila Hopkins had earlier produced for urban industrial craftsmen - carpenters and masons. ${ }^{45}$ Their wage series, presented in Tables 9 (for masters) and 10 (for journeymen labourers) are more useful than those of Farmer, because these two authors (PB\&H) had carefully avoided the previously discussed 'compositional’ problems. First, they selected just the prevalent or predominant daily wages, in money alone (excluding all payments in kind), without computing mean wages for those employed on each work site. Second, they drew their evidence from one common regional source: chiefly the building accounts of Oxford, Cambridge, and some other small towns in SE England (but excluding London). ${ }^{46}$ These tables also have the added advantage of presenting real wages in a method that avoids commonly cited problems

${ }^{45}$ See also: Gregory Clark, 'The Long March of History: Farm Wages, Population, and Economic Growth: England, 1209-1869', The Economic History Review, $2^{\text {nd }}$ ser., 60:1 (February 2007), 97-135; and also Gregory Clark, 'Work, Wages and Living Conditions: Building Workers in England from Magna Carta to Tony Blair', in L'Edilizia prima della rivoluzione industriale, secc. XIII-XVIII, ed. Simonetta Caviococchi, Atti delle "Settimana di Studi" e altri convegni, no. 36, Istituto Internazionale di Storia Economica "F. Datini” (Florence: Le Monnier, 2005), pp. 889-932; Gregory Clark, 'The Condition of the Working Class in England, 1209-2004', Journal of Political Economy, 113:6 (December 2005), 1307-1340. I found his 'national' wage series to be unusable for this study, for reasons set forth in Munro, 'Late Medieval Decline', p. 311, n. 17: especially his use of regression analysis to convert piece-work rates into daily wages.

${ }^{46}$ See E. Henry Phelps Brown and Sheila V. Hopkins, 'Seven Centuries of Building Wages', Economica, 22:87 (August 1955), 195-206, reprinted in Henry Phelps Brown and Sheila Hopkins, A Perspective of Wages and Prices (London: Methuen, 1981), pp. 1- 12. Their primary published source was James E. Thorold Rogers, A History of Agriculture and Prices in England From the Year After the Oxford Parliament (1259) to the Commencement of the Continental War (1793), 7 vols. (Oxford: Clarendon Press, 1866 - 1902), in which the raw price and wage data are presented in Vol. I: 1259-1400 (1866) and Vol. IV (1401-1582) (1887). 
with index numbers: in the number of 'baskets of consumables' that a master craftsmen and labourer could have bought with their annual money wage income, based on a year of 210 days employment. ${ }^{47}$ The aggregate annual mean values of those baskets, in pence sterling, are also presented in Table $1 .^{48}$

From the much longer perspective, beginning in the 1260s, we find that nominal money wage remained perfectly stable until the beginning of the fourteenth century (at 3d per day), and then rose, by a third to peak in the mid 1330s (at 4d per day), and then fell back to the late thirteenth-century level (3d), remaining there until the eve of the Black Death. Real wages also experienced a rise in the early fourteenthcentury, except obviously during the Great Famine era, and peaked during the deflationary era from ca. 1325 to ca. 1345, despite the fall in nominal wages (reflecting that deflation). From its peak in 1336-40, the Real Wage Index (RWI) of 66.986 fell sharply in the aftermath of the Black Death: by 30.51 percent, from 66.986 to 46.552 in , in 1351-55 (from 7.482 commodity baskets to 5.200 baskets). Real wages then recovered, but even as late as 1371-75 $(\mathrm{RWI}=65.439)$, they were still slightly below that earlier peak. Only from the late 1370s - again three decades after the Black Death - did these urban craftsmen experience a sustained rise in their real wages, for reasons to be seen later in this study (see below, pp. 28-9)

Tables 5 - 7 demonstrate a similar pattern of real-wage changes in the English countryside. Thus, according to Farmer's data on 'national' manorial wages for reapers and binders, their RWI similarly fell from their pre-Plague peak of 71.277 in 1341-45 to a post-Plague low of 55.741 in 1356-60, after which they began to recover and finally enjoy a sustained rise (as will also be seen later). The RWI for threshers and winnowers also fell from the pre-Plague peek of 60.912 in 1341-45 to a nadir of 43.542 in 1361-65, thereafter enjoying a rather less impressive recovery The experience of manorial craftsmen in Farmers' series (Tables 7-8) lay between those of the urban craftsmen (Table 9) and the manorial agricultural labourers (Table 6). The manorial carpenters similarly suffered a decline in real wages: falling from the pre-Plague peak of 63.364 in 1341-45 to a low of 50.181 in 1351-55, thereafter recovering but not exceeding the pre-Plague peak until 1376-80. Somewhat if not fundamentally different was the experience of the slaters and tilers. Their RWI, falling from the pre-Plague peak of 59.248 in 1336-40 to a post-Plague nadir of 48.544 as late as 1361-65, similarly surpassed the pre-Plague peak only in the late 1370s (Table 7).

${ }^{47}$ For the complex reasons justifying this estimate of 210 days employment per year in the medieval building trades, see Munro, 'Wage Stickiness', pp. 201-02, and n. 40 (p. 274); Munro, 'Builders' Wages', pp. 1028-29 and nn. 41-45.

${ }^{48}$ Table 2 repeats the aggregate 'basket' index numbers in column 9, while column 10 presents, for comparison, Phelps Brown \& Hopkins' original index numbers. 


\section{The evidence on late-medieval Flemish wages: nominal and real}

For Flanders, we have in this study a wage series only for urban industrial workers - i.e., no agricultural or other rural data, and wage data only for Bruges: presented in Table 11, for master building craftsmen, and Table 12, for their journeymen labourers. These tables also present estimate of annual moneywage incomes expressed in terms of commodity baskets. Before analysing the wage trends, we may first note two contrasts with the English urban wage data, in Tables 9-10. First, at the beginning of the Flemish series, in 1351-55, the Bruges master building craftsmen’s mean real wage income was 172.85 percent greater than that for their English counterparts (Table 9): 14.188 baskets vs. 5.200 baskets; but when the series ends, in 1481-85, the real-wage incomes for the Bruges master craftsmen was in fact much lower than in 1351-55, and only 26.67 percent higher than the English craftsmen's wages in 1481-85(11.661 baskets vs. 9.202 baskets). ${ }^{49}$ The second difference concerns the daily labourers in both countries. In England, their wages rose from the long-traditional one-half of their master's nominal wages, after the Black Death, rising to two thirds of the masters' wages by 1411-15; and that 3:2 ratio was maintained into modern times. But in Bruges for the entire period of these tables (1351-1500), the journeymen or daily labourers always earned only half of the wages paid to their master craftsmen. These Anglo-Flemish comparisons should be taken into account in evaluating the significance of wage trends in the two countries.

Briefly, we may observe that the Flemish building craftsmen suffered a similar post-Plague decline in their real wages: with a fall in the RWI from 77.572 in 1351-55 (14.188 baskets) to 63.120 (11.545 baskets) in 1371-75 - a drop of 18.63 percent. While they then experienced a slow recovery, their initial realwage level (1351-55) was not finally surpassed until 1391-95. The subsequent rise - and decline - in their real wages into the fifteenth century will be compared with those for their English counterparts later in this study, which will provide a more complete understanding of the fluctuations in real wages.

\section{An alternate view of real wages: marginal productivity and the Marginal Revenue Product of labour.}

But before we can do so, we must first consider an alternative method of reckoning real wages, for a proper evaluation of the Postan thesis. For most economists, the only proper way to reckon and explain changes in real wages is by calculating changes in the marginal productivity labour - as explained earlier

${ }^{49}$ Some scattered Flemish rural data, for building craftsmen, are presented in Munro, 'Wage Stickiness', Table 15, pp. 262-63; and this study also presents evidence on building wages for other urban building craftsmen, in Mechelen and Antwerp (Tables 13-14, pp. 257-61), and for textile fullers in Ghent and Kortrijk, and Bruges policemen (Tables 11-12, pp. 264-65). For other wage data in England and the Low Countries (to 1500), including some for London, see also Munro, 'Builders' Wages', pp. 1013-76. 
in this study. As was also stressed earlier, the Ricardo-based Postan model stipulates that the marginal productivity of labour necessarily rose with population decline and the consequent shift in the land:labour ratio (to favour labour).

What then is the evidence for changes in agricultural labour productivity after the Black Death, and into the fifteenth century? Labour productivity did indeed rise in pastoral farming on many manors: for proportionally fewer men were required to manage larger flocks on an increased acreage. ${ }^{50}$ On arable lands, however, labour productivity generally fell over the seven decades from 1341 to 1421, as indicated by manorial records in the Winchester, Glastonbury, Ramsey, and other manorial estates. ${ }^{51}$

Bruce Campbell has provided the best resolution of this seeming paradox, and a demographic one. He had first demonstrated that, during the later thirteenth and early fourteenth century, growing population pressures provided the necessary incentives for needed agricultural innovations, especially in the form of very labour-intensive multiple crop rotations and related techniques to reduce the fallow, which thus became impractical with labour scarcities after the Black Death. He concludes that: 'it was consequently when labour was cheapest and most abundant that the most intensive arable farming systems attained their peak of productivity'; and his recent publications have amply demonstrated a significant decline in arable productivity (for land, labour, and capital) for much of England in the century after the Black Death. ${ }^{52}$

${ }^{50}$ On various Winchester manors, the number of sheep under the care of a single shepherd rose from 231 in 1341 to 342 in 1421, a 48.1 percent increase. See Farmer, ' Famuli', pp. 207-366, esp. Table 11.4, pp. 214-20); Christopher Dyer, Lords and Peasants in a Changing Society: the Estates of the Bishopric of Worcester, 680 - 1540, Past and Present Publications (Cambridge and New York: Cambridge University Press, 1980), pp. 150-51: noting that on the Worcester manors in the late 1380s, one shepherd managed a flock of 250-300 sheep, but that by 1450 one shepherd was managing a flock of 400-500 sheep. See also David Stone, 'The Productivity and Management of Sheep in Late Medieval England', Agricultural History Review, 51:i (2003), 1-22; David Stone, Decision-Making in Medieval Agriculture (Oxford and New York: Oxford University Press, 2005), and sources cited in the next note.

${ }^{51}$ According to Farmer, 'The Famuli’, pp. 207-366, esp. Table 11.4, pp. 214-20, labour productivity on arable lands of these Winchester manors fell from 34.3 acres per famuli ploughman in 1305 to 32.3 acres in 1382, thus only a marginal decline; but thereafter it fell much more precipitously, to 27.9 acres per ploughman in 1421, a 15.8 percent decline. For some corroborative evidence on the Glastonbury and Ramsey manors, see also Raftis, 'Peasants and the Collapse', pp. 191-206; David Stone, 'The Productivity of Hired and Customary Labour: Evidence from Wisbech Barton in the Fourteenth Century', The Economic History Review, 50:4 (November 1997), 640-56; David Stone, 'Medieval Farm Management and Technological Mentalities: Hinderclay Before the Black Death', The Economic History Review, 54:4 (November 2001), 61238. See also further if unexplained evidence in: Gregory Clark, 'Labour Productivity in English Agriculture, 1300 - 1860', in Land, Labour, and Livestock: Historical Studies in European Agricultural Productivity, ed. Bruce M.S. Campbell and Mark Overton (Manchester: Manchester University Press, 1991), Table 8.7, p. 225; Table 8.10, p. 235.

52 Bruce Campbell, 'Land, Labour, Livestock, and Productivity Trends in English Seignioral Agriculture, 1208-1450', in Land, Labour and Livestock, ed. Campbell and Overton, pp. 144-82 (quotation on p. 182). See also Bruce Campbell and Mark Overton, 'A New Perspective on Medieval and Early 
In any event, the Ricardo-based Postan model can be relevant only for agricultural labour. Certainly this model fails to demonstrate why late-medieval population decline should have led to any rise in industrial productivity. In woollen-textile manufacturing, for example, productivity in fact remained quite unchanged from the early fourteenth to the late eighteenth centuries. ${ }^{53}$ Some medieval industries did benefit, to be sure, from applications of more complex forms of water-powered machinery; but, in the leading industries -textiles, mining, and metallurgy -- most were instituted either long before or a full century after the Black Death. ${ }^{54}$ For late-medieval industries in general, evidence is lacking to indicate that the direct aftermath of the Black Death led to any other positive changes in labour productivity.

The proper and certainly more accurate method of reckoning real wages also involves the market values of the output of labour; and the correct formula is therefore: $\mathrm{RW}=\mathrm{MRP}_{\mathrm{L}}$ (the marginal revenue product of labour). That in turn equals the market value of that extra unit of output produced by that extra unit of labour applied to the production processes, as added to a fixed stock of land, capital, and technology. The Postan-Ricardo model does not explicitly recognize the inherent problem for agricultural labour, since it necessarily insists that relative grain prices fell with depopulation. Hence any rise in the marginal productivity of agricultural labour may well have been offset by a fall in its revenue product, i.e., with the fall in real grain and related food prices, as did happen, from the later 1370s. For industrial labour, however, a fall in food prices would certainly have contributed to their rise in real wages; or specifically for the wages

Modern Agriculture: Six Centuries of Norfolk Farming, c.1250 - c.1850’ , Past \& Present, no. 141 (November 1993), pp. 38 - 105; Bruce Campbell, 'Matching Supply to Demand: Crop Production and Disposal by English Demesnes in the Century of the Black Death', Journal of Economic History, 57:4 (December 1997), 827-58, Tables 4-5, pp. 837, 840; Campbell, English Seigniorial Agriculture, pp. 306-85, 411-40; Campbell, 'Agricultural Progress’, pp. 26-47; Campbell, 'Arable Productivity’, pp. 379-404.

${ }^{53}$ Fulling had been mechanized in England (water-wheels) from the thirteenth century, and remained the only manufacturing process in textiles to be mechanized before the modern Industrial Revolution. For evidence that textile productivity remained unchanged from the fourteenth to eighteenth centuries, see John Munro, 'Medieval Woollens: Textiles, Textile Technology, and Industrial Organisation, c. 800 - 1500', in The Cambridge History of Western Textiles, ed. David Jenkins, 2 vols. (Cambridge and New York: Cambridge University Press, 2003), Vol. I, pp. 181-227; Walter Endrei, 'La productivité et la technique dans l'industrie textile du XIIIe au XVIIe siècle,' in Produttività e tecnologia nei secoli XII-XVII: Atti delle "Settimana di Studi" e altri convegni, no. 3, Istituto Internazionale di Storia Economica "F. Datini”, ed. Sara Mariotti (Florence: Le Monnier, 1981), pp. 253-62.

${ }^{54}$ See Terry Reynolds, Stronger Than a Hundred Men: A History of the Vertical Water Wheel, The Johns Hopkins Studies in the History of Technology, new series 7 (Baltimore: The Johns Hopkins University Press, 1983); John Langdon, Mills in the Medieval Economy: England, 1300 - 1540 (Oxford and New York: Oxford University Press, 2004); John Munro, 'Industrial Energy from Water-Mills in the European Economy, $5^{\text {th }}$ to $18^{\text {th }}$ Centuries: the Limitations of Power', in Economia ed energia, secoli XIII - XVIII, ed. Simonetta Cavaciocchi, Atti delle 'Settimane di Studi' e altrie Convegni, Istituto Internazionale di Storia Economica, 'Francesco Datini', vol. 34 (Florence: Le Monnier, 2003), pp. 223-69. 
of any urban industrial labourers who produced no foodstuffs, but purchased them from the urban market. If, therefore, as economic theory contends, rises in real wages in the agrarian sector were necessarily translated to other sectors, as was argued earlier (see p. 8) the employment of urban industrial labour should have been restricted to those crafts in which, after adjustments, RW = MRP. Thus, any rise in relative industrial prices should have increased the employer's marginal revenue product and thus led to a rise in real wages, independently of any fall in the cost of living. Obviously, therefore, this standard definition of real wages, based on the marginal revenue product of labour, necessarily also involves the crucial role of commodity prices, as does in our earlier definition or real wages (with index numbers): RWI = NWI/CPI.

\section{The monetary approach to late-medieval economic history: the quantity theories of money}

Our final task in evaluating Postan’s Ricardo-based model is to compare the role of demographic and monetary factors in those price changes. That does not mean that any such evaluations involve so-called 'monetarist' ideology; for most modern economists agree that long-term trends in prices, those described as inflationary and deflationary, were and are today fundamentally though not exclusively monetary in origin. The necessary role of 'real factors' (including demographic) can be clearly seen in the modernized version of the Equation of Exchange (the so-called Fisher Identity): M.V = P.y. In this equation, 'M' stands for the national stock of high-powered money; ' $\mathrm{V}$ ', for the income velocity of that money; ' $\mathrm{P}$ ', for the consumer price index (CPI), and ' $y$ ' for real net national product (NNP - less depreciation), which necessarily equals real net national income, or current-valued NNI (P.y) deflated by the CPI. Note in particular that historically an increase in M has almost always led to some decrease in V, since V reflects society's desire to economize on scarce stocks of money. ${ }^{55}$

Most economists, however, prefer a variant known as the Cambridge Cash Balances approach, in which $\mathrm{V}$ is replaced by the much more predictable variable ' $\mathrm{k}$ ': that proportion of national income that society chooses to hold in active cash balances - those that do not earn investment income. Thus ' $\mathrm{k}$ ' is thus a measure of society's 'liquidity preference', determined by the collective demand for money for three reasons: to transact goods and service (current expenditures); to take advantage of speculative opportunities (potentially profitable but risky investments); and to provide financial security for any future adversities

55 The Price Revolution era provides the only historical exception when both $\mathrm{M}$ and $\mathrm{V}$ expanded at the same time. See Nicholas J. Mayhew, 'Population, Money Supply, and the Velocity of Circulation in England, 1300 - 1700’, Economic History Review, 2nd ser., 48:2 (May 1995), 238-57; John Munro, 'Money, Prices, Wages, and "Profit Inflation" in Spain, the Southern Netherlands, and England during the Price Revolution era, ca. 1520 - ca. 1650’, História e Economia: Revista Interdisciplinar, 4:1 (2008), 13-71. 
(insurance, risk aversion). Mathematically, ' $k$ ' is the reciprocal of $V(k=1 / V ; V=1 / k)$.

The Cambridge Cash Balances equation is: $\mathrm{M}=$ k.P.y. We should note in particular the changing relationships between the variables $\mathrm{M}, \mathrm{k}$, and $\mathrm{y}$ : for an increase in $\mathrm{M}$ will likely result in a lower rate of interest (if liquidity preference remains unchanged); and a lower rate of interest will in turn, along with expansion in monetized aggregate demand, stimulate economic growth and thus an increase in ' $y$ '. A lower rate of interest will also increase the incentive to hold larger cash balances (with no investment earnings). Thus in both equations, an increase in M may lead to some inflation, whose degree will be tempered by an increase in ' $k$ ' (reflecting a decrease in V), and by some increase in ' $y$ '. At the same time, other independent 'real' forces (population growth, technological changes, expanded trade and colonization, etc.) may also have stimulated an increase in ' $\mathrm{y}$ ', which may in turn call forth an accommodating increase in $\mathrm{M}$ (itself produced by financing increased investments). Thus, no supposedly 'monetarist' interpretations can ignore concurrent changes in real factors; similarly, no 'real' explanation can ignore related monetary changes.

\section{The role of monetary factors in medieval price trends ('long waves'): before the Black Death}

While most economists today would concur with this analysis, many historians will not, especially those with prejudices against 'monetarism', and especially those still wedded to the Postan thesis. A recent and very prominent example of such views is David Hackett Fischer's widely praised The Great Wave, which seeks to explain all historical 'long waves' of inflation and deflation exclusively in demographic terms, while explicitly rejecting monetary explanations. ${ }^{56}$ One cannot, however, dispute Fischer's contention that the first European inflationary 'long wave' began in the 1180s, representing the apogee of the Medieval Commercial Revolution era. While this period, commonly called the ‘long thirteenth century’ (1180-1320), was certainly also an era of pronounced population growth, it was, in fact, preceded by a momentous silver-mining boom in England (Cumberland-Northumberland), from the 1130s to the 1170s. According to Ian Blanchard, its annual silver outputs were then 'ten times more than had been produced in the whole of Europe’ for any year in the past seven centuries. By the 1170s, an even greater silver mining boom had begun in the Harz Mountains region of Saxony, which poured out vast quantities of silver until the early fourteenth century. ${ }^{57}$

\footnotetext{
${ }^{56}$ David Hackett Fischer, The Great Wave: Price Revolutions and the Rhythm of History(Oxford and New York: Oxford University Press, 1996). See my critical review in EH.Net Review, 24 February 1999, online at: http://eh.net/book_reviews/great-wave-price-revolutions-and-rhythm-history.

${ }^{57}$ Ian Blanchard, 'Lothian and Beyond: The Economy of the "English Empire” of David I', in Progress and Problems in Medieval England: Essays in Honour of Edward Miller, ed. Richard Britnell and John Hatcher (Cambridge: Cambridge University Press, 1996), pp. 23-45; Ian Blanchard, Mining, Metallurgy and Minting in the Middle Ages, vol. II: Afro-European Supremacy, 1125 - 1225 (African Gold Production
} 
We must also consider the contemporary accompanying financial revolution, also evident from the 1180s, in Genoa and Lombardy. Certainly the institutional innovations in both domestic deposit-banking and international foreign-exchange banking increased not only the supply of credit but also the volume of monetary flows, contributing to the economic expansion of this first 'long wave'. ${ }^{58}$

In Fischer's view, this 'long wave' came to an end with the demographic catastrophe of the Black Death (1347-52). In my view, the end of that 'long wave' came about much earlier; and it was due to an entirely different set of 'real' forces, but combined with monetary factors. ${ }^{59}$ From the 1290s up to and continuing into the Hundred Years War era (1337-1453), in both the eastern and western Mediterranean basins, and in NW Europe, an ever spreading stain of widespread, chronic, and often devastating warfare, combined with related piracy and brigandage, seriously disrupted or dislocated traditional patterns of regional and international trade, and their related monetary flows, certainly reducing the aggregate level of both by the 1330s. ${ }^{60}$ Far more harmful than the actual military conflicts were the war-related fiscal, monetary, and

and the First European Silver Production Long Cycle) (Stuttgart: Franz Steiner Verlag, 2001), pp. 583-685 (English silver production), pp. 687-710 (European production), pp. 711-61 (silver flows, pp. 1125-1225).

${ }^{58}$ Such financial instruments may have had more impact on the income velocity of money (flows) than on the supply of money (stocks). See Raymond de Roover, 'The Organization of Trade,' in Cambridge Economic History of Europe, Vol. III: Economic Organization and Policies in the Middle Ages, ed. M.M. Postan and E.E. Rich (Cambridge: Cambridge University Press, 1963), pp. 42 - 118; Herman Van der Wee, 'European Banking in the Middle Ages and Early Modern Period (476-1789)', in A History of European Banking, ed. Herman Van der Wee and G. Kurgan-Van Hentenrijk $2^{\text {nd }}$ edn. (Antwerp: Mercator Fonds, 2000), pp. 71 - 266; nn. 60, 89 below.

${ }^{59}$ Fischer, The Great Wave, pp. 11-34: section entitled 'The First Wave, the Medieval Price Revolution, 1180-1350'; but in fairness to Fischer, he also discusses, pp. 35-45, 'The Crisis of the Fourteenth Century', beginning with the Great Famines', while also referring to wars from the 1290s.

${ }^{60}$ John Munro, 'Bullionism and the Bill of Exchange in England, 1272-1663: A Study in Monetary Management and Popular Prejudice,' in The Dawn of Modern Banking, ed. Center for Medieval and Renaissance Studies UCLA (New Haven and London: Yale University Press, 1979), pp. 169-239; John Munro, 'Industrial Transformations in the North-West European Textile Trades, c. 1290 - c. 1340: Economic Progress or Economic Crisis?' in Before the Black Death: Studies in the 'Crisis' of the Early Fourteenth Century, ed. Bruce M. S. Campbell (Manchester and New York: Manchester University Press, 1991), pp. 110 - 48; John Munro, 'The Origins of the English 'New Draperies': The Resurrection of an Old Flemish Industry, 1270 - 1570,' in The New Draperies in the Low Countries and England, 1300 - 1800, ed. Negley B. Harte, Pasold Studies in Textile History no. 10 (Oxford: Oxford University Press, 1997), pp. 35-127; John Munro, 'The 'Industrial Crisis' of the English Textile Towns, 1290 - 1330,' Thirteenth-Century England: VII, ed. Michael Prestwich, Richard Britnell, and Robin Frame (Woodbridge, UK: Boydell Academic Press, 1999), pp. 103-41; John Munro, 'The Low Countries' Export Trade in Textiles with the Mediterranean Basin, 1200-1600: A Cost-Benefit Analysis of Comparative Advantages in Overland and Maritime Trade Routes', The International Journal of Maritime History, 11:2 (Dec. 1999), 1 - 30; John Munro, 'The "New Institutional Economics" and the Changing Fortunes of Fairs in Medieval and Early Modern Europe: the Textile Trades, Warfare, and Transaction Costs', Vierteljahrschrift für Sozial- und Wirtschaftsgeschichte, 88:1 (2001), 1 - 47. See also Edward Miller, 'War, Taxation, and the English Economy in the Late Thirteenth and Early Fourteenth Centuries', in War and Economic Development: Essays in Memory of David Joslin , ed. J.M. Winter (Cambridge: Cambridge University Press, 1975), pp. 11- 
commercial policies (trade bans). Especially pernicious were the monetary policies of coinage debasements, to finance wars from seigniorage profits, which, also beginning in the $1290 \mathrm{~s}$, invited retaliatory measures from victimized neighbouring states, reducing trade and bullion flows. ${ }^{61}$

The monetary structure of the early fourteenth-century European economy has yet to be fully explored, but some other forces promoting monetary contraction may be cited for this era. First, the output of European silver mines had begun to decline by the 1320s or 1330s, partly because of inevitable diminishing returns in mining, possibly also because of war-related disruptions. ${ }^{62}$ Postan had countered this particular argument by contending that, after centuries of continuous silver mining, the current preciousmetal stocks must have been so large that any decline in mined outputs would not have seriously affected the aggregate money supply. ${ }^{63}$ But, in opposing this argument, Nicholas Mayhew argued that the stock of medieval coined silver, far from being immutable, was perishable to some considerable degree: from wear, tear, and normal loss in circulation, from shipwrecks, unrecovered hoards, conversion into jewellery and plate, etc. Thus, unless European mints continually replenished the current coinage, medieval Europe's

32, whose negative views are disputed in Bridbury, 'Before the Black Death', pp. 393-410.

${ }^{61}$ See Munro, 'Coinage Debasements', pp. 15-32; sources in n. 33-4, 55 above; and Albert Girard, 'La guerre des monnaies', Revue de synthèse 19 (1940-45), 83-101; F. Graus, 'La crise monétaire du XIVe siècles', Revue belge de philologie et d'histoire, 29 (1951), 445-54; A. Grunzweig, 'Les incidences internationales des mutations monétaires de Philippe le Bel', Le moyen âge, 59 (1953), 117-72; R. Cazelles, 'Quelques reflexions à propos des mutations monétaires de la monnaie royale française (1295-1360)', Le moyen âge, 72 (1966), 83-105, and 251-78; Frederic C. Lane, 'The First Infidelities of the Venetian Lire', in The Medieval City, ed. H. A. Miskimin, David Herlihy, and A.L. Udovitch (New Haven and London: Yale University Press, 1977), pp. 43 - 64; Peter Spufford, Money and Its Use in Medieval Europe (Cambridge, Cambridge University Press, 1988), pp. 289-318 ('The Scourge of Debasement'). See also below pp. 32-34.

62 See Ian Blanchard, Mining, Metallurgy and Minting in the Middle Ages, vol. III: Continuing Afro-European Supremacy, 1250 - 1450 (Stuttgart: Franz Steiner Verlag, 2005), p. 971, dating the onset of aggregate European decline from the 1330s; see also the graph on p. 925, and text pp. 927-70; Philippe Braunstein, 'Innovations in Mining and Metal Production in Europe in the Late Middle Ages', Journal of European Economic History, 12 (1983), 573-91; John U. Nef, 'Mining and Metallurgy in Medieval Civilization', in Cambridge Economic History of Europe, Vol. II: Trade and Industry in the Middle Ages, ed. M.M. Postan and Edward Miller, revised edn. (Cambridge: Cambridge University Press, 1987), pp. 696-734; D. Kovacevic, 'Les mines d'or et d'argent en Serbie et en Bosnie médiévales', Annales: E.S.C., 15 (1960), 248-58; Oszkar Paulinyi, 'The Crown Monopoly of the Refining Metallurgy of Precious Metals and the Technology of the Cameral Refineries in Hungary and Transylvania, 1325-1700, with Data and Output', and Sima Cirkovic, 'The Production of Gold, Silver, and Copper in the Central Parts of the Balkans from the 13th to the 16th Century', both in Precious Metals in the Age of Expansion, ed. Hermann Kellenbenz, (Stuttgart, 1981), pp. 27-39, pp. 41-69.

63 Michael Postan, 'Note' (in response to:) W.C. Robinson, 'Money, Population, and Economic Change in Late Medieval Europe’, Economic History Review, 2nd ser., 12:1 (1959), 63-76, 77-82; Postan, 'Trade of Medieval Europe', pp. 211-12. 
aggregate coined money supply would have necessarily contracted over time. ${ }^{64}$

Two other contemporary monetary factors were likely peculiar to England. First, some historians have also contended that the England's foreign military expenditures, under Edward II and III, in the 1320s and 1330s, had led to major outflows of bullion, though the fall in mint-outputs and the onset of deflation seems to precede any evidence for any such drastic bullion outflows. ${ }^{65}$ Second, since England was then minting only silver -- and no gold before 1344, the very dramatic rise in the bimetallic ratio, from about 12.0:1 in the 1290 s to $14.2: 1$ in the late 1320 s may have instigated a large outflow of silver coinage to acquire the higher valued gold. Such bullion movements may have been necessary to permit England's inauguration of an effective gold coinage in the period 1344-52, though with a then falling bimetallic ratio. ${ }^{66}$

Firm statistical evidence for monetary contraction during the early fourteenth century, in terms of both deflation and falling mint outputs, is, however, available for England. The severe deflation - a fall of 35 percent in the CPI from the quinquennia 1321-25 to 1341-45 - has already been discussed (see pp. 11, 17, above); and is clearly evident in both Tables 1-2 and Figure 1. As Table 13 also clearly demonstrates, England's silver mint outputs, having achieved its highest ever volume in 1306-10 (mean of £125,835.83), following Edward I's successful full-scale recoinage, still remained high until the eve of the Great Famine; but it then plunged dramatically, with by far the steepest decline in English monetary history, reaching an abysmal nadir of just $£ 381.19$ in $1326-30$, recovering to a mean of only $£ 7,090.87$ in $1346-50$ (just 5.6 percent

64 Nicholas Mayhew, 'Numismatic Evidence and Falling Prices in the Fourteenth Century', Economic History Review, 2nd ser., 27:1 (1974), 1-15; Mayhew, 'Money and Prices', pp. 121-32. See also C. C. Patterson, 'Silver Stocks and Losses in Ancient and Medieval Times', Economic History Review, $2^{\text {nd }}$ ser., 25: 2 (May 1972), 205-35; Munro, 'Bullion Flows’, pp. 97-126; and n. 61 above.

${ }^{65}$ Edward Ames, 'The Sterling Crisis of 1337-1339', Journal of Economic History, 25 (1965), 496552; Albert Feavearyear, The Pound Sterling: a History of English Money, $2^{\text {nd }}$ edn. by E.V. Morgan (Oxford: Clarendon Press, 1963), pp. 13-18; Mavis Mate, 'High Prices in Early Fourteenth-Century England: Causes and Consequences', Economic History Review, 2nd ser., 28:1 (Feb. 1975), 1-16; Mayhew, 'Numismatic Evidence', pp. 1-15; Mayhew, 'Money and Prices', pp. 121-32; Michael Prestwich, 'Currency and the Economy of Early Fourteenth-Century England', in Edwardian Monetary Affairs, 1279-1344, ed. Nicholas Mayhew, BAR International Series no. 36 (Oxford: British Archeological Reports, 1977), pp. 45-58.

${ }^{66}$ See Lane, 'Infidelities of the Venetian Lire’, pp. 52-59; Peter Spufford, Handbook of Medieval Exchange, Royal Historical Society Guides and Handbooks no. 13 (London, 1986), graph 3 and Table II, pp. lxi-lxiii; Spufford, Money and Its Use, pp. 267-88, 340-42 (adjusting his dates by those from Lane); Mavis Mate, 'The Role of Gold Coinage in the English Economy, 1338 - 1400', Numismatic Chronicle, $7^{\text {th }}$ ser., 18 (1978), 126-41. The fall in the bimetallic ratio may have been due to both declining silver outputs from Bohemian mines and increasing supplies of West African (Sudanese) and Hungarian gold. See especially, Blanchard, Mining, III, pp. 950-70. 
of the 1306-10 peak), at the outbreak of the Black Death. ${ }^{67}$

Mint-accounts provide, however, only a very general, tenuous guide to current money supplies, especially because so often, with either debasements or recoinages, they reflect a recycling of current stocks; and thus mint outputs reflect a combination of both stocks and flows. Low mint outputs may mean only that neighbouring mints were offering higher prices for bullion; certainly they do not necessarily mean any corresponding contraction in the money supplies. Recently, however, two historians have used a combination of mint accounts and coin hoards to show that money supply contracted by over one half during the early to mid-fourteenth century. ${ }^{68}$ Even more enlightening is Figure 1, which compares the aggregate values of English mint outputs with the index numbers for the Phelps Brown \& Hopkins Consumer Price Index (quinquennial means). One can clearly see the lagged relationships, with changes in the price level following, within a few years, changes in mint ouptputs. Especially striking is the severe deflation from the later 1320s to the 1340s. One can hardly deny the obvious: that 'money matters'.

What is especially striking and peculiar about this deflation, and further evidence of genuine deflation, was the marked decline in the nominal wages of most English agricultural workers and building craftsmen, both rural (manorial) and urban, from 1331- 35 to 1341-45, as shown in Tables 6 - 10. The best evidence is in Tables 9-10, because these urban wage data do not suffer from the aforesaid 'compositional errors' that afflict Tables 6-9. ${ }^{69}$ From 1337 to 1340, the mean money wage (nominal wage) of a master building craftsmen of various small towns in south-east England fell from 4d per to 3d per day: a decline of

${ }^{67}$ For Edward I's recoinage of 1299-1300 and its aftermath, see Feavearyear, Pound Sterling, pp. 12-13 ; Nicholas J. Mayhew, 'From Regional to Central Minting, 1158-1464', in A New History of the Royal Mint, ed. Christopher Challis (Cambridge: Cambridge University Press, 1992), pp. 137-40; and other sources in nn. 64-5 above.

${ }^{68}$ See Mayhew, 'Money and Prices', Table I, p. 125: indicating that the coined money supply contracted from about $£ 1,100,00$ sterling in $1311-24$ to just $£ 500,000$ in the 1340 s. For a more recent estimate, see Martin Allen, 'The Volume of the English Currency, 1158 - 1470', Economic History Review, $2^{\text {nd }}$ ser., 54:4 (Nov. 2001), 595-611: Table 1, p. 603, indicating a larger estimated coined silver stock of $£ 1,900,000$ - $£ 2,300,000$ in 1319, falling to about $£ 700,000$ - $£ 900,000$ in 135;. Table 2, p. 607, providing, for 1470 , an estimate of just $£ 350,000$ to $£ 450,000$ in silver, $£ 400,000$ to $£ 500,000$ in gold, and thus a total of no more than $£ 750,000$ to $£ 950,000$. See also Martin Allen, 'Silver Production and the Money Supply in England and Wales, 1086 - c. 1500', The Economic History Review, $2^{\text {nd }}$ ser., 64:1 (Feb. 2011), 114-31; and Martin Allen, Mints and Money in Medieval England (Cambridge and New York: Cambridge University Press, 2012), chapter 10: 'The Changing Size of the Currency'.

${ }^{69}$ See above, p. 15. As Table 6 indicates, nominal wages for thresher and winnowers, unlike those for reapers and binders, having modestly declined in the 1320s, did not decline in the 1330s, though such data are again afflicted by these compositional errors. Similarly, the nominal wags for thatchers, having earlier fallen in the 1320s, then recovered, and did not fall until the early 1340s; those for slaters fell in the 1320s, but not later. See Table 8. 
25 percent. ${ }^{70}$ That very low wage-rate was maintained until 1352, several years after the Black Death (Tables 9-10). ${ }^{71}$ Despite this fall in nominal wages, the mason's real wages actually rose, if only briefly, in the late 1330s (peaking at RWI = 66.986 in 1336-40), because consumer prices had fallen even further.

\section{The role of monetary factors in the post-Plague inflations}

With the Black Death, and indeed with the increased tempo of the Hundred Years’ War (1337-1453), the monetary structures of western Europe soon became radically transformed. First, and foremost, as David Herlihy so aptly commented, 'men were dying, but coins were not'. ${ }^{72}$ Thus, whatever the current status of western European precious-metal mining, the effect of such drastic depopulations, perhaps as much as 40-50 percent of the total inhabitants, was undoubtedly to augment dramatically the per capita supplies of coined money. Second, the fiscal consequences of warfare in western Europe, of increased taxes and other levies, probably induced considerable dishoarding; while, at the same time the French, Flemish, Germans and Italian governments sought to finance and facilitate the necessary cash flows for warfare by engaging in horrendous coinage debasements. Third, as some historians have suggested, citing evidence from contemporary Italian literature, paintings, adornments in dress and housing, the socio-psychological consequences of the horrors from both plague and warfare was to foster fatalistic yet hedonistic spending sprees, all the more facilitated by suddenly inherited cash balances: i.e., to increase the income velocity of money. ${ }^{73}$

The overall consequences, as demonstrated in Tables 13 - 14, and Figures 1-2, for England and Flanders, was a truly momentous increase in coinage outputs, and consequently, from both increased stocks

${ }^{70}$ Wages for carpenters and masons in the college accounts of Oxford and Cambridge are more stable in this period, but with evidence of decline (from 4d to 3d) in the early 1340s. See Thorold Rogers, History of Agriculture and Prices, I, Table iii, p. 317; but again this table has compositional errors; see also the following note.

${ }^{71}$ As Tables 6-8 indicate, however, wages for manorial workers, both agricultural and industrial, did experience fluctuations not seen in the urban industrial wages; and those fluctuations included brief, periodic declines. Those fluctuations may reflect compositional errors rather than any decline in money payments.

${ }^{72}$ David Herlihy, Medieval and Renaissance Pistoia: The Social History of an Italian Town, 1200 -1430 (New Haven: Yale University Press, 1967), p. 125. If the aggregate supply of European coins did diminish, it did not do so to the extent of the immediate post-Plague population decline.

${ }^{73}$ The most frequently cited is Boccaccio’s famous Da Cameron. See Anthony Cassell, 'Boccaccio, Giovanni', in Dictionary of the Middle Ages, Vol. 2, ed. Joseph Strayer, et al (New York: Macmillan, 1983), pp. 277-90. See also Robert Lopez, 'Hard Times and Investment in Culture', in The Renaissance: Six Essays, ed. Wallace Ferguson, Metropolitan Museum of New York (New York: Harper and Row, 1962), pp. 29-52; Harry A. Miskimin, The Economy of Early Renaissance Europe, 1300 - 1460 (Cambridge: Cambridge University Press, 1975), pp. 132-40; Susan M. Stuard, 'Gravitas and Consumption', in Conflicted Identities and Multiple Masculinities: Men in the Medieval West, ed. Jacqueline Murray, Garland Medieval Casebooks vol. 25 (New York: Garland, 1999), pp. 215-42; Susan M. Stuard, Gilding the Market: Luxury and Fashion in Fourteenth-Century Italy (Philadelphia: University of Pennsylvania Press, 2006). 
and increased flows, drastic inflations. In England, that inflation, unaffected by any coinage debasements after 1351, persisted until the late 1370s; but in Flanders continued coinage debasements - nineteen from 1351 to 1388 (as noted earlier) -- aggravated the ongoing inflation, which came to an end only with the monetary reforms of 1389-90. ${ }^{74}$ Again, Figures 1 and 2 together demonstrate a clear if lagged relationship between increases in mint outputs and the ensuing inflations, in both countries.

The role of monetary factors in the later medieval deflations of ca. 1375-1415 and ca. 1440-1480: their impact on real wages

Thereafter, during the final quarter of the fourteenth-century, northwestern Europe experienced an equally dramatic deflation that continued into the fifteenth century, until the resumption of the Hundred Years' War. Once again Figures 1 and 2 demonstrate that lagged relationship between falling mint outputs and the ensuing and indeed dramatic fall in consumer prices, during the later fourteenth and early fifteenth centuries. Since most consumer prices fell rapidly, while money wages largely remained stable, their purchasing power finally did rise substantially - thirty years or more after the Black Death - as can be clearly seen in the real-wage indices in Tables 6-12, for England and Flanders.

In England, the quinquennial mean real wages of master building craftsmen in the small towns of SE England (Table 9) rose by 52.93 percent: from the previous trough in 1361-65 (near the end of the inflationary cycle) to the new peak of 1411-15: thus from an RWI of 60.397 (=6.746 baskets) to one of 92.369 (=10.318 baskets). For manorial carpenters, according to Farmer’s less reliable ‘national’ wage data, mean real wages rose by 40.45 percent, from trough to peak: from RWI of 55.102 in 1361-65 to their peak of 77.377 in 1406-10; for manorial masons, by somewhat more, by 45.79 percent (Table 7), over the same period; for manorial thatchers, by much more, 60.27 percent; and for tilers, by 51.55 percent, over the period 1361-65 to 1406-10 (Table 8). Experiencing many more fluctuations were the real-wage gains of manorial

74 The Flemish monetary reform of Dec. 1389 increased the silver content of the groot from 0.781 g. to 1.018g., an increase of 30.38 percent. For coinage debasements (from 1351) and inflations in England, Flanders and Brabant, see the publications of Munro cited in nn. 27 and 30 above; and also John Munro, 'Mint Outputs, Money, and Prices in Late-Medieval England and the Low Countries,' in Münzprägung, Geldumlauf und Wechselkurse/ Minting, Monetary Circulation and Exchange Rates, ed. Eddy Van Cauwenberghe and Franz Irsigler, Trierer Historische Forschungen, 7: Akten des 8th International Economic History Congress, Section C-7, Budapest 1982 (Trier, 1984), pp. 31-122; John Munro, 'Monnayage, monnaies de compte, et mutations monétaires au Brabant à la fin du moyen âge', in Études d'histoire monétaire, XIIe - XIXe siècles, ed. John Day, Études de l'Université de Paris VII et du Centre National des Lettres (Lille: Presses Universitaires de Lille, 1984), pp. 263-94; John Munro, 'Gold, Guilds, and Government: The Impact of Monetary and Labour Policies on the Flemish Cloth Industry, 1390-1435', Jaarboek voor middeleeuwse geschiedenis, 5 (2002), 153 - 205; John Munro, Wool, Cloth, and Gold: The Struggle for Bullion in Anglo-Burgundian Trade, ca. 1340-1478 (Brussels and Toronto: Editions de l’Université de Bruxelles and University of Toronto Press, 1973), pp. 43-63. 
reapers (Table 6), whose RWI rose overall 66.85 percent: from their low of 55.741 in 1356-60 to (ultimately) 93.009 in 1411-15. Over very these same years, the threshers and winnowers experienced an increase of only 49.06 percent; but by 1421-25 their RWI had risen to 77.243 (an overall gain of 65.39 percent).

In Flanders (Tables 11-12), real wages for building craftsmen in Bruges had also risen, from the end of inflation in 1386-90 to 1411-15, though by a far lesser extent: by 23.28 percent, from an RWI of 77.375 (14.152 baskets, for masters) to one of 95.384 (17.446 baskets). Just the same, their real wages still remained substantially higher than those for their English counterparts (Tables 9-10): 69.08 percent higher, for masters, but just 26.81 percent higher, for journeymen, in 1411-15 (see p. 18 above).

Those positive real-wage trends, in both England and Flanders, were quickly reversed, after the Battle of Agincourt in 1415 and the ensuing final phases of the Hundred Years' War, when much of northwestern Europe was again ravaged by an inflation that lasted until about 1440. The Low Countries and France in this era suffered from particularly severe coinage debasements during this war-torn period, unlike England, which experienced only one debasement, a purely defensive one, in 1411-12. ${ }^{75}$ The extent of the consequent inflation in Flanders and England can be seen again in Tables 1-5, and Figures 1-2. In Flanders, the mean CPI rose by 47.06 percent, from the trough of 1411-15 (95.309) to the peak of 1436-40 (140.166). Tables 11-12 reveal the adverse impact of that war-induced inflation on Flemish real wages: a sharp fall of 25.20 per cent, from an RWI of 95.384 in 1411-15 to one of 71.344 (13.049 baskets) in 1436-40; and that deterioration was aggravated by increases in urban excise taxes to help finance the wars. ${ }^{76}$

Even England, though spared by wars on home soil, experienced some inflation, if to a lesser extent (Tables 1-2): a 14.74 percent rise in the CPI, from 108.261 in 1411-15 to 124.218 in 1436-40. Consequently, urban industrial building craftsmen in SE England, with static nominal daily wages (at 6d), experienced a 12.85 percent decline in real wages (Tables 9-10) during this same period: with a fall in the mean RWI from 92.369 (10.318 baskets) to one of 80.504 (8.992 baskets) over this same period. The English rural scene was, however, more complex, with fluctuating wage rates, possibly reflecting the aforesaid compositional errors,

${ }^{75}$ See Munro, Wool, Cloth, and Gold, pp. 60-103; Tables C- G, pp. 198-204; Munro, 'Coinage Debasements', pp. 24-32. The English debasement of 1411, the first in sixty years (since 1351), reduced the silver content by 16.667 percent.

76 See n. 103 below. Fischer's depiction of this era, in The Great Wave, pp. 45-63, as 'The Equilibrium of the Renaissance, 1400-1470' is hardly apt. 
as shown in Tables 6-8. ${ }^{77}$ Thus, while manorial reapers and binders also experienced a decline in real wages in this same period, by 16.57 percent, manorial threshers experienced a gain of 11.09 percent. Among manorial building craftsmen, the thatchers experienced a gain of 16.62 percent; the carpenters, a smaller gain of 8.79 percent, while real wages for masons and slaters were virtually unchanged.

With the end of the Hundred Years War in 1453 - though followed by the domestic Wars of the Roses in England (1455-1487), that war-induced inflationary era was succeeded by yet another era of deflation, this time the most prolonged of the late-medieval era, actually commencing in the 1440s, and as severe as that of the later fourteenth century (Tables 1-5). In England, from peak to trough, from 1436-40 to $1476-80$, the CPI fell by 25.40 percent, from 124.218 to 92.667 ; in Flanders, similarly from peak to trough, from 1436-40 to 1461-65 (followed by more debasements), the corresponding CPI fell even more, by 36.71 percent, from 140.166 to 88.705 .

This era in turn also produced the most substantial real-wage gains in the later medieval era, for both England and Flanders; but for both regions, such gains must be seen in the perspective of the previous era of falling real wages, at least for urban industrial artisans, from ca. 1415 to ca. 1440 . From 1436-40 to the peak of real wages in 1476-80, the mean real wages for urban building craftsmen in the towns of SE England rose 34.05 percent: from a RWI of 80.504 (8.992 baskets, for masters) to one of 107.913 (12.054 baskets). ${ }^{78}$ Similar increases in real wages can also be found for manorial wage earners, though the validity of the data in Tables 6-8 are further undermined by the paucity of manorial accounts from this era. For the same period, from 1436-40 to the peak of 1476-80, the RWI for carpenters rose by 44.50 percent; that for masons, by 43.12 percent (Table 7); for slaters/tilers, by 47.14 per cent; and for thatchers, by 34.37 percent (Table 8). For agricultural workers (Table 6) the data are even more sparse and terminate earlier. The RWI for manorial threshers rose by 41.79 percent over the shorter period, from 1436-40 to 1471-75; and that for reapers, for the even shorter period from 1436-40 to 1461-65, rose by 46.96 percent. Finally, in Flanders (Tables 11-12),

${ }^{77}$ For other problems in utilizing English manorial wage rates in the fifteenth century, contending that they were not indicative of real incomes in rural societies, especially wage rates for season workers, see John Hatcher, 'Unreal Wages: Long-Run Living Standards and the 'Golden Age' of the Fifteenth Century', in Commercial Activity, Markets and Entrepreneurs in the Middle Ages: Essays in Honour of Richard Britnell, ed. Ben Dodds and Christian D. Liddy (Woodbridge: The Boydell Press, 2011), pp. 1-24.

${ }^{78}$ In London, in the building accounts for Westminster Abbey and the London guild houses, the nominal daily wage rate for master craftsmen (carpenters, mason, tilers) had risen from 7.0 - 7.5 to a standard $8.0 \mathrm{~d}$ by the $1420 \mathrm{~s}$, remaining at the level for the rest of the century: one third higher than the standard $6 \mathrm{~d}$ rate in the smaller towns of SE England. But without a London-based cost of living index, we cannot properly estimate their real wages. For London wages, see Munro, 'Wage Stickiness', pp. 196-98, 202, 211, and 232 (Table 2). 
the Bruges building craftsmen enjoyed a similar increase in their real wages of 45.98 per cent, from the same trough of 1436-40 to their real-wage peak of 1471-75: from a mean RWI of 71.344 (13.049 baskets, for masters) to one of 104.148 (19.049 baskets).

In Flanders, this pronounced deflationary trend, with the corresponding rise in real wages, was briefly halted and then reversed in the later 1470s and 1480s, especially with the anti-Habsburg civil wars in Flanders (to 1492), when the southern Low Countries experienced the most horrendous coinage debasements of the fifteenth century. From December 1477 to July 1489, the Flemish groot lost one-half of its fine silver content. Some of the price increases were also due to wartime 'supply shocks' and other disruptions. ${ }^{79}$ Thus, over this period, the Flemish CPI soared by 92.16 percent (almost doubling): from a mean of 96.017 in 147175 to 184.511 in 1486-90 (Tables 3-4). But, after several mint adjustments between January 1490 and September 1493, to restore much of the lost silver contents, price stability and then deflation ensued, so that the Flemish CPI fell by 45.66 percent to reach a mean of 100.255 in $1496-1500{ }^{80}$ In both Flanders and England (for which the CPI in 1496-1500 was 98.538) that deflationary trend continued until the onset of the Price Revolution in 1516-20 (a persistent inflation lasting until ca. 1650). ${ }^{81}$

\section{Forces for monetary contraction: the debate about late-medieval 'bullion famines'}

While the periodic late-medieval eras of inflation can be readily explained by a combination of warinduced fiscal and monetary policies, especially by coinage debasements, and by wartime 'supply shocks', more difficult to explain are the post-Plague deflations, though less so than the pre-Plague deflation (see pp. 25-26 above). Currently the favoured explanations concern the two so-called 'bullion famines': from the 1370 s to the 1410 s; and from the 1440 s to the 1470 s. But the published analyses are often contradictory.

The predominant theories focus upon a net reduction in the supply of precious metals, from three possible causes. The first suggested cause, one examined earlier for the pre-Plague 'bullion famine', was

${ }^{79}$ See Peter Spufford, 'The Debasement of the Coinage and its Effects on Exchange Rates and the Economy: in England in the 1540s, and in the Burgundian-Habsburg Netherlands in the 1480s', in Money in the Pre-Industrial World: Bullion, Debasements, and Coin Substitutes, ed. John Munro (London: Pickering \& Chatto, 2012), pp. 68-85.

${ }^{80}$ The fine silver content of the groot was reduced from $0.5222 \mathrm{~g}$. in Dec. 1477 to $0.2636 \mathrm{~g}$ in Dec. 1489; but by Sept. 1493, it had been restored to $0.4994 \mathrm{~g}$ (95.63 percent of the 1477 level). See: http://www.economics.utoronto.ca/munro5/ResearchData.html: 'Statistical Tables on Medieval and Early Modern Money and Coinage’:

${ }^{81}$ John Munro, ‘The Monetary Origins of the "Price Revolution:” South German Silver Mining, Merchant-Banking, and Venetian Commerce, 1470-1540', in Global Connections and Monetary History, 1470 - 1800, ed. Dennis Flynn, Arturo Giráldez, and Richard von Glahn (Aldershot and Brookfield, Vt: Ashgate Publishing, 2003), pp. 1-34; Munro, 'Profit Inflation', pp. 13-70. 
simply a continuation and severe worsening of Europe's late-medieval mining slump, with a veritable cessation of silver mining in some regions, so that even the subsequent post-Plague opening of new mines in Serbia and Sardinia failed to compensate for the sharp decline in outputs elsewhere. The much more important cause, for most historians, was western Europe’s supposedly worsening of balance-of-payments deficit with Asia, with consequent bullion outflows via the Levant and the eastern Baltic. ${ }^{82}$ A third, if lesser cause, aggravating that payments deficit, was a severe diminution in imports of 'Sudanese' West African gold, in Italian trade with the North Africa ports. That decline became even more severe from the 1370s, after the collapse of the once mighty Mali Empire and the inability of its successor, the Songhai Empire to guarantee security along the trans-Saharan trade routes to Mediterranean ports. ${ }^{83}$

The problem with this 'balance of payments' explanation, however, is that western Europe had chronically sustained a deficit in payments with the East, from ancient Roman times. Despite Ashtor's impressive evidence for Venice's large silver exports to the Levant in the later fifteenth century, there is little evidence to demonstrate that an overall European balance-of-payments deficit had been worsening from a full century earlier. ${ }^{84}$ Indeed, a major factor that helped to end the so-called 'bullion famine' era in the later

${ }^{82}$ For problems in mining see n. 62 above, especially Blanchard, Mining, III, pp. 974-77; John Nef, 'Silver Production in Central Europe, 1450-1618', Journal of Political Economy, 49 (1941), 575-91; Nef, 'Mining', pp. 696-734. For balance of payments deficits, see Harry Miskimin, 'Monetary Movements and Market Structures: Forces for Contraction in 14th and 15th Century England', Journal of Economic History, 24 (1964), 470-90; Harry Miskimin, 'Money and Money Movements in France and England at the End of the Middle Ages', in Precious Metals in the Later Medieval and Early Modern Worlds, ed. John F. Richards (Durham: Carolina Academic Press, 1983), pp. 79-96; Miskimin, Economy of Early Renaissance Europe, pp. 25-72, 132-57; R. S, Lopez, Harry Miskimin, and A.L. Udovitch, 'England to Egypt, 1350 - 1500: Long Term Trends and Long Distance Trade', in Studies in the Economic History of the Middle East: From the Rise of Islam to the Present Day, ed. M.. A. Cook (Oxford: Oxford University Press, 1970), pp. 93-128; John Day, 'The Great Bullion Famine of the Fifteenth Century', Past and Present, no. 79 (May 1978), 1-54; John Day, 'The Question of Monetary Contraction in Late Medieval Europe', Nordisk Numismatisk Arsskrift: Nordic Numismatic Journal, 1981: Coinage and Monetary Circulation in the Baltic Area, c. 1350 - c. 1500 (Copenhagen, 1981), pp. 12-29; reprinted in John Day, The Medieval Market Economy (Oxford: Basil Blackwell, 1987), pp. 55-71; Spufford, Money and Its Use, pp. 267-88, 340-42.

${ }^{83}$ See Day, 'Bullion Famine’, pp. 36-39; E. W. Bovill, The Golden Trade of the Moors, 2nd edn. (Oxford: Oxford University Press, 1968), pp. 13-44, 79-131; and Blanchard, Mining, vol. III, pp. 1111-1339, esp. pp. 1165-1210. For a contrary view, see Angus MacKay, Money, Prices and Politics in FifteenthCentury Castile (London: Royal Historical Society, 1981).

${ }^{84}$ Eliyahu Ashtor, Les métaux précieux et la balance des payements du Proche-Orient à la basse époque (Paris: S.E.V.P.E.N , 1971); Eliyahu Ashtor, A Social and Economic History of the Near East in the Middle Ages (London: Collins, 1976), pp. 319-31; Eliyahu Ashtor, The Levant Trade in the Later Middle Ages (Princeton: Princeton University Press, 1983). But see also John Munro, 'South German Silver, European Textiles, and Venetian Trade with the Levant and Ottoman Empire, c. 1370 to c. 1720: A NonMercantilist Approach to the Balance of Payments Problem', in Relazioni economiche tra Europa e mondo islamico, secoli XIII - XVIII/ Europe's Economic Relations with the Islamic World, $13^{\text {th }}-18^{\text {th }}$ Centuries, ed., Simonetta Cavaciocchi, Atti delle ‘Settimana di Studi’ e altri convegni, no. 38 (Florence: Le Monnier, 2007), pp. 907-62. 
fifteenth century was the Central European silver-copper mining-boom, which began during the very nadir of deflation in the 1460s, when the consequently high value of silver promoted the application of previous innovations in both civil and chemical and engineering, for mining and metallurgy. That mining boom augmented European silver production by over five-fold by the 1530s; and without such large increases in its silver stocks, Venice would never have been able to conduct such an increased volume and value of trade with the Levant in the 1490s. ${ }^{85}$ Furthermore, the success of mints in England, France, and the Low Countries in reviving coinage out puts, in the 1420s and 1430s, well before this mining boom commenced, indicates the absence of a clear, downward linear trend for any augmented bullion outflows to the 'East'. A greater problem with all of the theses concerning a steadily worsening diminution in Europe's physical stocks of precious metals is the failure to prove that, by the mid-fifteenth century, those stocks had declined more than had Europe's population, i.e., by about 50 percent. As noted earlier, the initial impact of the Black Death was to create a per capita surplus of precious metals (see p. 33 above).

An alternative explanation for late-medieval monetary contractions may be found in examining not stocks but flows: i.e., adverse changes in the income velocity of money, or in the demand for idle cash balances, which may be related to the pernicious effects of warfare and plagues, from the 1370s. Chronic, devastating warfare throughout so much of Europe, combined with more plagues and depopulation, produced even more severe dislocations to established trade patterns, while sharply raising transaction costs, thus reducing even more flows of both commodities and bullion. Worse, the aforementioned responses to political and military conflicts, in terms of commercial blockades, confiscations, and especially coinage debasements that were the most severe ever encountered in medieval Europe, curtailed bullion flows even more drastically, through policies known as ‘bullionism’. Most rulers, in defending themselves against aggressive debasements by their neighbours, necessarily banned the domestic circulation of most foreign coins, especially silver coins

85 The first set involved adits and mechanical pumps to permit much deeper, well drained mining shafts; and the second is known as the Saigerhütten process, for smelting argentiferous-cupric ores with lead to separate the two metals. See Ekkehard Westermann, 'Die Bedeutung des Thüringer Saigerhandels für den mitteleuropäischen Handel an der Wende vom 15. zum 16. Jahrhundert', Jahrbuch für die Geschichte Mittelund Ostdeutschlands, 21 (1972), 68-92; Ekkehard Westermann, 'Zur Silber- und Kupferproduktion Mitteleuropas vom 15. bis zum frühen 17. Jahrhundert: über Bedeutung und Rangfolge der Reviere von Schwaz, Mansfeld und Neusohl', Der Anschnitt: Zeitschrift für Kunst und Kultur im Bergbau, 38 (May-June 1986), 187 - 211; Nef, 'Silver Production', pp. 575-91; Nef, 'Mining', pp. 696-734; Braunstein, 'Innovations', pp. 573-9; Spufford, Money and Its Use, pp. 363-77; John Munro, 'The Central European Mining Boom, Mint Outputs, and Prices in the Low Countries and England, 1450 - 1550', in Money, Coins, and Commerce: Essays in the Monetary History of Asia and Europe (From Antiquity to Modern Times), ed. Eddy H.G. Van Cauwenberghe (Leuven: Leuven University Press, 1991), pp. 119 - 83; Munro, 'Monetary Origins', pp. 1- 34. See also Blanchard, Mining, III, 973-974: dating the European adoption of the Saigerhüttenprozess to the 1390s. 
(all the more subject to surreptitious debasements); and such bans also forced most merchants to surrender all foreign coin to as bullion to their local mints. More important, in seeking to attract more bullion to their own mints, to increase coinage outputs and their seigniorage revenues, virtually all rulers banned its export. Even when enforcement of those bans failed to prevent international exchanges of precious metals, they still depressed monetary and trade flows by raising commercial transaction costs. ${ }^{86}$

Finally, the noxious combination of warfare, famines, plagues, depopulation, and consequent commercial disruptions led to periodic but often severe economic depressions, aggravated by these selfserving monetary policies and higher taxes. Commencing by the late 1370s and 1380s, the worst of all these cyclical depressions took place in the mid fifteenth century. ${ }^{87}$ Such conditions also bred a more general climate of insecurity and widespread pessimism that further discouraged spending and investment and increased hoarding, which together further deepened those depressions. Thus by the 1370s that post-Plague social climate of hedonistic spending-sprees had given way to much more pervasively gloomy and pessimistic outlooks amongst the populace in general that increased their demand for idle cash-balances. ${ }^{88}$ That led to more and more hoarding, which is a self-justifying deflationary phenomena. For, as prices fell, the rational response was to save rather than to spend, in anticipation of even lower future prices, and thus of the increased value of hoarded coins. As Figures 1 and 2 clearly demonstrate, monetary contraction and deflation were together the predominant trend from the 1370 s to about 1510, though interrupted by the inflationary final phases of the Hundred Year's War and the Flemish civil wars of the 1480s. Those military conflicts produced drastic coinage debasements, vast increases in taxes and military expenditures, which in turn all

${ }^{86}$ See sources in nn. 33, 61 above; and also, Munro, Wool, Cloth, and Gold, pp. 11-41; and the various studies in Munro, Bullion Flows.

${ }^{87}$ See in particular John Hatcher, 'The Great Slump of the Mid-Fifteenth Century,' in Progress and Problems in Medieval England: Essays in Honour of Edward Miller, ed. Richard Britnell and John Hatcher (Cambridge: Cambridge University Press, 1996), pp. 237-72; Pamela Nightingale, 'England and the European Depression of the Mid-Fifteenth Century,' The Journal of European Economic History, 26:3 (Winter 1997), 631-56; John Munro, 'Economic Depression and the Arts in the Fifteenth-Century Low Countries’, Renaissance and Reformation, 19 (1983), 235-50.

${ }^{88}$ See Spufford, Money and Its Use, pp. 346-47, citing the views of many contemporary European observers who believed that 'thesaurisation [hoarding, the accumulation of plate] was the main cause of the bullion famines' during the later fourteenth and early fifteenth centuries. Disagreeing, he comments that: 'In retrospect it appears that it was itself in part a response to the famine. Nevertheless it made that shortage worse, although the export of precious metals from Europe now seems more important, combined with the failures of the mines to make good the losses'. For increased coin hoards in this era, see J. D. A. Thompson, Inventory of British Coin Hoards, A.D. 600 - 1500 (Oxford: Royal Numismatic Society Publications, 1956); for increased consumption of precious metals in dress and art, as a form of hoarding, see Stuard, 'Gravitas and Consumption', pp. 215-42; and Stuard, Gilding the Market; for evident reductions in the income velocity of money, see Mayhew, 'Population’, pp. 238-57. See also Munro, 'Bullion Flows', pp. 97-122. 
promoted temporary dishoarding. But when peace resumed, so did deflation.

\section{The role of credit and banking institutions: did they remedy late-medieval bullion scarcities?}

Nevertheless, according to many historians, a supposed growth in the use of credit during the later Middle Ages offset or counteracted those deflationary forces: particularly through the agency of deposit-andtransfer banking and bills-of-exchange banking. Yet neither was an innovation in this era, and both saw their most rapid initial diffusion during the later thirteenth and early fourteenth century. Why credit instruments largely failed to provide a sufficient remedy for period monetary contractions in late-medieval Europe is very complex, but may be briefly summarized here. First, late-medieval Europe experienced very few additional innovations; and most credit instruments were still far from being effective substitutes for coined money, with the possible though still dubious exception of a very few West-European towns whose commerce was dominated by Italian merchant-bankers. Second, much more widespread and more powerful forces, economic and political, involving increased hostility from both church and state, seriously impeded the employment or circulation of credit, with a multitude of examples to be cited in England, France, the Low Countries, and many Hanse towns, if not so much in Italy itself. Indeed, in both England and the Low Countries, latemedieval nationalist monetary policies effectively prevented the emergence of deposit-banking in the former, and virtually closed down such banks in the latter, following the Burgundian unification of the Low Countries, in a series of ever more severe ordinances $\left(1433-35,1467,1480\right.$, and 1489) ${ }^{89}$

Third, because of those increasingly hostile attitudes from state-dominated legal institutions, despite the growth of a more international Law-Merchant, the enforcement of debt repayments, especially those involving holograph documents, became even more costly and ineffective, thus restricting credit instruments to a small circle of merchants who knew and trusted each other. Fourth, therefore, most European states and principalities, even in Italy, failed to provide the legal institutions to ensure and protect true negotiability. ${ }^{90}$

${ }^{89}$ See in particular Raymond de Roover, Money, Banking and Credit in Mediaeval Bruges: Italian Merchant-Bankers, Lombards, and Money Changers: A Study in the Origins of Banking (Cambridge, Mass., 1948), pp. 130, 236-46, 331-57, esp. pp. 339-42; De Roover, 'Organization of Trade', pp. 42-118; Herman Van der Wee, Growth of the Antwerp Market and the European Economy, 14th - 16th Centuries, 3 vols. (The Hague, 1963), II, pp. 85-86, 333-40, 355-58; Herman Van der Wee, 'Monetary, Credit, and Banking Systems', in Cambridge Economic History of Europe, vol. V: The Economic Organization of Early Modern Europe, ed. E.E. Rich and C.H. Wilson (Cambridge: Cambridge University Press, 1977), pp. 302, 312, 32324, 361-62; Van der Wee, 'European Banking', pp. 87-112, 125-33.

${ }^{90}$ John Munro, 'The Medieval Origins of the Financial Revolution: Usury, Rentes, and Negotiablity', The International History Review, 25:3 (Sept. 2003), 505-62; John Munro, 'The International Law Merchant and the Evolution of Negotiable Credit in Late-Medieval England and the Low Countries', in Banchi pubblici, banchi privati e monti di pietà nell'Europa preindustriale: amministrazione, tecniche operative e ruoli economici, ed. Dino Puncuh, Atti della Società Ligure di Storia Patria, Nouva Serie, Vol. XXXI (Genoa: 
Such a conversion of credit instruments into cash or goods is the fundamentally necessary condition in allowing them to augment the effective money supply. Fifth, credit instruments were far from being divorced from the use of coined money. As Spufford, Nightingale, Spooner, Mueller, Mayhew and others have effectively demonstrated, credit either expanded or contracted with the coined money supply in the latemedieval and early-modern economies, usually in a non-proportional fashion. ${ }^{91}$ As Mayhew so aptly commented: 'credit reflected the supply of coin rather than compensated for it' ${ }^{92}$

\section{Conclusions on the Postan paradigm and the importance of money for late-medieval prices and wages}

The chief conclusions therefore are, first, that the Postan paradigm does not hold true in asserting that demographic factors were the predominant determinants of change in prices, including wages, during the medieval era. Furthermore, there is very little if any evidence to indicate that demographically-induced improvements in labour productivity (from changes in the land:labour ratio) had anything to do with the changes in real wages recorded in this study, except possibly in pastoral agriculture (for which wage data are largely missing). Nevertheless, the rise in both nominal and real wages for urban building craftsmen, in both England (Tables 9-10) and Flanders (11-12) in the early fifteenth century are not adequately explained by other models used in this study; and they may reflect productivity gains not yet explained: possibly changes in Total Factor Productivity rather than just by labour productivity. ${ }^{93}$

The second major conclusion is that monetary factors deserve far more consideration in influencing changes in both commodity prices and real wages than Postan and his followers were willing to admit. ${ }^{94}$ Demographic factors were not, however, irrelevant and indeed were linked to monetary factors. In the context of the modernized Equation of Exchange (M.V = P.y), population decline was often important in

Società Ligure di Storia Patria, 1991), pp. 49 - 80; Munro, 'Bullionism’, pp. 169-39.

${ }^{91}$ See Spooner, The International Economy, pp. 3, 53-71; Reinhold Mueller, “ "Chome l'ucciello di passegio": la demande saisonnière des espèces et le marché des changes à Venise au moyen âge', in Études d'histoire monétaire, XIIe-XIXe siècles, ed. John Day (Lille: Presses universitaires de Lille, 1984), pp. 195220; Pamela Nightingale, 'Monetary Contraction and Mercantile Credit in Later Medieval England', Economic History Review, 2nd ser. 43:4 (November 1990), 560 - 75; Spufford, Money and Its Use, pp. 34548. See also the next note.

${ }^{92}$ Mayhew, 'Money and Prices', p. 121: 'Lending does not contract in time of glut of coin or expand in times of scarcity'. See also Mayhew, 'Population', pp. 238-57.

${ }^{93}$ See Munro, 'Builders’ Wages’, pp. 1046-1047: from changes in land, labour, and capital.

${ }^{94}$ For example, see Hatcher, Plague, pp. 47-54, placing primary emphasis on demographic factors, while admitting that monetary forces may have had some influence on declining prices. For a more nuanced view, giving a greater role to monetary forces, see Hatcher, ‘The Great Slump', pp. 237-72. 
influencing changes in the income velocity of money and always crucial in determining independent changes in ' $y$ ' (i.e., the deflated NNI or NNP), if only by influencing changes in relative prices. Furthermore, a falling population obviously determined per capita money supplies.

\section{The problem of wage stickiness}

For the post-Black Death era, real wages were generally determined by what is called 'wage stickiness': i.e., the downward rigidity of nominal wages during periods of deflation. During times of inflation, nominal wages were usually not so 'sticky', but clearly, from all the historical evidence, they generally rose to a much lesser extent than did the Consumer Price Index. Consequently, in so far as monetary factors were chiefly responsible for long-term trends of deflation and inflation, they also played a strong role in determining real wages under such conditions of 'stickiness'. Thus, real wages necessarily rose during periods of falling consumer prices and necessarily fell during periods of rising consumer prices and did so in the ensuing early-modern era of the Price Revolution. ${ }^{95}$ That, as we have seen, is self evident from the first equation used in this study to examine the patterns of real wage changes: RWI = NWI/CPI.

But that is only half the story, for obviously monetary factors could not possibly have determined the nature of 'wage stickiness' itself. By standard economic theory, monetary contraction ought to have led to a fall in nominal wages, as the price for labour. Indeed, we saw that in England during the severe deflation from the late 1320s to the eve of the Black Death, money wages for industrial craftsmen (and some agricultural workers) did fall; but because they did not fall as much as did commodity prices, real wages rose, if only briefly. Thereafter, however, money wages for industrial craftsmen and labourers in England did not fall for seven centuries: not until the 1920s. ${ }^{96}$ Such 'wage-stickiness' is therefore largely a post-Plague phenomenon - as evident in Flanders (Tables 11-12) as in England (Tables 6-10); but John Langdon has recently found some instances of sticky wages before the Black Death. ${ }^{97}$ This very complex subject has been

95 John Munro, 'The Price Revolution', in The New Palgrave Dictionary of Economics, $2^{\text {nd }}$ edition, ed. Steven N. Durlauf and Lawrence E. Blume (London and New York: Palgrave Macmillan, 2008), vol. VI, pp. 631-34; Munro, 'Monetary Origins’, pp. 1-34; Munro, 'Profit Inflation’, pp. 13-71;

96 Phelps Brown and Hopkins, 'Building Wages’, pp. 195-206.

97 John Langdon, 'Waged Building Employment in Medieval England: Subsistence Safety Net or Demographic Trampoline?', in Survival and Discord in Medieval Society: Essays in Honour of Christopher Dyer, ed. Richard Goddard, John Langdon, and Miriam Müller, The Medieval Countryside no. 4 (Turnhout: Brepols Publishers, 2010), pp. 109-26; John Langdon, 'Minimum Wages and Unemployment Rates in Medieval England: The Case of Old Woodstock, Oxfordshire, 1256-1357', in Commercial Activity, Markets and Entrepreneurs in the Middle Ages: Essays in Honour of Richard Britnell, ed. Ben Dodds and Christian D. Liddy (Woodbridge: The Boydell Press, 2011), pp. 35-44. 
examined in a number of recent studies, so that a detailed analysis is not required in this current study. ${ }^{98}$ Suffice it to say that wage-stickiness became essentially socio-institutional in nature, especially when wageearners were better able to organize and resist arbitrary reductions in their daily pay. Few would now doubt the proposition that the bargaining power of labour increased substantially in the aftermath of the Black Death. ${ }^{99}$ Wage stickiness tended to be much more prevalent in industrial occupations: not just in the building trades (carpenters, masons, pavers, etc.), but also in textiles and services (e.g. for policemen in Flanders), in both villages and towns, in both England and the Low Countries. But in the latter, industrial wage-stickiness became less pronounced in rural villages during the mid-fifteenth century depression. ${ }^{100}$ Wage stickiness was also much less evident in purely agricultural occupations (with piece-work wages); but the apparent wage fluctuations in Tables 6-8 may again simply reflect the aforesaid 'compositional errors'.

\section{Real wages and real incomes}

Three more intractable problems concerning wages remain. First, our evidence concerns only daily wages - not annual incomes; and we cannot begin to measure such incomes without better knowledge of the average number of days worked each year. In other publications, I have provided various justifications for an estimate of 210 days per year for the building trades in the fifteenth century (an estimate lower than most). ${ }^{101}$ Second, we do not know to extent to which male wage earners practised more than one craft and/or gained supplementary incomes from other sources, in agriculture or commerce; nor do we know the contributions to total household incomes from wives and other family members.

Third, we must remember that wage-earners were still a minority in society, though an important one. According to Penn and Dyer, 'at least one-third of the population of late-medieval England gained all or a

${ }^{98}$ See Munro, 'Wage Stickiness’, pp. 185 - 297; Munro, 'Builders’ Wages’, pp. 1013-76; Munro, 'Before and After the Black Death', pp. 335-364; Munro, 'Decline of English Demesne Agriculture', pp. 299-348; and the previous note. These studies, which use only silver money wages, also examine the extent to which wages were paid partially in kind, noting that the proportion (in value) fell from about one-half before the Black Death to about one-third, by the late fourteenth century.

${ }^{99}$ See for example the bitter, sometimes violent resistance of Flemish guilds to arbitrary wage cuts that the count's officials deemed a necessary part of the 1390 deflationary monetary reform, in Munro, 'Gold, Guilds, and Government', pp. 153 - 205; and n. 71 above.

${ }^{100}$ See the evidence for the Low Countries in Munro, 'Wage Stickiness', pp. 226-27, Tables 10-15, pp. 252-63; Munro, 'Builders' Wages', Tables 3-7a/b, pp. 1054-66. For the mid-fifteenth-century ‘depression’, see n. 87 above.

101 See n. 47 above. 
part of their livelihood' from cash wages. ${ }^{102}$ If, however, a fall in the cost of foodstuffs (80 percent of the consumer basket: Table 5) was the major factor in the rise in their real wages was, from the late 1370s, then possibly their gains were offset by a fall in real incomes for a much greater proportion of society: i.e., those who produced agricultural products for the market and those who traded in such goods. That situation, however, was far more true of fifteenth-century England than of more urbanized, and industrialized Flanders (more dependent on imported foodstuffs). Furthermore, as John Hatcher has recently pointed out, the apogee of the so-called 'Golden Age of the Labourer', in the mid-fifteenth century was also an era of deep depression in England (and also in the southern Low Countries). ${ }^{103}$ For the latter, this period also marked the most severe stage in the decline of its textile industries, and also one in which their urban inhabitants were forced to pay far higher excise taxes to meet obligations on previous, wartime borrowing. ${ }^{104}$

The behaviour of late-medieval prices and wages is a very complex one, for which the Postan demographic model provides the least satisfactory explanation. Those who still think that late-medieval prosperity depended on demographic factors should ponder the wise words of the late Ralph Davis: 'The economy of modern Europe would never have come into existence on the basis of population decline' ${ }^{105}$

${ }^{102}$ Simon Penn and Christopher Dyer, 'Wages and Earnings in Late Medieval England: Evidence from the Enforcement of the Labour Laws’, Economic History Review, ${ }^{\text {nd }}$ ser., 43:3 (Aug. 1990), 356-76.

${ }^{103}$ See Hatcher, 'Unreal Wages', pp. 1-24, with other strong arguments to oppose the 'Golden Age' thesis. See also sources cited in n. 87 above.

${ }^{104}$ See John Munro, 'The Usury Doctrine and Urban Public Finances in Late-Medieval Flanders (1220 - 1550): Rentes (Annuities), Excise Taxes, and Income Transfers from the Poor to the Rich', in $L a$ fiscalità nell'economia Europea, secoli XIII - XVIII/ Fiscal Systems in the European Economy from the $13^{\text {th }}$ to the $18^{\text {th }}$ Centuries, ed. Simonetta Cavaciocchi, serie II: Atti delle 'Settimane de Studi' e altri Convegni no. 39 (Florence: Firenze University Press, 2008), pp. 973-1026. Such urban excise taxes on consumption were not used in England, at least not to finance national warfare, until the English Civil War era.

${ }^{105}$ Ralph Davis, The Rise of the Atlantic Economies (Ithaca: Cornell University Press, 1973), p. 16. 


\section{Appendix: Postan on Money and Prices}

\section{in chronological order of publication:}

(1) Michael Postan, 'The Economic Foundations of Medieval Society', Jahrbücher für Nationalökonomie 161 (1951), ${ }^{106}$ repr. in Michael Postan, Essays on Medieval Agriculture and General Problems of the Medieval Economy (Cambridge: Cambridge University Press, 1973), p. 9

Yet even silver cannot be easily made to account for the economic trend. If changes in the supply of silver were responsible for the rise in prices, we would expect the rise to be 'general'; i.e. to affect more or less the entire range of medieval commodities entering into local trade. But most recent writers have pointed out that the movements of agricultural and industrial prices did not synchronize; that in the twelfth and thirteenth centuries industrial prices did not rise as high and as fast as the prices of wheat and did not fall or stagnate in the later Middle Ages.

(2) Michael Postan, 'The Trade of Medieval Europe: the North', in Cambridge Economic History of Europe, Vol. II: Trade and Industry in the Middle Ages, Michael Postan and E.E. Rich (Cambridge: Cambridge University Press, 1952), pp. 208 - 14

(a) On the whole the evidence ... will not support the hypothesis of prices as the main, and still less as the sole, cause of the slump. Our knowledge of medieval prices is largely confined to grain, but in so far as other series are available they suggest that the fall in prices was highly compartmentalized. Thus it does not appear that prices for cloth or for iron, or indeed those for other commodities, fell at all, or fell in the same proportion as prices for agricultural products. (p. 208)

(b) Thus the prices for separate commodities did not move together....The prices for animal products in current coinage actually rose and were considerably higher in the period of 1401 to 1425 than in that of 1351 to 1375 .... Indeed, expressed in current prices, the series after 1351 continues the rising trend of the previous two centuries for at least another 125 years. (p. 208)

(c) Trade in butter may appear to the uninitiated too slight a foundation for any argument... Yet in spite of being cast on a small scale, it has turned out to be an important index of wider movements. For butter was a merchandise circulating over great distances and commanding an international price; and what is even more important is that it happened to be a semiluxury entering into popular consumption.... It is not necessary to know what Alfred Marshall said about the elasticity of the demand for bread to conclude that agricultural labourers were now better able to indulge in a little butter, however expensive. The price of butter was therefore highly responsive to changes in demand and supply, and was more sensitive as a barometer of markets than prices of more indispensable foods. It is therefore very significant that the price of butter and the price of grain diverged more widely than the prices of any other commodities. In the fourteenth and fifteenth centuries the butter prices rose very steeply, in both current coinage and in silver.. (pp. 209-10).

(d) Thus price movements there were, and from most of them important consequences followed; but they could not be entirely ascribed to monetary causes, and moreover they were not general. And price changes which are not 'general' but are mainly confined to grain, point to a factor which has already been shown to have operated in the direction in the early centuries of the Middle Ages, i.e. population.... (p. 213)

(e) A fall in population would also have, so to speak, a selective effect on prices, in that it would tend to lower the prices of agricultural products, which were previously being produced at

\footnotetext{
${ }^{106}$ A revised version of his contribution in: Carlo Cipolla, Jan Dhondt, Michael Postan, and Philippe Wolff, 'Rapports collectif', IXe congrès international des sciences historiques, Paris âout - septembre 1950, 1 (1950), 225-41).
} 
high and ever rising cost - or, to use the economist's terminology, under steeply diminishing returns - but would have little effect on commodities not greatly subject to diminishing returns, i.e. most industrial products. (p. 214)

(3) Michael Postan, The Medieval Economy and Society: An Economic History of Britain, 1100-1500 (Cambridge: Cambridge University Press, 1972), p. 238-9

(a) Most historians rightly assume that the use of various instruments of credit was more widespread and more sophisticated in the fifteenth century than it had been in the thirteenth. (p. 238)

(b) The pure logic of the monetary explanation demands that the effects of changes in the circulating medium should be felt throughout the economy, i.e. in the prices of all the goods sold and bought, since changes in money must be, so to speak, 'neutral' as between different commodities. It therefore follows that, if the price movement for different commodities diverged, monetary factors could not have been the sole of the main cause of price changes. (p. 239

(c) So much for the purely theoretical reasons why the currency could not be accepted as the sole or even the main factor behind the rise of prices in the thirteenth century and their decline in the fifteenth. (p. 238)

(d) An alternative 'real' hypothesis has in fact been suggested. The rising secular trend of grain prices could be accounted for by concomitant demographic trends. Population was increasing, or in other words the number of mouths was getting even greater. The output of agriculture, though expanding, could not keep pace with the increasing numbers to be fed. (p. 239) 


\section{List of Sources Cited:}

Abel, Wilhelm, Die Wüstungen des ausgehenden Mittelalters, Quellen und Forschungen zur Agrargeschichte, vol. 1 (Stuttgart: G. Fischer, 1976).

Abel, Wilhelm, Agrarkrisen und Agrarkonjunktur: Geschichte des Land- und Ernährungswirtschaft Mitteleuropas seit den hohen Mittlealter, 3rd edn. (Berlin: Parey, 1978), trans. by Olive Ordish as Agricultural Fluctuations in Europe from the Thirteenth to the Twentieth Centuries (London: Methuen, 1980); with a forward by Joan Thirsk.

Allen, Martin, 'The Volume of the English Currency, 1158 - 1470', Economic History Review, ${ }^{\text {nd }}$ ser., 54:4 (Nov. 2001), 595-611.

Allen, Martin, 'Silver Production and the Money Supply in England and Wales, 1086 - c. 1500', The Economic History Review, ${ }^{\text {nd }}$ ser., 64:1 (Feb. 2011), 114-31.

Allen, Martin, Mints and Money in Medieval England (Cambridge and New York: Cambridge University Press, 2012).

Ames, Edward, 'The Sterling Crisis of 1337-1339', Journal of Economic History, 25 (1965), 496-552.

Ashtor, Eliyahu, Les métaux précieux et la balance des payements du Proche-Orient à la basse époque (Paris: S.E.V.P.E.N , 1971).

Ashtor, Eliyahu, A Social and Economic History of the Near East in the Middle Ages (London: Collins, 1976).

Ashtor, Eliyahu, The Levant Trade in the Later Middle Ages (Princeton: Princeton University Press, 1983).

Bailey, Mark, 'Peasant Welfare in England, 1290-1348’, Economic History Review, 51:2 (May 1998), 22351.

Beveridge, William, 'Wages in the Winchester Manors', Economic History Review, 1st ser., 7:1 (Nov. 1936), 22-43.

Beveridge, William, 'Westminster Wages in the Manorial Era', Economic History Review, 2nd ser., 8:1 (1955), 18 - 35.

Blanchard, Ian, 'Population Change, Enclosure, and the Early Tudor Economy', Economic History Review, 2d ser., 23:3 (Dec. 1970), 427-45.

Blanchard, Ian, 'Lothian and Beyond: The Economy of the "English Empire” of David I', in Progress and Problems in Medieval England: Essays in Honour of Edward Miller, ed. Richard Britnell and John Hatcher (Cambridge: Cambridge University Press, 1996), pp. 23-45.

Blanchard, Ian, Mining, Metallurgy and Minting in the Middle Ages, 4 vols., vol. II: Afro-European Supremacy, 1125 - 1225 (African Gold Production and the First European Silver Production Long Cycle) (Stuttgart: Franz Steiner Verlag, 2001).

Blanchard, Ian, Mining, Metallurgy and Minting in the Middle Ages, 4 vols., vol. III: Continuing AfroEuropean Supremacy, 1250 - 1450 (Stuttgart: Franz Steiner Verlag, 2005).

Bovill, E. W., The Golden Trade of the Moors, 2nd edn. (Oxford: Oxford University Press, 1968).

Braunstein, Philippe, 'Innovations in Mining and Metal Production in Europe in the Late Middle Ages', Journal of European Economic History, 12 (1983), 573-9. 
Bridbury, Anthony, 'The Black Death’, Economic History Review, 2nd ser., 26:4 (Nov. 1973), 577-92.

Bridbury, Anthony, 'Before the Black Death’, Economic History Review, 2d ser., 30:3 (Aug. 1977), 393410.

Campbell, Bruce M.S., 'The Population of Early Tudor England: A Re-evaluation of the 1522 Muster Returns and the 1524 and 1525 Lay Subsidies’, Journal of Historical Geography, 7 (1981), 145-54.

Campbell, Bruce M.S., 'Agricultural Progress in Medieval England: Some Evidence from Eastern Norfolk', Economic History Review, 2nd ser., 36:1 (Feb. 1983), 26-46.

Campbell, Bruce M.S., 'Arable Productivity in Medieval England: Some Evidence from Norfolk', Journal of Economic History, 43:2 (June 1983), 379-404.

Campbell, Bruce M.S., 'Population Pressure, Inheritance, and the Land Market in a Fourteenth-Century Peasant Community', in Land, Kinship and Life-Cycle, ed. Richard Smith (Cambridge: Cambridge University Press, 1984), pp. 87 - 134.

Campbell, Bruce M.S., 'Land, Labour, Livestock, and Productivity Trends in English Seignioral Agriculture, 1208-1450', in Land, Labour, and Livestock: Historical Studies in European Agricultural Productivity, ed. Bruce M.S. Campbell and Mark Overton (Manchester: Manchester University Press, 1991), pp. 144-82.

Campbell, Bruce M.S., 'Matching Supply to Demand: Crop Production and Disposal by English Demesnes in the Century of the Black Death', Journal of Economic History, 57:4 (December 1997), 827-58.

Campbell, Bruce M.S., English Seigniorial Agriculture, 1250-1450, Cambridge Studies in Historical Geography 31 (Cambridge: Cambridge University Press, 2000), pp. 234, 247-8, 386-410.

Campbell, Bruce M.S., 'Nature as Historical Protagonist: Environment and Society in Pre-Industrial England’, The Economic History Review, 63:2 (May 2010), 281-314.

Campbell, Bruce M.S.; James A. Galloway, Derek Keene, and Margaret Murphy, A Medieval Capital and Its Grain Supply: Agrarian Production and Distribution in the London Region c. 1300, Historical Geography Research Series no. 30 (London: Institute of British Geographers, 1993).

Campbell, Bruce M.S.; and Mark Overton, 'A New Perspective on Medieval and Early Modern Agriculture: Six Centuries of Norfolk Farming, c.1250 - c.1850’ , Past \& Present, no. 141 (November 1993), pp. 38 105.

Cassell, Anthony, 'Boccaccio, Giovanni', in Dictionary of the Middle Ages, Vol. 2, ed. Joseph Strayer, et al (New York: Macmillan, 1983), pp. 277-90.

Cazelles, R. , 'Quelques reflexions à propos des mutations monétaires de la monnaie royale française (12951360)', Le moyen âge, 72 (1966), 83-105, and 251-78.

Cirkovic, Sima, 'The Production of Gold, Silver, and Copper in the Central Parts of the Balkans from the 13th to the 16th Century',both in Precious Metals in the Age of Expansion, ed. Hermann Kellenbenz, (Stuttgart, 1981), pp. 41-69.

Clark, Gregory, 'Labour Productivity in English Agriculture, 1300 - 1860', in Land, Labour, and Livestock: Historical Studies in European Agricultural Productivity, ed. Bruce M.S. Campbell and Mark Overton (Manchester: Manchester University Press, 1991), pp. 211-35.

Clark, Gregory, 'The Price History of English Agriculture, 1209 - 1914', Research in Economic History, 22 (2004), 125-81.

Clark, Gregory, 'Work, Wages and Living Conditions: Building Workers in England from Magna Carta to Tony Blair', in L'Edilizia prima della rivoluzione industriale, secc. XIII-XVIII, ed. Simonetta Caviococchi, Atti delle "Settimana di Studi" e altri convegni, no. 36, Istituto Internazionale di Storia Economica “F. 
Datini” (Florence: Le Monnier, 2005), pp. 889-932.

Clark, Gregory, 'The Condition of the Working Class in England, 1209-2004', Journal of Political Economy, 113:6 (December 2005), 1307-1340.

Clark, Gregory, 'The Long March of History: Farm Wages, Population, and Economic Growth: England, 1209-1869', The Economic History Review, 60:1 (February 2007), 97-135.

Cornwall, Julian, 'English Population in the Early Sixteenth Century', Economic History Review, 2nd ser., 23:1 (April 1970), 32-44.

Davis, Ralph, The Rise of the Atlantic Economies (Ithaca: Cornell University Press, 1973).

Day, John, 'The Great Bullion Famine of the Fifteenth Century’, Past and Present, no. 79 (May 1978), 1-54.

Day, John, ‘The Question of Monetary Contraction in Late Medieval Europe’, Nordisk Numismatisk Arsskrift: Nordic Numismatic Journal, 1981: Coinage and Monetary Circulation in the Baltic Area, c. 1350 - c. 1500 (Copenhagen, 1981), pp. 12-29; reprinted in John Day, The Medieval Market Economy (Oxford: Basil Blackwell, 1987), pp. 55-71.

De Moor, Tine; and Jan Luiten Van Zanden, 'Girl Power: the European Marriage Pattern and Labour Markets in the North Sea Region in the Late Medieval and Early Modern Period', The Economic History Review, 63:1 (February 2010), 1-33.

De Roover, Raymond, Money, Banking and Credit in Mediaeval Bruges: Italian Merchant-Bankers, Lombards, and Money Changers: A Study in the Origins of Banking (Cambridge, Mass., 1948).

De Roover, Raymond, 'The Organization of Trade,' in Cambridge Economic History of Europe, Vol. III: Economic Organization and Policies in the Middle Ages, ed. M.M. Postan and E.E. Rich (Cambridge: Cambridge University Press, 1963), pp. 42 - 118.

Duby, Georges, L'économie rurale et la vie des campagnes dans l'Occident médiéval (Paris, 1962), trans. by Cynthia Postan as Rural Economy and Country Life in the Medieval West (Philadelphia: University of Pennsylvania Press, 1968).

Dyer, Christopher, Lords and Peasants in a Changing Society: the Estates of the Bishopric of Worcester, 680 - 1540, Past and Present Publications (Cambridge and New York: Cambridge University Press, 1980).

Endrei, Walter, 'La productivité et la technique dans l'industrie textile du XIIIe au XVIIe siècle,' in Produttività e tecnologia nei secoli XII-XVII: Atti delle "Settimana di Studi” e altri convegni, no. 3, Istituto Internazionale di Storia Economica “F. Datini”, ed. Sara Mariotti (Florence: Le Monnier, 1981), pp. 253-62.

Farmer, David, 'Crop Yields, Prices and Wages in Medieval England', Studies in Medieval and Renaissance History, old series, 6 (1983), 117-55.

Farmer, David, 'Prices and Wages', in The Agrarian History of England and Wales, Vol. II: 1042-1350, ed. H. E. Hallam (Cambridge: Cambridge University Press, 1988), pp. 760-78, 811-17.

Farmer, David, 'Prices and Wages, 1350-1500', in The Agrarian History of England and Wales, Vol. III: 1348-1500, ed. Edward Miller (Cambridge: Cambridge University Press, 1991), pp. 467-90, 516-24.

Farmer, David, 'The Famuli in the Later Middle Ages', in Progress and Problems in Medieval England, ed. Richard Britnell and John Hatcher (Cambridge and New York: Cambridge University Press, 1996), pp. 21420.

Feavearyear, Albert, The Pound Sterling: a History of English Money, $2^{\text {nd }}$ edn. revised by E.V. Morgan (Oxford: Clarendon Press, 1963), pp. 13-18.

Fischer, David Hackett, The Great Wave: Price Revolutions and the Rhythm of History (Oxford and New York: Oxford University Press, 1996). 
Foreman-Peck, James, 'The Western European Marriage Pattern and Economic Development', Explorations in Economic History, 48:2 (April 2011), 292-309.

Girard, Albert, 'La guerre des monnaies,' Revue de synthèse 19 (1940-45), 83-101.

Graus, F., 'La crise monétaire du XIVe siècles', Revue belge de philologie et d'histoire, 29 (1951), 445-54.

Grunzweig, A., 'Les incidences internationales des mutations monétaires de Philippe le Bel', Le moyen âge, 59 (1953), 117-72.

Hajnal, John, 'European Marriage Patterns in Perspective', in Population in History: Essays in Historical Demography, ed. David V. Glass and D.E.C. Eversley (London: E. Arnold, 1965), pp. 101-46.

Hallam, Henry E., 'Population Movements in England, 1086-1350', in Agrarian History of England and Wales, vol. II: 1042-1350, ed. H. E. Hallam (Cambridge: Cambridge University Press, 1988), pp. 508-93.

Harvey, Barbara, 'The Population Trend in England Between 1300 and 1348', Transactions of the Royal Historical Society, 5th ser. 16 (1966), 23-42.

Harvey, Barbara, 'Introduction: the "Crisis” of the Early Fourteenth Century', in Before the Black Death: Studies in the 'Crisis' of the Early Fourteenth Century, ed. Bruce Campbell (Manchester: Manchester University Press, 1991), pp. 1 - 24.

Hatcher, John, Plague, Population, and the English Economy, 1348-1530 (London: MacMillan, 1977).

Hatcher, John, 'Mortality in the Fifteenth Century: Some New Evidence', Economic History Review, 2nd ser. 39:1 (Feb. 1986), 19-38.

Hatcher, John, 'England in the Aftermath of the Black Death', Past \& Present, no. 144 (1994), pp. 3-35.

Hatcher, John, 'The Great Slump of the Mid-Fifteenth Century,' in Progress and Problems in Medieval England: Essays in Honour of Edward Miller, ed. Richard Britnell and John Hatcher (Cambridge: Cambridge University Press, 1996), pp. 237-72.

Hatcher, John, 'Unreal Wages: Long-Run Living Standards and the 'Golden Age' of the Fifteenth Century', in Commercial Activity, Markets and Entrepreneurs in the Middle Ages: Essays in Honour of Richard Britnell, ed. Ben Dodds and Christian D. Liddy (Woodbridge: The Boydell Press, 2011), pp. 1-24.

Hatcher, John; A. J. Piper, and David Stone, 'Monastic Mortality: Durham Priory, 1395 - 1539', The Economic History Review, 59:4 (November 2006), 667-687.

Herlihy, David, Medieval and Renaissance Pistoia: The Social History of an Italian Town, 1200 -1430 (New Haven: Yale University Press, 1967).

Hilton, Rodney H., The Decline of Serfdom in Medieval England, Studies in Economic History series, 2nd rev. edn. (London: MacMillan, 1983).

Hinde, Andrew, England's Population: A History Since the Domesday Survey (London: Hodder Arnold, 2003).

Jordan, William C., The Great Famine: Northern Europe in the Early Fourteenth Century (Princeton: Princeton University Press, 1996).

Kershaw, Ian, 'The Great Famine and Agrarian Crisis in England, 1315-1322', Past and Present, no. 59 (May 1973), pp. 3-50

Kovacevic, D., 'Les mines d'or et d'argent en Serbie et en Bosnie médiévales’, Annales: E.S.C., 15 (1960), 248-58. 
Lane, Frederic C., 'The First Infidelities of the Venetian Lire', in The Medieval City, ed. H. A. Miskimin, David Herlihy, and A.L. Udovitch (New Haven and London: Yale University Press, 1977), pp. 43 - 64.

Langdon, John, Mills in the Medieval Economy: England, 1300 - 1540 (Oxford and New York: Oxford University Press, 2004).

Langdon, John, 'Waged Building Employment in Medieval England: Subsistence Safety Net or Demographic Trampoline?', in Survival and Discord in Medieval Society: Essays in Honour of Christopher Dyer, ed. Richard Goddard, John Langdon, and Miriam Müller, The Medieval Countryside no. 4 (Turnhout: Brepols Publishers, 2010), pp. 109-26.

Langdon, John, 'Minimum Wages and Unemployment Rates in Medieval England: The Case of Old Woodstock, Oxfordshire, 1256-1357', in Commercial Activity, Markets and Entrepreneurs in the Middle Ages: Essays in Honour of Richard Britnell, ed. Ben Dodds and Christian D. Liddy (Woodbridge: The Boydell Press, 2011), pp. 35-44.

Lopez, Robert S., 'Hard Times and Investment in Culture', in The Renaissance: Six Essays, ed. Wallace Ferguson, Metropolitan Museum of New York (New York: Harper and Row, 1962), pp. 29-52.

Lopez, R. S.; Harry Miskimin, and A.L. Udovitch, 'England to Egypt, 1350 - 1500: Long Term Trends and Long Distance Trade', in Studies in the Economic History of the Middle East: From the Rise of Islam to the Present Day, ed. M.. A. Cook (Oxford: Oxford University Press, 1970), pp. 93-128.

MacKay, Angus, Money, Prices and Politics in Fifteenth-Century Castile (London: Royal Historical Society, 1981).

Malthus, Robert Thomas, An Essay on the Principles of Population, $1^{\text {st }}$ edn. [London, 1798] (Oxford and New York: Oxford University Press, 1993).

Malthus, Robert Thomas, Principles of Political Economy: Considered With a View to Their Practical Application, $2^{\text {nd }}$ edn. [London, 1836] (New York: A. M. Kelly, 1968).

Mate, Mavis, 'High Prices in Early Fourteenth-Century England: Causes and Consequences', Economic History Review, 2nd ser., 28:1 (Feb. 1975), 1-16.

Mate, Mavis, 'The Role of Gold Coinage in the English Economy, 1338 - 1400', Numismatic Chronicle, $7^{\text {th }}$ ser., 18 (1978), 126-41.

Mayhew, Nicholas J., 'Numismatic Evidence and Falling Prices in the Fourteenth Century', Economic History Review, 2nd ser., 27:1 (1974), 1-15.

Mayhew, Nicholas J., 'Money and Prices in England from Henry II to Edward III', Agricultural History Review, 35:2 (1987), 121-32.

Mayhew, Nicholas J., 'From Regional to Central Minting, 1158-1464', in A New History of the Royal Mint, ed. Christopher Challis (Cambridge: Cambridge University Press, 1992), pp. 83-178.

Mayhew, Nicholas J., 'Population, Money Supply, and the Velocity of Circulation in England, 1300 - 1700', Economic History Review, 2nd ser., 48:2 (May 1995), 238-57.

Miller, Edward, 'War, Taxation, and the English Economy in the Late Thirteenth and Early Fourteenth Centuries', in War and Economic Development: Essays in Memory of David Joslin , ed. J.M. Winter (Cambridge: Cambridge University Press, 1975), pp. 11-32.

Miller, Edward, 'Introduction: Land and People', in Agrarian History of England and Wales, Vol. III: 13481500, ed. Edward Miller (Cambridge: Cambridge University Press, 1991), pp. 1-33.

Miller, Edward; and John Hatcher, Medieval England: Rural Society and Economic Change, 1086-1348, 
Social and Economic History of England (London: Longman, 1978).

Mills, F. C., Introduction to Statistics (New York: Henry Holt, 1956).

Miskimin, Harry A., 'Monetary Movements and Market Structures: Forces for Contraction in 14th and 15th Century England’, Journal of Economic History, 24 (1964), 470-90.

Miskimin, Harry A., The Economy of Early Renaissance Europe, 1300 - 1460 (Cambridge and New York: Cambridge University Press, 1975).

Miskimin, Harry, 'Money and Money Movements in France and England at the End of the Middle Ages', in Precious Metals in the Later Medieval and Early Modern Worlds, ed. John F. Richards (Durham, N.C.: Carolina Academic Press, 1983), pp. 79-96.

Mueller, Reinhold, “ "Chome l'ucciello di passegio”: la demande saisonnière des espèces et le marché des changes à Venise au moyen âge', in Études d'histoire monétaire, XIIe-XIXe siècles, ed. John Day (Lille: Presses universitaires de Lille, 1984), pp. 195-220.

Munro, John, Wool, Cloth, and Gold: The Struggle for Bullion in Anglo-Burgundian Trade, ca. 1340-1478 (Brussels and Toronto: Editions de l'Université de Bruxelles and University of Toronto Press, 1973).

Munro, John H., 'Bullionism and the Bill of Exchange in England, 1272-1663: A Study in Monetary Management and Popular Prejudice,' in The Dawn of Modern Banking, ed. Center for Medieval and Renaissance Studies UCLA (New Haven and London: Yale University Press, 1979), pp. 169-239.

Munro, John H., 'Mint Policies, Ratios, and Outputs in England and the Low Countries, 1335-1420: Some Reflections on New Data', The Numismatic Chronicle, 141 (1981), 71-116.

Munro, John H., 'Economic Depression and the Arts in the Fifteenth-Century Low Countries', Renaissance and Reformation, 19 (1983), 235-50.

Munro, John H., 'Bullion Flows and Monetary Contraction in Late-Medieval England and the Low Countries', in Precious Metals in the Later Medieval and Early Modern Worlds, ed. John F. Richards (Durham: Carolina Academic Press, 1983), pp. 97-158.

Munro, John H., 'Mint Outputs, Money, and Prices in Late-Medieval England and the Low Countries,' in Münzprägung, Geldumlauf und Wechselkurse/Minting, Monetary Circulation and Exchange Rates, ed. Eddy Van Cauwenberghe and Franz Irsigler, Trierer Historische Forschungen, 7: Akten des 8th International Economic History Congress, Section C-7, Budapest 1982 (Trier, 1984), pp. 31-122.

Munro, John H., 'Monnayage, monnaies de compte, et mutations monétaires au Brabant à la fin du moyen âge', in Études d'histoire monétaire, XIIe - XIXe siècles, ed. John Day, Études de l'Université de Paris VII et du Centre National des Lettres (Lille: Presses Universitaires de Lille, 1984), pp. 263-94.

Munro, John H., 'Deflation and the Petty Coinage Problem in the Late-Medieval Economy: The Case of Flanders, 1334 - 1484’, Explorations in Economic History, 25 (October 1988), 387-423.

Munro, John H., 'Industrial Transformations in the North-West European Textile Trades, c. 1290 - c. 1340: Economic Progress or Economic Crisis?' in Before the Black Death: Studies in the 'Crisis' of the Early Fourteenth Century, ed. Bruce M. S. Campbell (Manchester and New York: Manchester University Press, 1991), pp. 110 - 48.

Munro, John H., 'The Central European Mining Boom, Mint Outputs, and Prices in the Low Countries and England, 1450 - 1550', in Money, Coins, and Commerce: Essays in the Monetary History of Asia and Europe (From Antiquity to Modern Times), ed. Eddy H.G. Van Cauwenberghe (Leuven: Leuven University Press, 1991), pp. 119 - 83.

Munro, John H., 'The International Law Merchant and the Evolution of Negotiable Credit in Late-Medieval England and the Low Countries', in Banchi pubblici, banchi privati e monti di pietà nell'Europa 
preindustriale: amministrazione, tecniche operative e ruoli economici, ed. Dino Puncuh, Atti della Società Ligure di Storia Patria, Nouva Serie, Vol. XXXI (Genoa: Società Ligure di Storia Patria, 1991), pp. 49 - 80. Reprinted in John Munro, Textiles, Towns, and Trade: Essays in the Economic History of Late-Medieval England and the Low Countries, Variorum Collected Studies series CS 442 (Aldershot, Hampshire; and Brookfield, Vermont: Ashgate Publishing Ltd., 1994).

Munro, John H., Bullion Flows and Monetary Policies in England and the Low Countries, 1350-1500 (Aldershot: Variorum Ashgate, 1992).

Munro, John H., 'The Origins of the English 'New Draperies': The Resurrection of an Old Flemish Industry, 1270 - 1570,' in The New Draperies in the Low Countries and England, 1300 - 1800, ed. Negley B. Harte, Pasold Studies in Textile History no. 10 (Oxford and New York: Oxford University Press, 1997), pp. 35-127.

Munro, John H., 'The Symbiosis of Towns and Textiles: Urban Institutions and the Changing Fortunes of Cloth Manufacturing in the Low Countries and England, 1270 - 1570', The Journal of Early Modern History: Contacts, Comparisons, Contrasts, 3:1 (February 1999), 1-74.

Munro, John, Review of David Hackett Fischer, The Great Wave: Price Revolutions and the Rhythm of History (Oxford and New York, 1996), for EH.Net Review, 24 February 1999, online at: http://eh.net/book_reviews/great-wave-price-revolutions-and-rhythm-history

Munro, John H., 'The 'Industrial Crisis' of the English Textile Towns, 1290 - 1330', Thirteenth-Century England: VII, ed. Michael Prestwich, Richard Britnell, and Robin Frame (Woodbridge, UK: Boydell Academic Press, 1999), pp. 103-41.

Munro, John H., 'The Low Countries’ Export Trade in Textiles with the Mediterranean Basin, 1200-1600: A Cost-Benefit Analysis of Comparative Advantages in Overland and Maritime Trade Routes', The International Journal of Maritime History, 11:2 (Dec. 1999), 1 - 30.

Munro, John H., 'The "New Institutional Economics” and the Changing Fortunes of Fairs in Medieval and Early Modern Europe: the Textile Trades, Warfare, and Transaction Costs', Vierteljahrschrift für Sozial- und Wirtschaftsgeschichte, 88:1 (2001), 1 - 47.

Munro, John H., 'Gold, Guilds, and Government: The Impact of Monetary and Labour Policies on the Flemish Cloth Industry, 1390-1435’, Jaarboek voor middeleeuwse geschiedenis, 5 (2002), 153 - 205.

Munro, John H., 'Wage Stickiness, Monetary Changes, and Real Incomes in Late-Medieval England and the Low Countries, 1300 - 1500: Did Money Matter?’ Research in Economic History, 21 (2003), 185 - 297.

Munro, John H., 'Industrial Energy from Water-Mills in the European Economy, $5^{\text {th }}$ to $18^{\text {th }}$ Centuries: the Limitations of Power', in Economia ed energia, secoli XIII - XVIII, ed. Simonetta Cavaciocchi, Atti delle 'Settimane di Studi' e altrie Convegni, Istituto Internazionale di Storia Economica, 'Francesco Datini', vol. 34 (Florence: Le Monnier, 2003), pp. 223-69.

Munro, John H., 'Medieval Woollens: Textiles, Textile Technology, and Industrial Organisation, c. 800 1500', in The Cambridge History of Western Textiles, ed. David Jenkins, 2 vols. (Cambridge and New York: Cambridge University Press, 2003), Vol. I, pp. 181-227.

Munro, John H., 'Medieval Woollens: The Western European Woollen Industries and their Struggles for International Markets, c.1000 - 1500', in The Cambridge History of Western Textiles, 2 vols., ed. David Jenkins, (Cambridge and New York: Cambridge University Press, 2003), Vol. I, chapter 5, pp. 228-324, 37886 (bibliography).

Munro, John H., 'The Monetary Origins of the "Price Revolution:” South German Silver Mining, MerchantBanking, and Venetian Commerce, 1470-1540', in Global Connections and Monetary History, 1470 - 1800, ed. Dennis Flynn, Arturo Giráldez, and Richard von Glahn (Aldershot and Brookfield, Vt: Ashgate Publishing, 2003), pp. 1-34.

Munro, John H., 'The Medieval Origins of the Financial Revolution: Usury, Rentes, and Negotiablity', The 
International History Review, 25:3 (September 2003), 505-62.

Munro, John H., 'Builders' Wages in Southern England and the Southern Low Countries, 1346 -1500: A Comparative Study of Trends in and Levels of Real Incomes', in L'Edilizia prima della rivoluzione industriale, secoli XIII-XVIII, ed. Simonetta Cavaciocchi, Atti delle "Settimana di Studi” e altri convegni, no. 36, Istituto Internazionale di Storia Economica F. Datini (Florence: Le Monnier, 2005), pp. 1013-76

Munro, John H., 'South German Silver, European Textiles, and Venetian Trade with the Levant and Ottoman Empire, c. 1370 to c. 1720: A Non-Mercantilist Approach to the Balance of Payments Problem', in Relazioni economiche tra Europa e mondo islamico, secoli XIII - XVIII/Europe's Economic Relations with the Islamic World, $13^{\text {th }}-18^{\text {th }}$ Centuries, ed., Simonetta Cavaciocchi, Atti delle 'Settimana di Studi' e altri convegni, no. 38 (Florence: Le Monnier, 2007), pp. 907-62.

Munro, John H., 'Money, Prices, Wages, and "Profit Inflation” in Spain, the Southern Netherlands, and England during the Price Revolution era, ca. 1520 - ca. 1650', História e Economia: Revista Interdisciplinar, 4:1 (2008), 13-71.

Munro, John H., 'The Usury Doctrine and Urban Public Finances in Late-Medieval Flanders (1220 - 1550): Rentes (Annuities), Excise Taxes, and Income Transfers from the Poor to the Rich', in La fiscalità nell'economia Europea, secoli XIII - XVIII/ Fiscal Systems in the European Economy from the $13^{\text {th }}$ to the $18^{\text {th }}$ Centuries, ed. Simonetta Cavaciocchi, serie II: Atti delle 'Settimane de Studi' e altri Convegni no. 39 (Florence: Firenze University Press, 2008), pp. 973-1026.

Munro, John H., 'The Price Revolution', in The New Palgrave Dictionary of Economics, $2^{\text {nd }}$ edition, ed. Steven N. Durlauf and Lawrence E. Blume (London and New York: Palgrave Macmillan, 2008), vol. VI, pp. 631-34.

Munro, John H., 'Before and After the Black Death: Money, Prices, and Wages in Fourteenth-Century England', in New Approaches to the History of Late Medieval and Early Modern Europe: Selected Proceedings of Two International Conferences at The Royal Danish Academy of Sciences and Letters in Copenhagen in 1997 and 1999, ed. Troels Dahlerup and Per Ingesman (Copenhagen: The Royal Danish Academy of Sciences and Letters, 2009), pp. 335-364.

Munro, John H., 'The Technology and Economics of Coinage Debasements in Medieval and Early Modern Europe: with Special Reference to the Low Countries and England', in Money in the Pre-Industrial World: Bullion, Debasements and Coin Substitutes, ed. John Munro, Financial History Series no. 20 (London: Pickering \& Chatto Ltd., 2012), pp. 15-32, 185-89 (endnotes).

Munro, John H., 'The Late-Medieval Decline of English Demesne Agriculture: Demographic, Monetary, and Political-Fiscal Factors', in Town and Countryside in the Age of the Black Death: Essays in Honour of John Hatcher, ed. Mark Bailey and Stephen Rigby, The Medieval Countryside, vol. 12 (Turnhout: Brepols, 2012), pp. 299-348.

Nef, John, 'Silver Production in Central Europe, 1450-1618', Journal of Political Economy, 49 (1941), 57591.

Nef, John U., 'Mining and Metallurgy in Medieval Civilization', in Cambridge Economic History of Europe, Vol. II: Trade and Industry in the Middle Ages, ed. M.M. Postan and Edward Miller, revised edn. (Cambridge: Cambridge University Press, 1987), pp. 696-734.

Newfield, Timothy P., 'A Cattle Panzootic in Early Fourteenth-Century Europe’, British Agricultural History Review, 57:ii (2009), 155-90.

Nightingale, Pamela, 'Monetary Contraction and Mercantile Credit in Later Medieval England', Economic History Review, 2nd ser. 43:4 (November 1990), 560 - 75.

Nightingale, Pamela, 'The Growth of London in the Medieval English Economy', in Progress and Problems in Medieval England, ed. Richard Britnell and John Hatcher (Cambridge and New York: Cambridge University Press, 1996), pp. 89-106. 
Nightingale, Pamela, 'England and the European Depression of the Mid-Fifteenth Century,' The Journal of European Economic History, 26:3 (Winter 1997), 631-56.

Nightingale, Pamela, 'Some New Evidence of Crises and Trends of Mortality in Late Medieval England', Past and Present, no. 187 (May 2005), pp. 33-68.

Patterson, C. C. , 'Silver Stocks and Losses in Ancient and Medieval Times', Economic History Review, $2^{\text {nd }}$ ser., 25: 2 (May 1972), 205-35.

Paulinyi, Oszkar, 'The Crown Monopoly of the Refining Metallurgy of Precious Metals and the Technology of the Cameral Refineries in Hungary and Transylvania, 1325-1700, with Data and Output', in Precious Metals in the Age of Expansion, ed. Hermann Kellenbenz, (Stuttgart, 1981); pp. 27-39.

Penn, Simon; and Christopher Dyer, 'Wages and Earnings in Late Medieval England: Evidence from the Enforcement of the Labour Laws’, Economic History Review, ${ }^{\text {nd }}$ ser., 43:3 (Aug. 1990), 356-76.

Phelps Brown, E. Henry; and Sheila V. Hopkins, 'Seven Centuries of Building Wages', Economica, 22:87 (August 1955), 195-206, reprinted in Henry Phelps Brown and Sheila Hopkins, A Perspective of Wages and Prices (London: Methuen, 1981), pp. 1- 12.

Phelps Brown, E. Henry; and Sheila V. Hopkins, 'Seven Centuries of the Prices of Consumables, Compared with Builders’ Wage Rates', Economica, $23: 92$ (November 1956), 296-314: reprinted in E.H. Phelps Brown and Sheila V. Hopkins, A Perspective of Wages and Prices (London: Methuen, 1981), pp. 13-39 (with price indexes not in the original).

Poos, Lawrence ,'The Rural Population of Essex in the Later Middle Ages', Economic History Review, 2nd ser., 38:4 (Nov. 1985), 515-30.

Poos, Lawrence, A Rural Society after the Black Death: Essex, 1350-1525 (Cambridge: Cambridge University Press, 1991).

Poos, Lawrence, 'The Historical Demography of Northern Europe, 1400 - 1650', in New Approaches to the History of Late Medieval and Early Modern Europe: Selected Proceedings of Two International Conferences at the Royal Danish Academy of Sciences and Letters in Copenhagen in 1997 and 1999, ed. Troels Dohlerup and Per Ingesman (Copenhagen: The Royal Danish Academy of Sciences and Letters, 2009), pp. 365-96.

Postan, Michael, 'Credit in Medieval Trade', Economic History Review, 1st ser. 1 (1928), 234-61, reprinted. in Michael Postan, Medieval Trade and Finance (Cambridge: Cambridge University Press, 1973), pp. 1 - 27.

Postan, Michael, 'Private Financial Instruments in Medieval England', Vierteljahrschrift für Sozial- und Wirtschaftsgeschichte, 22 (1930), repr. in Postan, Medieval Trade, pp. 28-64.

Postan, Michael, 'The Economic and Political Relations of England with the Hanse from 1400 to 1475', in Studies in English Trade in the Fifteenth Century, ed. Eileen Power and Michael Postan (London, 1933; reprinted London: Routledge, 1966), pp. 91-154.

Postan, Michael, 'Some Economic Evidence of Declining Population in the Later Middle Ages,' Economic History Review, 2nd ser.. 2:1 (1950), 130-67, repr. as 'Some Agrarian Evidence of Declining Population in the Later Middle Ages', in Michael Postan, Essays on Medieval Agriculture and General Problems of the Medieval Economy (Cambridge: Cambridge University Press, 1973), pp. 186-213.

Postan, Michael, 'The Economic Foundations of Medieval Society’, Jahrbücher für Nationalökonomie 161 (1951), repr. in Postan, Essays, pp. 3-27 (a revised version of his contribution in: Carlo Cipolla, Jan Dhondt, Michael Postan, and Philippe Wolff, 'Rapports collectif', IXe congrès international des sciences historiques, Paris âout - septembre 1950, 1 (1950), 225-41).

Postan, Michael, 'The Trade of Medieval Europe: the North', in Cambridge Economic History of Europe, Vol. II: Trade and Industry in the Middle Ages, Michael Postan and E.E. Rich (Cambridge: Cambridge University Press, 1952), pp. 119-256; repr. with a few changes in the 2d ed.., ed. Michael Postan and Edward 
Miller (Cambridge: Cambridge University Press, 1987), Vol, II, pp. 168-305, and in Postan, Medieval Trade, pp. 92-31 (with bibliography).

Postan, Michael, 'Partnership in English Medieval Commerce', Rivista della società, 11 (1957), repr. in Postan, Medieval Trade, pp. 65-91.

Postan, Michael, 'Note’ (in response to:) W.C. Robinson, 'Money, Population, and Economic Change in Late Medieval Europe’, Economic History Review, 2nd ser., 12:1 (1959), 63-76, 77-82.

Postan, Michael, 'Medieval Agrarian Society in Its Prime: England', in The Cambridge Economic History, Vol. I: The Agrarian Life of the Middle Ages, $2^{\text {nd }}$ ed., ed. Michael Postan (Cambridge: Cambridge University Press, 1966), pp. 549-632.

Postan, Michael, The Medieval Economy and Society: An Economic History of Britain, 1100-1500 (Cambridge: Cambridge University Press, 1972).

Postan, Michael; and Jan Z. Titow, 'Heriots and Prices on Winchester Manors', Economic History Review, 2nd ser., 11: 3 (1959), 392-411, repr. in Postan, Essays, pp. 150-85.

Prestwich, Michael, 'Currency and the Economy of Early Fourteenth-Century England', in Edwardian Monetary Affairs, 1279-1344, ed. Nicholas Mayhew, BAR International Series, no. 36 (Oxford: British Archeological Reports, 1977), pp. 45-58.

Raftis, Ambrose, Tenure and Mobility: Studies in the Social History of the Medieval English Village (Toronto: Pontifical Institute of Mediaeval Studies, 1964).

Raftis, Ambrose, 'Peasants and the Collapse of the Manorial Economy on Some Ramsey Abbey Estates', in Progress and Problems in Medieval England, ed. Richard Britnell and John Hatcher (Cambridge and New York: Cambridge University Press, 1996), pp. 191-206.

Reynolds, Terry, Stronger Than a Hundred Men: A History of the Vertical Water Wheel, The Johns Hopkins Studies in the History of Technology, new series 7 (Baltimore: The Johns Hopkins University Press, 1983).

Ricardo, David, Principles of Political Economy and Taxation, with an introduction by Donald Wench [London, 1817] (London: Dent, 1982).

Rigby, Stephen H., 'Urban Population in Late Medieval England: the Evidence of the Lay Subsidies', The Economic History Review, 63:2 (May 2010), 393-417.

Rogers, James E. Thorold, A History of Agriculture and Prices in England From the Year After the Oxford Parliament (1259) to the Commencement of the Continental War (1793), 7 vols. (Oxford: Clarendon Press, 1866 - 1902).

Russell, Josiah Cox, British Medieval Population (Albequerque: University of New Mexico Press, 1948).

Russell, Josiah Cox, ‘The Preplague Population of England', Journal of British Studies, 5:2 (May1966), 1-21.

Schwartz, Anna Jacobson, 'Review', Journal of European Economic History, 3:1 (Spring 1974), 252-55: a review of Frank Spooner, International Economy and Monetary Movements in France, 1493 - 1725 (Cambridge, Mass.: Harvard University Press, 1972).

Slavin, Philip, 'The Fifth Rider of the Apocalypse: The Great Cattle Plague in England and Wales and its Economic Consequences, 1319 - 1350', in Le Interazioni fra economia e ambiente biologico nell'Europa preindustrielle seccoli XIII - XVIII/ Economic and Biological Interactions in Pre-Industrial Europe from the $13^{\text {th }}$ to the $18^{\text {th }}$ Centuries, ed. Simonetta Cavaciocchi, Atti delle "Settimana di Studi" e altri convegni, no. 40, Istituto Internazionale di Storia Economica “F. Datini” (Florence: Firenze University Press, 2010), pp. 16579.

Slicher-Van Bath, B.H., De agrarische geschiedenis van West Europa, 500 - 1850, trans. by Olive Ordish 
as The Agrarian History of Western Europe, A.D. 500-1850 (London: E. Arnold, 1963).

Smith, Richard, 'Demographic Developments in Rural England, 1300-48: a Survey', in Studies in the 'Crisis' of the Early Fourteenth Century, ed. Bruce Campbell (Manchester: Manchester University Press, 1991), pp. 25-77.

Spooner, Frank, International Economy and Monetary Movements in France, 1493 - 1725 (Cambridge, Mass.: Harvard University Press, 1972).

Spufford, Peter, Handbook of Medieval Exchange, Royal Historical Society Guides and Handbooks no. 13 (London, 1986).

Spufford, Peter, Money and Its Use in Medieval Europe (Cambridge, Cambridge University Press, 1988).

Spufford, Peter, 'The Debasement of the Coinage and its Effects on Exchange Rates and the Economy: in England in the 1540s, and in the Burgundian-Habsburg Netherlands in the 1480s', in Money in the PreIndustrial World: Bullion, Debasements, and Coin Substitutes, ed. John Munro (London: Pickering \& Chatto, 2012), pp. 68-85.

Stone, David, 'The Productivity of Hired and Customary Labour: Evidence from Wisbech Barton in the Fourteenth Century’, The Economic History Review, 50:4 (November 1997), 640-56.

Stone, David, 'Medieval Farm Management and Technological Mentalities: Hinderclay Before the Black Death’, The Economic History Review, 54:4 (November 2001), 612-38.

Stone, David, 'The Productivity and Management of Sheep in Late Medieval England', Agricultural History Review, 51:i (2003), 1-22.

Stone, David, Decision-Making in Medieval Agriculture (Oxford and New York: Oxford University Press, 2005).

Stuard, Susan M., 'Gravitas and Consumption', in Conflicted Identities and Multiple Masculinities: Men in the Medieval West, ed. Jacqueline Murray, Garland Medieval Casebooks vol. 25 (New York: Garland, 1999), pp. 215-42.

Stuard, Susan M., Gilding the Market: Luxury and Fashion in Fourteenth-Century Italy (Philadelphia: University of Pennsylvania Press, 2006).

Thompson, J. D. A., Inventory of British Coin Hoards, A.D. 600 - 1500 (Oxford: Royal Numismatic Society Publications, 1956).

Van der Wee, Herman, Growth of the Antwerp Market and the European Economy, 14th - 16th Centuries, 3 vols. (The Hague, 1963).

Van der Wee, Herman, 'Prijzen en lonen als ontwikkelingsvariabelen: Een vergelijkend onderzoek tussen Engeland en de Zuidelijke Nederlanden, 1400-1700', in Album aangeboden aan Charles Verlinden ter gelegenheid van zijn dertig jaar professoraat (Wetteren: Universum, 1975), pp. 413-47; reissued in English translation as 'Prices and Wages as Development Variables: A Comparison Between England and the Southern Netherlands, 1400-1700', Acta Historiae Neerlandicae, 10 (1978), 58-78; republished in Herman Van der Wee, The Low Countries in the Early Modern World, trans. by Lizabeth Fackelman (Cambridge and New York: Cambridge University Press and Variorum, 1993), pp. 223-41.

Van der Wee, Herman, 'Monetary, Credit, and Banking Systems', in Cambridge Economic History of Europe, vol. V: The Economic Organization of Early Modern Europe, ed. E.E. Rich and C.H. Wilson (Cambridge: Cambridge University Press, 1977), pp. 290-392.

Van der Wee, Herman, 'European Banking in the Middle Ages and Early Modern Period (476-1789)', in A History of European Banking, ed. Herman Van der Wee and G. Kurgan-Van Hentenrijk $2^{\text {nd }}$ edn. (Antwerp: Mercator Fonds, 2000), pp. 71 - 266. 
Westermann, Ekkehard, 'Die Bedeutung des Thüringer Saigerhandels für den mitteleuropäischen Handel an der Wende vom 15. zum 16. Jahrhundert', Jahrbuch für die Geschichte Mittel- und Ostdeutschlands, 21 (1972), 68-92.

Westermann, Ekkehard, 'Zur Silber- und Kupferproduktion Mitteleuropas vom 15. bis zum frühen 17. Jahrhundert: über Bedeutung und Rangfolge der Reviere von Schwaz, Mansfeld und Neusohl', Der Anschnitt: Zeitschrift für Kunst und Kultur im Bergbau, 38 (May-June 1986), 187 - 211.

Wrigley, Edward Anthony; R.S. Davies, J.E. Oeppen, and R. S. Schofield, English Population History from Family Reconstitution, Cambridge Studies in Population, Economy and Society in Past Time no. 32 (Cambridge and New York: Cambridge University Press, 1997). 
Table 1.

Values in Pence of the Main Commodity Groups in the English Basket of Consumables Price Index:

The Phelps Brown \& Hopkins Index Revised by John Munro

commodity values in pence sterling and their percentage shares of the total consumption basket

in quinquennial means, 1266-70 to 1516-20

with index numbers for the total basket: mean of 1451-75=100

Year
5 Year
Means

\begin{tabular}{cc} 
Grains \& & Meat \\
Drink & Fish \\
(Barley \& & Dairy \\
Hops) & \\
in & \\
\hline d sterling & in
\end{tabular}

Industrial:
Fuel,
Light
Textiles

Total

Index number

value of

the basket

in d sterling in d sterling

in d sterling in d sterling

1451-75=100
Munro

112.801d

sterling

\begin{tabular}{|c|c|c|c|c|c|c|c|c|}
\hline $1266-70$ & 45.693 & 30.945 & 19.073 & 95.711 & 84.850 & $47.74 \%$ & $32.33 \%$ & $19.93 \%$ \\
\hline 1271-75 & 60.300 & 40.026 & 18.942 & 119.267 & 105.733 & $50.56 \%$ & $33.56 \%$ & $15.88 \%$ \\
\hline 1276-80 & 51.566 & 41.440 & 19.822 & 112.827 & 100.023 & $45.70 \%$ & $36.73 \%$ & $17.57 \%$ \\
\hline 1281-85 & 61.669 & 40.321 & 16.658 & 118.648 & 105.184 & $51.98 \%$ & $33.98 \%$ & $14.04 \%$ \\
\hline 1286-90 & 41.581 & 36.477 & 14.386 & 92.444 & 81.953 & $44.98 \%$ & $39.46 \%$ & $15.56 \%$ \\
\hline $1291-95$ & 68.542 & 35.681 & 14.640 & 118.863 & 105.375 & $57.66 \%$ & $30.02 \%$ & $12.32 \%$ \\
\hline 1296-1300 & 57.257 & 39.703 & 16.162 & 113.122 & 100.285 & $50.62 \%$ & $35.10 \%$ & $14.29 \%$ \\
\hline 1301-05 & 49.163 & 37.105 & 17.146 & 103.414 & 91.679 & $47.54 \%$ & $35.88 \%$ & $16.58 \%$ \\
\hline 1306-10 & 58.224 & 43.141 & 15.641 & 117.006 & 103.728 & $49.76 \%$ & $36.87 \%$ & $13.37 \%$ \\
\hline 1311-15 & 56.096 & 50.895 & 17.588 & 124.580 & 110.443 & $45.03 \%$ & $40.85 \%$ & $14.12 \%$ \\
\hline 1316-20 & 100.359 & 54.667 & 19.318 & 174.344 & 154.560 & $57.56 \%$ & $31.36 \%$ & $11.08 \%$ \\
\hline 1321-25 & 78.288 & 50.301 & 18.846 & 147.434 & 130.704 & $53.10 \%$ & $34.12 \%$ & $12.78 \%$ \\
\hline 1326-30 & 54.550 & 44.100 & 19.467 & 118.116 & 104.712 & $46.18 \%$ & $37.34 \%$ & $16.48 \%$ \\
\hline 1331-35 & 60.016 & 44.551 & 18.507 & 123.074 & 109.108 & $48.76 \%$ & $36.20 \%$ & $15.04 \%$ \\
\hline 1336-40 & 41.997 & 41.660 & 17.025 & 100.682 & 89.256 & $41.71 \%$ & $41.38 \%$ & $16.91 \%$ \\
\hline 1341-45 & 41.585 & 38.899 & 15.999 & 96.482 & 85.533 & $43.10 \%$ & $40.32 \%$ & $16.58 \%$ \\
\hline 1346-50 & 51.221 & 41.597 & 20.055 & 112.873 & 100.064 & $45.38 \%$ & $36.85 \%$ & $17.77 \%$ \\
\hline 1351-55 & 68.656 & 48.430 & 25.575 & 142.661 & 126.472 & $48.13 \%$ & $33.95 \%$ & $17.93 \%$ \\
\hline 1356-60 & 59.555 & 48.017 & 25.636 & 133.209 & 118.092 & $44.71 \%$ & $36.05 \%$ & $19.25 \%$ \\
\hline 1361-65 & 77.057 & 53.063 & 25.518 & 155.637 & 137.976 & $49.51 \%$ & $34.09 \%$ & $16.40 \%$ \\
\hline 1366-70 & 73.347 & 53.496 & 27.085 & 153.928 & 136.460 & $47.65 \%$ & $34.75 \%$ & $17.60 \%$ \\
\hline 1371-75 & 60.083 & 56.820 & 26.743 & 143.646 & 127.345 & $41.83 \%$ & $39.56 \%$ & $18.62 \%$ \\
\hline 1376-80 & 48.326 & 50.545 & 25.087 & 123.958 & 109.891 & 38.99\% & $40.78 \%$ & $20.24 \%$ \\
\hline 1381-85 & 52.673 & 48.493 & 26.513 & 127.679 & 113.190 & $41.25 \%$ & $37.98 \%$ & $20.77 \%$ \\
\hline
\end{tabular}

\begin{tabular}{|c|c|c|c|c|c|c|c|c|}
\hline $1266-70$ & 45.693 & 30.945 & 19.073 & 95.711 & 84.850 & $47.74 \%$ & $32.33 \%$ & $19.93 \%$ \\
\hline 1271-75 & 60.300 & 40.026 & 18.942 & 119.267 & 105.733 & $50.56 \%$ & $33.56 \%$ & $15.88 \%$ \\
\hline $1276-80$ & 51.566 & 41.440 & 19.822 & 112.827 & 100.023 & $45.70 \%$ & $36.73 \%$ & $17.57 \%$ \\
\hline 1281-85 & 61.669 & 40.321 & 16.658 & 118.648 & 105.184 & $51.98 \%$ & $33.98 \%$ & $14.04 \%$ \\
\hline 1286-90 & 41.581 & 36.477 & 14.386 & 92.444 & 81.953 & $44.98 \%$ & $39.46 \%$ & $15.56 \%$ \\
\hline 1291-95 & 68.542 & 35.681 & 14.640 & 118.863 & 105.375 & $57.66 \%$ & $30.02 \%$ & $12.32 \%$ \\
\hline $1296-1300$ & 57.257 & 39.703 & 16.162 & 113.122 & 100.285 & $50.62 \%$ & $35.10 \%$ & $14.29 \%$ \\
\hline 1301-05 & 49.163 & 37.105 & 17.146 & 103.414 & 91.679 & $47.54 \%$ & $35.88 \%$ & $16.58 \%$ \\
\hline 1306-10 & 58.224 & 43.141 & 15.641 & 117.006 & 103.728 & $49.76 \%$ & $36.87 \%$ & $13.37 \%$ \\
\hline 1311-15 & 56.096 & 50.895 & 17.588 & 124.580 & 110.443 & $45.03 \%$ & $40.85 \%$ & $14.12 \%$ \\
\hline 1316-20 & 100.359 & 54.667 & 19.318 & 174.344 & 154.560 & $57.56 \%$ & $31.36 \%$ & $11.08 \%$ \\
\hline 1321-25 & 78.288 & 50.301 & 18.846 & 147.434 & 130.704 & $53.10 \%$ & $34.12 \%$ & $12.78 \%$ \\
\hline 1326-30 & 54.550 & 44.100 & 19.467 & 118.116 & 104.712 & $46.18 \%$ & $37.34 \%$ & 16.48 \\
\hline 1331-35 & 60.016 & 44.551 & 18.507 & 123.074 & 109.108 & $48.76 \%$ & $36.20 \%$ & 15.04 \\
\hline 1336-40 & 41.997 & 41.660 & 17.025 & 100.682 & 89.256 & $41.71 \%$ & $41.38 \%$ & $16.91 \%$ \\
\hline 1341-45 & 41.585 & 38.899 & 15.999 & 96.482 & 85.533 & $43.10 \%$ & $40.32 \%$ & $16.58^{\circ}$ \\
\hline 1346-50 & 51.221 & 41.597 & 20.055 & 112.873 & 100.064 & $45.38 \%$ & $36.85 \%$ & $17.77 \%$ \\
\hline 1351-55 & 68.656 & 48.430 & 25.575 & 142.661 & 126.472 & $48.13 \%$ & $33.95 \%$ & $17.93 \%$ \\
\hline 1356-60 & 59.555 & 48.017 & 25.636 & 133.209 & 118.092 & $44.71 \%$ & $36.05 \%$ & $19.25 \%$ \\
\hline 1361-65 & 77.057 & 53.063 & 25.518 & 155.637 & 137.976 & $49.51 \%$ & $34.09 \%$ & $16.40 \%$ \\
\hline 1366-70 & 73.347 & 53.496 & 27.085 & 153.928 & 136.460 & $47.65 \%$ & $34.75 \%$ & $17.60 \%$ \\
\hline 1371-75 & 60.083 & 56.820 & 26.743 & 143.646 & 127.345 & $41.83 \%$ & $39.56 \%$ & $18.62 \%$ \\
\hline 1376-80 & 48.326 & 50.545 & 25.087 & 123.958 & 109.891 & $38.99 \%$ & $40.78 \%$ & $20.24 \%$ \\
\hline 1381-85 & 52.673 & 48.493 & 26.513 & 127.679 & 113.190 & $41.25 \%$ & $37.98 \%$ & $20.77 \%$ \\
\hline
\end{tabular}

95.711
119.267
112.827
118.648
92.444
118.863
113.122
103.414
117.006
124.580
174.344
147.434
118.116
123.074
100.682
96.482
112.873
142.661
133.209
155.637
153.928
143.646
123.958
127.679

\begin{tabular}{|c|c|c|c|c|c|c|c|c|}
\hline $1266-70$ & 45.693 & 30.945 & 19.073 & 95.711 & 84.850 & $47.74 \%$ & $32.33 \%$ & $19.93 \%$ \\
\hline 1271-75 & 60.300 & 40.026 & 18.942 & 119.267 & 105.733 & $50.56 \%$ & $33.56 \%$ & $15.88 \%$ \\
\hline $1276-80$ & 51.566 & 41.440 & 19.822 & 112.827 & 100.023 & $45.70 \%$ & $36.73 \%$ & $17.57 \%$ \\
\hline 1281-85 & 61.669 & 40.321 & 16.658 & 118.648 & 105.184 & $51.98 \%$ & $33.98 \%$ & $14.04 \%$ \\
\hline 1286-90 & 41.581 & 36.477 & 14.386 & 92.444 & 81.953 & $44.98 \%$ & $39.46 \%$ & $15.56 \%$ \\
\hline 1291-95 & 68.542 & 35.681 & 14.640 & 118.863 & 105.375 & $57.66 \%$ & $30.02 \%$ & $12.32 \%$ \\
\hline $1296-1300$ & 57.257 & 39.703 & 16.162 & 113.122 & 100.285 & $50.62 \%$ & $35.10 \%$ & $14.29 \%$ \\
\hline 1301-05 & 49.163 & 37.105 & 17.146 & 103.414 & 91.679 & $47.54 \%$ & $35.88 \%$ & $16.58 \%$ \\
\hline 1306-10 & 58.224 & 43.141 & 15.641 & 117.006 & 103.728 & $49.76 \%$ & $36.87 \%$ & $13.37 \%$ \\
\hline 1311-15 & 56.096 & 50.895 & 17.588 & 124.580 & 110.443 & $45.03 \%$ & $40.85 \%$ & $14.12 \%$ \\
\hline 1316-20 & 100.359 & 54.667 & 19.318 & 174.344 & 154.560 & $57.56 \%$ & $31.36 \%$ & $11.08 \%$ \\
\hline 1321-25 & 78.288 & 50.301 & 18.846 & 147.434 & 130.704 & $53.10 \%$ & $34.12 \%$ & $12.78 \%$ \\
\hline 1326-30 & 54.550 & 44.100 & 19.467 & 118.116 & 104.712 & $46.18 \%$ & $37.34 \%$ & 16.48 \\
\hline 1331-35 & 60.016 & 44.551 & 18.507 & 123.074 & 109.108 & $48.76 \%$ & $36.20 \%$ & 15.04 \\
\hline 1336-40 & 41.997 & 41.660 & 17.025 & 100.682 & 89.256 & $41.71 \%$ & $41.38 \%$ & $16.91 \%$ \\
\hline 1341-45 & 41.585 & 38.899 & 15.999 & 96.482 & 85.533 & $43.10 \%$ & $40.32 \%$ & $16.58^{\circ}$ \\
\hline 1346-50 & 51.221 & 41.597 & 20.055 & 112.873 & 100.064 & $45.38 \%$ & $36.85 \%$ & $17.77 \%$ \\
\hline 1351-55 & 68.656 & 48.430 & 25.575 & 142.661 & 126.472 & $48.13 \%$ & $33.95 \%$ & $17.93 \%$ \\
\hline 1356-60 & 59.555 & 48.017 & 25.636 & 133.209 & 118.092 & $44.71 \%$ & $36.05 \%$ & $19.25 \%$ \\
\hline 1361-65 & 77.057 & 53.063 & 25.518 & 155.637 & 137.976 & $49.51 \%$ & $34.09 \%$ & $16.40 \%$ \\
\hline 1366-70 & 73.347 & 53.496 & 27.085 & 153.928 & 136.460 & $47.65 \%$ & $34.75 \%$ & $17.60 \%$ \\
\hline 1371-75 & 60.083 & 56.820 & 26.743 & 143.646 & 127.345 & $41.83 \%$ & $39.56 \%$ & $18.62 \%$ \\
\hline 1376-80 & 48.326 & 50.545 & 25.087 & 123.958 & 109.891 & $38.99 \%$ & $40.78 \%$ & $20.24 \%$ \\
\hline 1381-85 & 52.673 & 48.493 & 26.513 & 127.679 & 113.190 & $41.25 \%$ & $37.98 \%$ & $20.77 \%$ \\
\hline
\end{tabular}

Grains

Drink

(Barley)

Hops)

as percent

total

Meat
Fish
Dairy

as percent

total

Industrial:

Fuel,

Light

Textiles

as percent

total

\begin{tabular}{|c|c|c|c|c|c|c|c|c|}
\hline $1266-70$ & 45.693 & 30.945 & 19.073 & 95.711 & 84.850 & $47.74 \%$ & $32.33 \%$ & $19.93 \%$ \\
\hline 1271-75 & 60.300 & 40.026 & 18.942 & 119.267 & 105.733 & $50.56 \%$ & $33.56 \%$ & $15.88 \%$ \\
\hline $1276-80$ & 51.566 & 41.440 & 19.822 & 112.827 & 100.023 & $45.70 \%$ & $36.73 \%$ & $17.57 \%$ \\
\hline 1281-85 & 61.669 & 40.321 & 16.658 & 118.648 & 105.184 & $51.98 \%$ & $33.98 \%$ & $14.04 \%$ \\
\hline 1286-90 & 41.581 & 36.477 & 14.386 & 92.444 & 81.953 & $44.98 \%$ & $39.46 \%$ & $15.56 \%$ \\
\hline 1291-95 & 68.542 & 35.681 & 14.640 & 118.863 & 105.375 & $57.66 \%$ & $30.02 \%$ & $12.32 \%$ \\
\hline $1296-1300$ & 57.257 & 39.703 & 16.162 & 113.122 & 100.285 & $50.62 \%$ & $35.10 \%$ & $14.29 \%$ \\
\hline 1301-05 & 49.163 & 37.105 & 17.146 & 103.414 & 91.679 & $47.54 \%$ & $35.88 \%$ & $16.58 \%$ \\
\hline 1306-10 & 58.224 & 43.141 & 15.641 & 117.006 & 103.728 & $49.76 \%$ & $36.87 \%$ & $13.37 \%$ \\
\hline 1311-15 & 56.096 & 50.895 & 17.588 & 124.580 & 110.443 & $45.03 \%$ & $40.85 \%$ & $14.12 \%$ \\
\hline 1316-20 & 100.359 & 54.667 & 19.318 & 174.344 & 154.560 & $57.56 \%$ & $31.36 \%$ & $11.08 \%$ \\
\hline 1321-25 & 78.288 & 50.301 & 18.846 & 147.434 & 130.704 & $53.10 \%$ & $34.12 \%$ & $12.78 \%$ \\
\hline 1326-30 & 54.550 & 44.100 & 19.467 & 118.116 & 104.712 & $46.18 \%$ & $37.34 \%$ & 16.48 \\
\hline 1331-35 & 60.016 & 44.551 & 18.507 & 123.074 & 109.108 & $48.76 \%$ & $36.20 \%$ & 15.04 \\
\hline 1336-40 & 41.997 & 41.660 & 17.025 & 100.682 & 89.256 & $41.71 \%$ & $41.38 \%$ & $16.91 \%$ \\
\hline 1341-45 & 41.585 & 38.899 & 15.999 & 96.482 & 85.533 & $43.10 \%$ & $40.32 \%$ & $16.58^{\circ}$ \\
\hline 1346-50 & 51.221 & 41.597 & 20.055 & 112.873 & 100.064 & $45.38 \%$ & $36.85 \%$ & $17.77 \%$ \\
\hline 1351-55 & 68.656 & 48.430 & 25.575 & 142.661 & 126.472 & $48.13 \%$ & $33.95 \%$ & $17.93 \%$ \\
\hline 1356-60 & 59.555 & 48.017 & 25.636 & 133.209 & 118.092 & $44.71 \%$ & $36.05 \%$ & $19.25 \%$ \\
\hline 1361-65 & 77.057 & 53.063 & 25.518 & 155.637 & 137.976 & $49.51 \%$ & $34.09 \%$ & $16.40 \%$ \\
\hline 1366-70 & 73.347 & 53.496 & 27.085 & 153.928 & 136.460 & $47.65 \%$ & $34.75 \%$ & $17.60 \%$ \\
\hline 1371-75 & 60.083 & 56.820 & 26.743 & 143.646 & 127.345 & $41.83 \%$ & $39.56 \%$ & $18.62 \%$ \\
\hline 1376-80 & 48.326 & 50.545 & 25.087 & 123.958 & 109.891 & $38.99 \%$ & $40.78 \%$ & $20.24 \%$ \\
\hline 1381-85 & 52.673 & 48.493 & 26.513 & 127.679 & 113.190 & $41.25 \%$ & $37.98 \%$ & $20.77 \%$ \\
\hline
\end{tabular}




\begin{tabular}{|c|c|c|c|c|c|c|c|c|}
\hline $\begin{array}{l}\text { Year } \\
5 \text { Year } \\
\text { Means }\end{array}$ & $\begin{array}{c}\text { Grains \& } \\
\text { Drink } \\
\text { (Barley \& } \\
\text { Hops) } \\
\text { in d sterling }\end{array}$ & $\begin{array}{c}\text { Meat } \\
\text { Fish } \\
\text { Dairy } \\
\text { in d sterling }\end{array}$ & $\begin{array}{c}\text { Industrial: } \\
\text { Fuel, } \\
\text { Light } \\
\text { Textiles } \\
\text { in d sterling }\end{array}$ & $\begin{array}{c}\text { Total } \\
\text { value of } \\
\text { the basket }\end{array}$ & $\begin{array}{c}\text { Index number } \\
\text { 1451-75=100 } \\
\text { Munro } \\
\text { 112.801d } \\
\text { sterling }\end{array}$ & $\begin{array}{c}\text { Grains } \\
\text { Drink } \\
\text { (Barley) } \\
\text { Hops) } \\
\text { as percent } \\
\text { total }\end{array}$ & $\begin{array}{c}\text { Meat } \\
\text { Fish } \\
\text { Dairy } \\
\text { as percent } \\
\text { total }\end{array}$ & $\begin{array}{c}\text { Industrial: } \\
\text { Fuel, } \\
\text { Light } \\
\text { Textiles } \\
\text { as percent } \\
\text { total }\end{array}$ \\
\hline $1386-90$ & 44.449 & 47.393 & 22.348 & 114.191 & 101.233 & $38.93 \%$ & $41.50 \%$ & $19.57 \%$ \\
\hline 1391-95 & 51.005 & 44.093 & 22.161 & 117.259 & 103.953 & $43.50 \%$ & $37.60 \%$ & $18.90 \%$ \\
\hline $1396-1400$ & 53.816 & 49.719 & 21.277 & 124.812 & 110.648 & $43.12 \%$ & $39.83 \%$ & $17.05 \%$ \\
\hline 1401-05 & 58.498 & 47.457 & 21.118 & 127.073 & 112.653 & $46.04 \%$ & $37.35 \%$ & $16.62 \%$ \\
\hline 1406-10 & 52.646 & 49.584 & 21.768 & 123.998 & 109.927 & $42.46 \%$ & $39.99 \%$ & $17.55 \%$ \\
\hline 1411-15 & 48.726 & 50.018 & 23.375 & 122.119 & 108.261 & $39.90 \%$ & $40.96 \%$ & $19.14 \%$ \\
\hline $1416-20$ & 55.549 & 50.041 & 22.548 & 128.139 & 113.598 & $43.35 \%$ & $39.05 \%$ & $17.60 \%$ \\
\hline 1421-25 & 49.284 & 44.618 & 23.118 & 117.020 & 103.740 & $42.12 \%$ & $38.13 \%$ & $19.76 \%$ \\
\hline $1426-30$ & 55.745 & 47.861 & 23.419 & 127.025 & 112.610 & $43.89 \%$ & $37.68 \%$ & $18.44 \%$ \\
\hline 1431-35 & 53.252 & 47.420 & 22.418 & 123.090 & 109.122 & $43.26 \%$ & $38.52 \%$ & $18.21 \%$ \\
\hline $1436-40$ & 66.745 & 51.010 & 22.363 & 140.118 & 124.218 & $47.63 \%$ & $36.40 \%$ & $15.96 \%$ \\
\hline 1441-45 & 36.681 & 45.505 & 22.238 & 104.424 & 92.574 & $35.13 \%$ & $43.58 \%$ & $21.30 \%$ \\
\hline $1446-50$ & 44.519 & 48.482 & 21.199 & 114.200 & 101.241 & $38.98 \%$ & $42.45 \%$ & $18.56 \%$ \\
\hline 1451-55 & 47.534 & 46.528 & 20.712 & 114.774 & 101.750 & $41.42 \%$ & $40.54 \%$ & $18.05 \%$ \\
\hline $1456-60$ & 42.531 & 47.008 & 20.961 & 110.500 & 97.961 & $38.49 \%$ & $42.54 \%$ & $18.97 \%$ \\
\hline 1461-65 & 48.251 & 46.781 & 19.457 & 114.489 & 101.497 & $42.14 \%$ & $40.86 \%$ & $16.99 \%$ \\
\hline $1466-70$ & 46.067 & 48.073 & 21.729 & 115.869 & 102.720 & $39.76 \%$ & $41.49 \%$ & $18.75 \%$ \\
\hline 1471-75 & 45.745 & 42.228 & 20.397 & 108.370 & 96.072 & $42.21 \%$ & $38.97 \%$ & $18.82 \%$ \\
\hline $1476-80$ & 43.615 & 38.688 & 22.227 & 104.529 & 92.667 & $41.72 \%$ & $37.01 \%$ & $21.26 \%$ \\
\hline 1481-85 & 67.062 & 48.205 & 21.653 & 136.921 & 121.383 & $48.98 \%$ & $35.21 \%$ & $15.81 \%$ \\
\hline 1486-90 & 45.334 & 47.027 & 21.871 & 114.232 & 101.269 & $39.69 \%$ & $41.17 \%$ & $19.15 \%$ \\
\hline 1491-95 & 45.836 & 48.417 & 21.418 & 115.671 & 102.545 & $39.63 \%$ & $41.86 \%$ & $18.52 \%$ \\
\hline $1496-1500$ & 44.531 & 45.161 & 21.460 & 111.152 & 98.538 & $40.06 \%$ & $40.63 \%$ & $19.31 \%$ \\
\hline 1501-05 & 53.526 & 44.578 & 21.901 & 120.005 & 106.386 & $44.60 \%$ & $37.15 \%$ & $18.25 \%$ \\
\hline 1506-10 & 44.637 & 52.336 & 21.526 & 118.499 & 105.052 & $37.67 \%$ & $44.17 \%$ & $18.17 \%$ \\
\hline 1511-15 & 49.015 & 48.157 & 22.413 & 119.584 & 106.014 & $40.99 \%$ & $40.27 \%$ & $18.74 \%$ \\
\hline 1516-20 & 54.594 & 61.580 & 23.504 & 139.678 & 123.827 & $39.09 \%$ & $44.09 \%$ & $16.83 \%$ \\
\hline
\end{tabular}

See Table 2 below, for the index numbers for each of the seven major components in the basket, and Table 5 below for the quantities (by weight or volume) in each of these commodity groups. 


\section{Sources:}

Archives of the British Library of Economic and Political Science (London School of Economics), The Phelps Brown Papers, BOX Ia: 324

This significantly revised version should be compared with the the price indexes in the original version presented in E. Henry Phelps Brown and Sheila Hopkins, 'Seven Centuries of the Prices of Consumables, Compared with Builders' Wage Rates', Economica, 23:92 (November 1956), 296-314; reprinted in E.H. Phelps Brown and Sheila V. Hopkins, A Perspective of Wages and Prices (London, 1981), pp. 13-39 (with price indexes not in the original). That comparison may be seen in the fnal two columns (nos. 9 and 10) of the following Table 4. 
in quinquennial means: $1266-70$ to $1516-20$

$$
\text { mean of 1451-75 }=100
$$

index numbers for each commodity component of the basket and for the total basket

\begin{tabular}{|c|c|c|c|c|c|c|c|c|c|}
\hline $\begin{array}{c}\text { Years } \\
\text { Five-Year } \\
\text { Means }\end{array}$ & $\begin{array}{c}\text { Grains: } \\
\text { wheat, } \\
\text { rye } \\
\text { barley } \\
\text { peas } \\
\text { base } \\
\text { value } \\
\text { in d. }\end{array}$ & $\begin{array}{c}\text { Meat: } \\
\text { pigs } \\
\text { mutton } \\
\text { beef } \\
\\
\text { base } \\
\text { value } \\
\text { in d. }\end{array}$ & $\begin{array}{l}\text { Fish: } \\
\text { herring } \\
\text { cod }\end{array}$ & $\begin{array}{l}\text { Dairy } \\
\text { Products: } \\
\text { butter } \\
\text { cheese } \\
\\
\text { base } \\
\text { value } \\
\text { in d. }\end{array}$ & $\begin{array}{c}\text { Drink: } \\
\text { malt } \\
\text { hops }\end{array}$ & $\begin{array}{c}\text { Fuel/Light: } \\
\text { charcoal } \\
\text { candles } \\
\text { lamp oil } \\
\\
\text { base } \\
\text { value } \\
\text { in d. }\end{array}$ & $\begin{array}{c}\text { Textiles: } \\
\text { Woollens } \\
\text { Canvas } \\
\text { Linen } \\
\\
\text { base } \\
\text { value } \\
\text { in d. }\end{array}$ & $\begin{array}{c}\text { Total } \\
\text { Basket: } \\
\text { Munro } \\
\text { Revised } \\
\text { Index } \\
\text { base } \\
\text { value } \\
\text { in d. }\end{array}$ & $\begin{array}{l}\text { Phelps } \\
\text { Brown \& } \\
\text { Hopkins } \\
\text { Original } \\
\text { Index } \\
\text { numbers }\end{array}$ \\
\hline & 21.799 & 23.950 & 6.595 & 15.579 & 24.227 & 8.153 & 12.499 & 112.801 & \\
\hline 1266-70 & 93.495 & 69.780 & 26.764 & 80.027 & 104.481 & 137.304 & 63.040 & 84.850 & 78.667 \\
\hline 1271-75 & 129.148 & 106.889 & 25.766 & 81.694 & 132.691 & 129.628 & 66.995 & 105.733 & 104.200 \\
\hline $1276-80$ & 105.241 & 107.620 & 34.043 & 86.140 & 118.151 & 120.480 & 80.002 & 100.023 & 96.800 \\
\hline 1281-85 & 111.528 & 103.705 & 46.023 & 79.908 & 154.197 & 101.642 & 66.978 & 105.184 & 102.200 \\
\hline $1286-90$ & 79.081 & 91.023 & 33.411 & 80.065 & 100.476 & 92.576 & 54.718 & 81.953 & 80.600 \\
\hline 1291-95 & 139.541 & 85.490 & 36.166 & 82.300 & 157.360 & 92.038 & 57.099 & 105.375 & 107.200 \\
\hline $1296-1300$ & 108.480 & 101.148 & 45.871 & 79.936 & 138.728 & 97.346 & 65.813 & 100.285 & 102.400 \\
\hline 1301-05 & 93.544 & 94.467 & 34.119 & 78.503 & 118.760 & 114.210 & 62.685 & 91.679 & 92.400 \\
\hline 1306-10 & 117.048 & 109.551 & 44.633 & 89.608 & 135.013 & 116.569 & 49.105 & 103.728 & 110.600 \\
\hline 1311-15 & 116.607 & 123.486 & 56.592 & 112.898 & 126.625 & 125.881 & 58.613 & 110.443 & 115.200 \\
\hline 1316-20 & 194.864 & 132.724 & 65.478 & 119.145 & 238.913 & 127.026 & 71.704 & 154.560 & 162.000 \\
\hline 1321-25 & 164.702 & 111.064 & 57.876 & 127.634 & 174.948 & 131.758 & 64.843 & 130.704 & 138.200 \\
\hline 1326-30 & 101.931 & 105.950 & 43.723 & 101.686 & 133.446 & 128.719 & 71.789 & 104.712 & 111.000 \\
\hline 1331-35 & 110.302 & 110.021 & 50.913 & 95.281 & 148.479 & 123.733 & 67.359 & 109.108 & 114.200 \\
\hline 1336-40 & 84.730 & 96.346 & 58.293 & 94.622 & 97.109 & 115.110 & 61.129 & 89.256 & 94.400 \\
\hline $1341-45$ & 81.356 & 89.666 & 55.033 & 88.547 & 98.444 & 106.893 & 58.279 & 85.533 & 90.000 \\
\hline 1346-50 & 101.499 & 94.572 & 57.459 & 97.299 & 120.095 & 118.731 & 83.008 & 100.064 & 102.400 \\
\hline 1351-55 & 131.100 & 113.987 & 77.273 & 102.921 & 165.428 & 131.392 & 118.918 & 126.472 & 132.800 \\
\hline 1356-60 & 115.863 & 108.455 & 67.796 & 112.790 & 141.572 & 131.870 & 119.097 & 118.092 & 130.800 \\
\hline 1361-65 & 130.413 & 131.419 & 79.927 & 104.738 & 200.720 & 127.247 & 121.164 & 137.976 & 146.6 \\
\hline
\end{tabular}




\begin{tabular}{|c|c|c|c|c|c|c|c|c|c|}
\hline $\begin{array}{c}\text { Years } \\
\text { Five-Year } \\
\text { Means }\end{array}$ & $\begin{array}{c}\text { Grains: } \\
\text { wheat, } \\
\text { rye } \\
\text { barley } \\
\text { peas } \\
\text { base } \\
\text { value } \\
\text { in d. }\end{array}$ & $\begin{array}{c}\text { Meat: } \\
\text { pigs } \\
\text { mutton } \\
\text { beef }\end{array}$ & $\begin{array}{l}\text { Fish: } \\
\text { herring } \\
\text { cod }\end{array}$ & $\begin{array}{l}\text { Dairy } \\
\text { Products: } \\
\text { butter } \\
\text { cheese } \\
\text { base } \\
\text { value } \\
\text { in d. }\end{array}$ & $\begin{array}{l}\text { Drink: } \\
\text { malt } \\
\text { hops }\end{array}$ & $\begin{array}{c}\text { Fuel/Light: } \\
\text { charcoal } \\
\text { candles } \\
\text { lamp oil } \\
\\
\text { base } \\
\text { value } \\
\text { in d. }\end{array}$ & $\begin{array}{l}\text { Textiles: } \\
\text { Woollens } \\
\text { Canvas } \\
\text { Linen } \\
\text { base } \\
\text { value } \\
\text { in d. }\end{array}$ & $\begin{array}{c}\text { Total } \\
\text { Basket: } \\
\text { Munro } \\
\text { Revised } \\
\text { Index } \\
\text { base } \\
\text { value } \\
\text { in d. }\end{array}$ & $\begin{array}{l}\text { Phelps } \\
\text { Brown \& } \\
\text { Hopkins } \\
\text { Original } \\
\text { Index } \\
\text { numbers }\end{array}$ \\
\hline & 21.799 & 23.950 & 6.595 & 15.579 & 24.227 & 8.153 & 12.499 & 112.801 & \\
\hline 1366-70 & 150.487 & 131.607 & 80.875 & 106.830 & 167.344 & 143.980 & 122.784 & 136.460 & 146.200 \\
\hline 1371-75 & 133.638 & 143.653 & 86.182 & 107.403 & 127.757 & 153.580 & 113.786 & 127.345 & 135.400 \\
\hline 1376-80 & 96.219 & 118.580 & 87.597 & 105.066 & 112.898 & 139.896 & 109.466 & 109.891 & 110.600 \\
\hline 1381-85 & 104.029 & 110.890 & 82.897 & 105.709 & 123.810 & 136.484 & 123.102 & 113.190 & 113.200 \\
\hline 1386-90 & 83.336 & 108.055 & 98.061 & 96.590 & 108.486 & 129.251 & 94.497 & 101.233 & 102.400 \\
\hline 1391-95 & 96.639 & 106.471 & 109.181 & 73.130 & 123.578 & 131.190 & 91.735 & 103.953 & 106.200 \\
\hline 1396-1400 & 105.084 & 111.064 & 112.214 & 100.898 & 127.583 & 122.933 & 90.044 & 110.648 & 110.600 \\
\hline 1401-05 & 117.530 & 110.071 & 77.058 & 102.790 & 135.709 & 111.724 & 96.083 & 112.653 & 114.800 \\
\hline $1406-10$ & 108.229 & 106.555 & 112.425 & 106.878 & 119.921 & 109.523 & 102.721 & 109.927 & 111.200 \\
\hline 1411-15 & 91.411 & 105.599 & 114.787 & 110.132 & 118.876 & 120.772 & 108.239 & 108.261 & 108.000 \\
\hline 1416-20 & 114.066 & 103.055 & 129.702 & 107.879 & 126.654 & 123.370 & 99.931 & 113.598 & 112.800 \\
\hline 1421-25 & 94.999 & 93.213 & 122.294 & 91.331 & 117.948 & 131.817 & 98.984 & 103.740 & 102.000 \\
\hline 1426-30 & 107.222 & 99.581 & 116.106 & 104.979 & 133.620 & 122.182 & 107.674 & 112.610 & 112.600 \\
\hline 1431-35 & 110.106 & 106.078 & 81.498 & 106.810 & 120.734 & 120.031 & 101.071 & 109.122 & 108.600 \\
\hline 1436-40 & 148.525 & 109.585 & 114.857 & 110.342 & 141.862 & 118.457 & 101.656 & 124.218 & 122.000 \\
\hline 1441-45 & 75.504 & 96.624 & 109.282 & 97.290 & 83.469 & 116.799 & 101.740 & 92.574 & 92.800 \\
\hline 1446-50 & 97.399 & 106.245 & 96.604 & 106.978 & 96.123 & 333 & 8.617 & 101.241 & 101.000 \\
\hline 1451-55 & 102.327 & 100.600 & 100.898 & 101.294 & 104.133 & 3.918 & 97.930 & 101.750 & 100.400 \\
\hline 1456-60 & 94.082 & 101.948 & 100.070 & 102.652 & 90.899 & 101.898 & 101.243 & 97.961 & 97.000 \\
\hline 1461-65 & 103.681 & 101.972 & 96.494 & 102.675 & 105.874 & 92.172 & 95.549 & 101.497 & 102.800 \\
\hline $1466-70$ & 100.888 & 105.161 & 96.911 & 105.886 & 99.373 & 104.869 & 105.447 & 102.720 & 106.400 \\
\hline 1471-75 & 99.022 & 90.320 & 105.628 & 87.492 & 99.721 & 97.143 & 99.832 & 96.072 & 97.800 \\
\hline $1476-80$ & 107.053 & 83.116 & 100.299 & 78.102 & 83.701 & 93.890 & 116.589 & 92.667 & 91.000 \\
\hline 1481-85 & 148.173 & 110.420 & 84.839 & 103.760 & 143.487 & 101.428 & 107.085 & 121.383 & 129.800 \\
\hline 1486-90 & 109.393 & 106.973 & 87.146 & 100.521 & 88.693 & 93.340 & 114.103 & 101.269 & 102.800 \\
\hline 1491-95 & 100.342 & 111.863 & 79.611 & 105.115 & 98.909 & 81.642 & 118.110 & 102.545 & 103.400 \\
\hline $1496-1500$ & 103.260 & 102.599 & 84.438 & 96.411 & 90.899 & 86.299 & 115.406 & 98.538 & 96.800 \\
\hline 1501-05 & 128.266 & 100.137 & 90.008 & 94.097 & 105.526 & 93.464 & 114.259 & 106.386 & 110.600 \\
\hline 1506-10 & 104.004 & 119.888 & 92.077 & 112.656 & 90.666 & 88.070 & 114.780 & 105.052 & 99.800 \\
\hline 1511-15 & 121.826 & 108.781 & 93.701 & 102.219 & 92.698 & 95.511 & 117.022 & 106.014 & 108.600 \\
\hline
\end{tabular}




\begin{tabular}{|c|c|c|c|c|c|c|c|c|c|}
\hline $\begin{array}{c}\text { Years } \\
\text { Five-Year } \\
\text { Means }\end{array}$ & $\begin{array}{l}\text { Grains: } \\
\text { wheat, } \\
\text { rye } \\
\text { barley } \\
\text { peas } \\
\text { base } \\
\text { value } \\
\text { in d. }\end{array}$ & $\begin{array}{c}\text { Meat: } \\
\text { pigs } \\
\text { mutton } \\
\text { beef } \\
\\
\text { base } \\
\text { value } \\
\text { in } \mathrm{d} .\end{array}$ & $\begin{array}{l}\text { Fish: } \\
\text { herring } \\
\text { cod }\end{array}$ & $\begin{array}{c}\text { Dairy } \\
\text { Products: } \\
\text { butter } \\
\text { cheese } \\
\\
\text { base } \\
\text { value } \\
\text { in } \mathrm{d} .\end{array}$ & $\begin{array}{l}\text { Drink: } \\
\text { malt } \\
\text { hops }\end{array}$ & $\begin{array}{c}\text { Fuel/Light: } \\
\text { charcoal } \\
\text { candles } \\
\text { lamp oil } \\
\text { base } \\
\text { value } \\
\text { in d. }\end{array}$ & $\begin{array}{c}\text { Textiles: } \\
\text { Woollens } \\
\text { Canvas } \\
\text { Linen } \\
\\
\text { base } \\
\text { value } \\
\text { in d. }\end{array}$ & $\begin{array}{c}\text { Total } \\
\text { Basket: } \\
\text { Munro } \\
\text { Revised } \\
\text { Index } \\
\text { base } \\
\text { value } \\
\text { in d. }\end{array}$ & $\begin{array}{l}\text { Phelps } \\
\text { Brown \& } \\
\text { Hopkins } \\
\text { Original } \\
\text { Index } \\
\text { numbers }\end{array}$ \\
\hline & 21.799 & 23.950 & 6.595 & 15.579 & 24.227 & 8.153 & 12.499 & 112.801 & \\
\hline $1516-20$ & 116.520 & 148.352 & 84.375 & 131.498 & 120.502 & 99.745 & 122.987 & 123.827 & 120.600 \\
\hline
\end{tabular}

See Table 5 below for the commodity weights: i.e., the quantities, by weight or volume, in each of these commodity groups.

\section{Sources:}

Archives of the British Library of Economic and Political Science (LSE), The Phelps Brown Papers, BOX Ia: 324 
in quinquennial means: $1351-55$ to $1496-1500$

commodity values in Flemish pence groot and their percentage shares of the total basket

\begin{tabular}{|c|c|c|c|c|c|c|c|c|}
\hline $\begin{array}{l}\text { Years } \\
5 \text { yr } \\
\text { Means }\end{array}$ & $\begin{array}{l}\text { Grains } \\
\text { Total } \\
\text { Value } \\
\\
\text { in d groot } \\
\text { Flemish }\end{array}$ & $\begin{array}{c}\text { Dairy } \\
\text { Total } \\
\text { Value } \\
\text { in d groot } \\
\text { Flemish }\end{array}$ & $\begin{array}{c}\text { Textiles } \\
\text { Total } \\
\text { Value } \\
\text { in d groot } \\
\text { Flemish }\end{array}$ & $\begin{array}{c}\text { Basket } \\
\text { Consumables } \\
\text { Total Value } \\
\text { in d } \\
\text { groot } \\
\text { Flemish }\end{array}$ & $\begin{array}{c}\text { Commodity } \\
\text { Basket } \\
\text { Index } \\
1451-75= \\
100 \\
126.295 \\
\text { groot Flemish }\end{array}$ & $\begin{array}{c}\text { Grains } \\
\text { as per } \\
\text { cent of } \\
\text { total } \\
\text { basket } \\
\text { by value }\end{array}$ & $\begin{array}{c}\text { Dairy } \\
\text { as per } \\
\text { cent of } \\
\text { total } \\
\text { basket } \\
\text { by value }\end{array}$ & $\begin{array}{c}\text { Textiles } \\
\text { as per } \\
\text { cent of } \\
\text { total } \\
\text { basket } \\
\text { by value }\end{array}$ \\
\hline 1351-55 & 38.583 & 28.161 & 9.849 & 76.593 & 60.646 & $50.37 \%$ & $36.77 \%$ & $12.86 \%$ \\
\hline 1356-60 & 57.538 & 41.606 & 11.414 & 110.558 & 87.540 & $52.04 \%$ & $37.63 \%$ & $10.32 \%$ \\
\hline 1361-65 & 61.221 & 43.874 & 14.160 & 119.255 & 94.425 & $51.34 \%$ & $36.79 \%$ & $11.87 \%$ \\
\hline 1366-70 & 71.566 & 45.480 & 18.595 & 135.641 & 107.401 & $52.76 \%$ & $33.53 \%$ & $13.71 \%$ \\
\hline 1371-75 & 68.696 & 50.186 & 26.638 & 145.519 & 115.222 & $47.21 \%$ & $34.49 \%$ & $18.31 \%$ \\
\hline 1376-80 & 59.508 & 54.208 & 27.307 & 141.024 & 111.662 & $42.20 \%$ & $38.44 \%$ & $19.36 \%$ \\
\hline 1381-85 & 62.440 & 60.617 & 27.477 & 150.534 & 119.193 & $41.48 \%$ & $40.27 \%$ & $18.25 \%$ \\
\hline 1386-90 & 74.807 & 54.784 & 27.922 & 157.514 & 124.719 & $47.49 \%$ & $34.78 \%$ & $17.73 \%$ \\
\hline 1391-95 & 46.663 & 44.324 & 20.797 & 111.784 & 88.510 & $41.74 \%$ & $39.65 \%$ & $18.60 \%$ \\
\hline 1396-1400 & 52.259 & 41.151 & 19.998 & 113.407 & 89.796 & $46.08 \%$ & $36.29 \%$ & $17.63 \%$ \\
\hline 1401-05 & 53.643 & 36.034 & 22.133 & 111.810 & 88.531 & $47.98 \%$ & $32.23 \%$ & $19.79 \%$ \\
\hline 1406-10 & 65.192 & 40.670 & 27.077 & 132.939 & 105.261 & $49.04 \%$ & $30.59 \%$ & $20.37 \%$ \\
\hline 1411-15 & 52.776 & 41.279 & 26.315 & 120.370 & 95.309 & $43.84 \%$ & $34.29 \%$ & $21.86 \%$ \\
\hline 1416-20 & 62.415 & 46.754 & 26.447 & 135.616 & 107.381 & $46.02 \%$ & $34.48 \%$ & $19.50 \%$ \\
\hline 1421-25 & 63.542 & 51.094 & 27.044 & 141.680 & 112.182 & $44.85 \%$ & $36.06 \%$ & $19.09 \%$ \\
\hline $1426-30$ & 69.220 & 51.147 & 28.375 & 148.741 & 117.773 & $46.54 \%$ & $34.39 \%$ & $19.08 \%$ \\
\hline 1431-35 & 74.904 & 51.423 & 29.662 & 155.989 & 123.512 & $48.02 \%$ & $32.97 \%$ & $19.02 \%$ \\
\hline 1436-40 & 97.091 & 48.753 & 31.178 & 177.022 & 140.166 & $54.85 \%$ & $27.54 \%$ & $17.61 \%$ \\
\hline 1441-45 & 62.668 & 50.502 & 30.180 & 143.350 & 113.504 & $43.72 \%$ & $35.23 \%$ & $21.05 \%$ \\
\hline 1446-50 & 60.695 & 49.155 & 29.055 & 138.904 & 109.984 & $43.70 \%$ & $35.39 \%$ & $20.92 \%$ \\
\hline 1451-55 & 53.707 & 45.853 & 27.875 & 127.434 & 100.902 & $42.14 \%$ & $35.98 \%$ & $21.87 \%$ \\
\hline $1456-60$ & 74.315 & 47.918 & 26.612 & 148.845 & 117.855 & $49.93 \%$ & $32.19 \%$ & $17.88 \%$ \\
\hline $1461-65$ & 46.803 & 40.528 & 24.700 & 112.030 & 88.705 & $41.78 \%$ & $36.18 \%$ & $22.05 \%$ \\
\hline
\end{tabular}




\begin{tabular}{|c|c|c|c|c|c|c|c|c|}
\hline $\begin{array}{l}\text { Years } \\
5 \text { yr } \\
\text { Means }\end{array}$ & $\begin{array}{l}\text { Grains } \\
\text { Total } \\
\text { Value } \\
\text { in d groot } \\
\text { Flemish }\end{array}$ & $\begin{array}{c}\text { Dairy } \\
\text { Total } \\
\text { Value } \\
\text { in d groot } \\
\text { Flemish }\end{array}$ & $\begin{array}{c}\text { Textiles } \\
\text { Total } \\
\text { Value } \\
\text { in d groot } \\
\text { Flemish }\end{array}$ & $\begin{array}{c}\text { Basket } \\
\text { Consumables } \\
\text { Total Value } \\
\text { in d } \\
\text { groot } \\
\text { Flemish }\end{array}$ & $\begin{array}{c}\text { Commodity } \\
\text { Basket } \\
\text { Index } \\
\text { 1451-75= } \\
100 \\
126.295 \\
\text { groot Flemish }\end{array}$ & $\begin{array}{c}\text { Grains } \\
\text { as per } \\
\text { cent of } \\
\text { total } \\
\text { basket } \\
\text { by value }\end{array}$ & $\begin{array}{c}\text { Dairy } \\
\text { as per } \\
\text { cent of } \\
\text { total } \\
\text { basket } \\
\text { by value }\end{array}$ & $\begin{array}{c}\text { Textiles } \\
\text { as per } \\
\text { cent of } \\
\text { total } \\
\text { basket } \\
\text { by value }\end{array}$ \\
\hline 1466-70 & 52.607 & 45.204 & 24.089 & 121.900 & 96.520 & $43.16 \%$ & $37.08 \%$ & $19.76 \%$ \\
\hline 1471-75 & 54.337 & 43.824 & 23.103 & 121.264 & 96.017 & $44.81 \%$ & $36.14 \%$ & $19.05 \%$ \\
\hline $1476-80$ & 70.805 & 52.860 & 24.368 & 148.034 & 117.213 & $47.83 \%$ & $35.71 \%$ & $16.46 \%$ \\
\hline 1481-85 & 111.991 & 58.926 & 27.181 & 198.097 & 156.853 & $56.53 \%$ & $29.75 \%$ & $13.72 \%$ \\
\hline 1486-90 & 107.508 & 83.568 & 41.952 & 233.028 & 184.511 & $46.14 \%$ & $35.86 \%$ & $18.00 \%$ \\
\hline 1491-95 & 88.386 & 54.569 & 40.148 & 183.104 & 144.981 & $48.27 \%$ & $29.80 \%$ & $21.93 \%$ \\
\hline 1496-1500 & 46.277 & 41.677 & 38.663 & 126.617 & 100.255 & $36.55 \%$ & $32.92 \%$ & $30.54 \%$ \\
\hline
\end{tabular}

See Table 5 below for the commodity weights: i.e., the quantities, by weight or volume, in each of these commodity groups.

\section{Sources:}

Charles Verlinden, E. Scholliers, and J. Craeybeckx, eds., Documents pour l'histoire des prix et des salaires en Flandre et en Brabant/Dokumenten voor de geschiedenis van prijzen en lonen in Vlaanderen en Brabant, 2 vols., Rijksuniveristeit te Gent: Werken Uitgegeven door de Faculteit van de Letteren en Wijsbegeerte nos. 125, 136, 137 (Bruges, 1959-65), Vols. I, IIi., and II.ii

John Munro, 'Wage-Stickiness, Monetary Changes, and Real Incomes in Late-Medieval England and the Low Countries, 1300 - 1500: Did Money Matter?’ Research in Economic History, 21 (2003), 185 - 297.

Stadsarchief Gent, Stadsrekeningen, Reeks 400:7 - 35 (for cloth prices)

Note that these sources do not provide sufficient price data for this consumer price index (commodity basket) either before 1350 or after 1500 . 
Table 4.

Basket of Consumables Price Index for Flanders (Bruges and Ghent)

in quinquennial means: $1351-55$ to $1496-1500$

values in d. groot Flemish and in Index Numbers

mean of 1451-75 $=100$

Year




$1351-55$
$1356-60$
$1361-65$
$1366-70$
$1371-75$
$1376-80$
$1381-85$
$1386-90$
$1391-95$
$1396-1400$
$1401-05$
$1406-10$
$1411-15$
$1416-20$
$1421-25$
$1426-30$
$1431-35$
$1436-40$
$1441-45$
$1446-50$
$1451-55$
$1456-60$

Commodity
Basket
Index
$\mathbf{1 4 5 1 - 7 5}=$
$\mathbf{1 0 0}$
126.295
groot Flemish

76.593

110.558

119.255

135.641

145.519

141.024

150.534

157.514

111.784

113.407

111.810

132.939

120.370

135.616

141.680

148.741

155.989

177.022

143.350

138.904

127.434

148.845

Grains
Group
Index
$\mathbf{1 4 5 1 - 7 5}=$
$\mathbf{1 0 0}$
56.354
groot Flemish

$$
\begin{array}{r}
60.646 \\
87.540 \\
94.425 \\
107.401 \\
115.222 \\
111.662 \\
119.193 \\
124.719 \\
88.510 \\
89.796 \\
88.531 \\
105.261 \\
95.309 \\
107.381 \\
112.182 \\
117.773 \\
123.512 \\
140.166 \\
113.504 \\
109.984 \\
100.902 \\
117.855
\end{array}
$$

Dairy
Group
Index
$\mathbf{1 4 5 1 - 7 5 =}$
$\mathbf{1 0 0}$
44.665
groot Flemish

68.466

102.100

108.636

126.994

121.901

105.597

110.799

132.745

82.803

92.733

95.190

115.682

93.652

110.755

112.756

122.830

132.917

172.289

111.205

107.703

95.302

131.873

\begin{tabular}{cc} 
& Textiles \\
Group \\
Index \\
1451-75= \\
$\mathbf{1 0}$ \\
\multicolumn{2}{c}{ 100 } \\
25.276 \\
groot Flemish \\
mish \\
63.048 \\
93.151 & 38.968 \\
98.228 & 45.160 \\
101.825 & 56.023 \\
112.359 & 73.568 \\
121.366 & 105.388 \\
135.714 & 108.038 \\
122.655 & 108.711 \\
99.235 & 110.470 \\
92.132 & 82.282 \\
80.675 & 79.118 \\
91.056 & 87.565 \\
92.417 & 107.127 \\
104.677 & 104.114 \\
114.392 & 104.636 \\
114.511 & 106.998 \\
115.130 & 112.262 \\
109.153 & 117.353 \\
113.067 & 123.350 \\
110.051 & 119.403 \\
102.660 & 114.952 \\
107.281 & 110.282 \\
& 105.288
\end{tabular}


Year

Basket of
Consumables
Total Value
in d
groot
Flemish

1461-65

1466-70

1471-75

1476-80

1481-85

1486-90

1491-95

1496-1500

Commodity
Basket
Index
$\mathbf{1 4 5 1 - 7 5 =}$
$\mathbf{1 0 0}$
126.295
groot Flemish

112.030

121.900

121.264

148.034

198.097

233.028

183.104

126.617

Grains
Group
Index
$\mathbf{1 4 5 1 - 7 5 =}$
$\mathbf{1 0 0}$
56.354
groot Flemish

88.705

96.520

96.017

117.213

156.853

184.511

144.981

100.255

\section{Dairy \\ Group}

Index

1451-75=

100

44.665

groot Flemish
Textiles

Group

Index

1451-75=

100

25.276

groot Flemish
83.052
93.351
96.422
125.644
198.728
190.773
156.841
82.119

90.737

101.206

98.116

118.347

131.927

187.098

122.174

93.309

See Table 5 below for the commodity weights: i.e., the quantities, by weight or volume, in each of these commodity groups.

\section{Sources:}

See the sources for Table 3. 
Table 5.

Basket of Consumables Commodity Price Indexes

For England and Flanders (1275 - 1500)

component weights and values for the base period

mean of prices $1451-75=100$

\section{ENGLAND}

Commodity

$\begin{array}{cccccc}\text { Amount Unit } & \begin{array}{c}\text { Metric } \\ \text { Measure }\end{array} & \begin{array}{c}\text { Percent } \\ \text { by PBH } \\ \text { weights }\end{array} & \begin{array}{c}\text { Value } \\ \text { in d } \\ \text { sterling }\end{array} & \begin{array}{c}\text { Percent } \\ \text { by value } \\ \text { (Munro) }\end{array}\end{array}$

Farinaceous

Wheat

Rye

Barley

Peas

Sub-total

Drink

barley (or malt)

Total Farinaceous

Meat, Fish, Dairy

Sheep
Pigs
Herrings
Butter
Cheese

$\begin{array}{llllll}1.250 & \text { bu } & 45.461 & & 9.967 & 8.84 \% \\ 1.000 & \text { bu } & 36.369 & & 6.279 & 5.57 \% \\ 0.500 & \text { bu } & 18.184 & & 2.606 & 2.31 \% \\ 0.667 & \text { bu } & 24.243 & & 2.947 & 2.61 \% \\ & & & & & \\ 3.417 & \text { bu } & 124.257 & \mathbf{2 0 . 0 0 \%} & \mathbf{2 1 . 7 9 9} & \mathbf{1 9 . 3 3 \%}\end{array}$

4.500 bu 163.659

7.917 bu 287.917

$42.50 \%$

$\begin{array}{rrrrrr}0.500 & \text { no. } & 0.050 & & 8.532 & 7.56 \% \\ 0.500 & \text { no. } & 0.050 & 21.00 \% & 15.418 & 13.67 \% \\ 40.000 & \text { no. } & 40.000 & 4.00 \% & 6.595 & 5.85 \% \\ 10.000 & \text { lb. } & 4.536 & & 10.238 & 9.08 \% \\ 10.000 & \text { lb. } & 4.536 & 12.50 \% & 5.341 & 4.74 \%\end{array}$

\section{FLANDERS}
Amount Unit Value in Percent in d gr. by value Flemish

$\begin{array}{rrrr}45.461 & \text { l. } & 13.279 & 10.51 \% \\ 36.369 & \text { l. } & 7.062 & 5.59 \% \\ 18.184 & \text { l. } & 2.867 & 2.27 \% \\ 24.243 & \text { l. } & 7.341 & 5.81 \% \\ & & & \\ \mathbf{1 2 4 . 2 5 7} & \text { l. } & \mathbf{3 0 . 5 4 9} & \mathbf{2 4 . 1 9 \%} \\ & & & \\ \mathbf{1 6 3 . 6 5 9} & \text { l. } & \mathbf{2 5 . 8 0 5} & \mathbf{2 0 . 4 3 \%} \\ \mathbf{2 8 7 . 9 1 7} & \text { l. } & \mathbf{5 6 . 3 5 4} & \mathbf{4 4 . 6 2 \%}\end{array}$

\begin{tabular}{rrrr}
\multicolumn{5}{c}{$\mathrm{kg}$} & & \\
& $\mathrm{no}$. & & \\
13.610 & $\mathrm{~kg}$ & 36.087 & $28.57 \%$ \\
13.610 & $\mathrm{~kg}$ & 8.578 & $6.79 \%$
\end{tabular}




\section{ENGLAND}

$\begin{array}{lrc}\text { Commodity } & \text { Amount } & \text { Unit } \\ & & \\ \text { Sub-total } & & \\ & & \\ \text { Industrial } & & \\ & & \\ \text { Charcoal } & 4.250 & \mathrm{bu} \\ \text { Candles } & 2.750 & \mathrm{lb} . \\ \text { Lamp Oil } & 0.500 & \mathrm{pt} \\ \text { Canvas/Linen } & 0.670 & \mathrm{yd} \\ \text { Shirting } & 0.500 & \mathrm{yd} \\ \text { Coarse Woollens } & 0.330 & \mathrm{yd}\end{array}$

Sub-total

TOTAL

$$
\begin{aligned}
& \mathrm{bu}=\text { bushels } \\
& \mathrm{lb}=\text { pound } \\
& \mathrm{pt}=\text { pint } \\
& \text { yd = yard } \\
& \mathrm{l} .=\text { litre } \\
& \mathrm{kg}=\text { kilogram } \\
& \mathrm{m} .=\text { metre }
\end{aligned}
$$

\section{FLANDERS}

$\begin{array}{ccc}\text { Amount Unit } & \begin{array}{l}\text { Value in } \\ \text { in d gr. } \\ \text { Flemish }\end{array}\end{array}$

27.220

$44.665 \quad 35.37 \%$

$\begin{array}{rrr} & 3.813 & 3.38 \% \\ & 3.475 & 3.08 \% \\ 7.50 \% & 0.865 & 0.77 \% \\ & 2.757 & 2.44 \% \\ & 2.718 & 2.41 \% \\ 12.50 \% & 7.023 & 6.23 \% \\ & & \\ \mathbf{2 0 . 0 0 \%} & \mathbf{2 0 . 6 5 1} & \mathbf{1 8 . 3 1 \%} \\ & & \\ \mathbf{1 0 0 . 0 0 \%} & \mathbf{1 1 2 . 8 0 1} & \mathbf{1 0 0 . 0 0 \%}\end{array}$

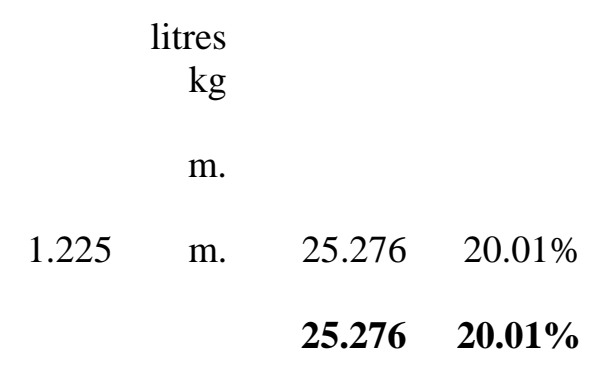

$126.295 \quad 100.00 \%$

\section{Sources:}

Archives of the British Library o Economic and Political Science (LSE), The Phelps Brown Papers, BOX Ia: 324

E. Henry Phelps Brown and Sheila V. Hopkins, 'Seven Centuries of the Prices of Consumables, Compared with Builders' Wage Rates', Economica, 23:92 (November 1956), 296-314; reprinted in E.H. Phelps Brown and Sheila V. Hopkins, A Perspective of Wages and Prices (London, 1981), pp. 13-39 (with price indexes not in the original).

John H. Munro, 'Wage-Stickiness, Monetary Changes, and Real Incomes in Late-Medieval England and the Low Countries, 1300 - 1500: Did Money Matter?’ Research in Economic History, 21 (2003), 185 - 297, esp. Table 1, p. 231. 
Table 6.

$\begin{array}{lc}\text { Year } & \text { Phelps Brown } \\ \text { Michaelmas } & \text { \& Hopkins } \\ \text { Five-year } & \text { CPI } \\ \text { period } & \begin{array}{c}\text { (Munro) } \\ \text { revised } \\ \text { version) }\end{array}\end{array}$

$\begin{array}{lr}\mathbf{1 2 6 6 - 7 0} & 84.850 \\ \mathbf{1 2 7 1 - 7 5} & 105.733 \\ \mathbf{1 2 7 6 - 8 0} & 100.023 \\ \mathbf{1 2 8 1 - 8 5} & 105.184 \\ \mathbf{1 2 8 6 - 9 0} & 81.953 \\ \mathbf{1 2 9 1 - 9 5} & 105.375 \\ \mathbf{1 2 9 6 - 1 3 0 0} & 100.285 \\ \mathbf{1 3 0 1 - 0 5} & 91.679 \\ \mathbf{1 3 0 6 - 1 0} & 103.728 \\ \mathbf{1 3 1 1 - 1 5} & 110.443 \\ \mathbf{1 3 1 6 - 2 0} & 154.560 \\ \mathbf{1 3 2 1 - 2 5} & 130.704 \\ \mathbf{1 3 2 6 - 3 0} & 104.712 \\ \mathbf{1 3 3 1 - 3 5} & 109.108 \\ \mathbf{1 3 3 6 - 4 0} & 89.256 \\ \mathbf{1 3 4 1 - 4 5} & 85.533 \\ \mathbf{1 3 4 6 - 5 0} & 100.064 \\ \mathbf{1 3 5 1 - 5 5} & 126.472 \\ \mathbf{1 3 5 6 - 6 0} & 118.092 \\ \mathbf{1 3 6 1 - 6 5} & 137.976 \\ \mathbf{1 3 6 6 - 7 0} & 136.460\end{array}$

National Means of Manorial Agricultural Wages in England

In quinquennial means: $1266-70$ to $1496-1500$

in pence and in index numbers, for nominal and real wages

Index: Mean of 1451-75 = 100
REAPING AND BINDING GRAINS per acre of grains
THRESHING AND WINNOWING GRAINS Piece rates per razed quarter ( 8 bushels)

Reaping \&
Binding
per acre
of grains
Index:
1451-75=100
$9.966 d$

9.966d

\section{Real Wage Index \\ RWI $=$ NWI/CP harmonic means $1451-75=100$}

46.970

43.636

48.000

51.758

45.455

48.606

49.576

52.606

56.606

64.121

66.667

62.667

65.576

64.242

59.394

60.970

70.788

79.030

65.939

80.606

83.273

$$
\begin{aligned}
& 55.367 \\
& 41.228 \\
& 47.142 \\
& 49.043 \\
& 55.327 \\
& 45.995 \\
& 49.445 \\
& 57.296 \\
& 54.342 \\
& 58.012 \\
& 42.366 \\
& 47.913 \\
& 62.282 \\
& 58.730 \\
& 66.710 \\
& 71.277 \\
& 66.331 \\
& 62.273 \\
& 55.741 \\
& 58.291 \\
& 60.776
\end{aligned}
$$

Threshing \&
Winnowing
razed quarter
of grains
pence

3.502

3.648

3.802

3.909

4.057

4.595

4.519

4.982

4.508

4.648

5.025

5.488

5.111

5.358

5.358

5.402

5.832

6.262

5.746

6.252

6.671

$\begin{array}{cc}\text { Threshing \& } & \text { Real Wage } \\ \text { Winnowing } & \text { Index } \\ \text { razed quarter } & \text { RWI=NWI/CPI } \\ \text { of grains } & \text { harmonic } \\ \text { Index: } & \text { means } \\ \begin{array}{c}1451-75=100 \\ 10.366 d\end{array} & 1451-75=100 \\ & \end{array}$

$\begin{array}{ll}33.787 & 39.707 \\ 35.188 & 33.315 \\ 36.676 & 35.575 \\ 37.714 & 34.224 \\ 39.132 & 47.621 \\ 44.322 & 41.587 \\ 43.596 & 43.269 \\ 48.059 & 51.808 \\ 43.492 & 41.802 \\ 44.841 & 40.427 \\ 48.474 & 30.356 \\ 52.938 & 40.421 \\ 49.305 & 46.875 \\ 51.692 & 46.586 \\ 51.692 & 57.893 \\ 52.107 & 60.912 \\ 56.259 & 55.738 \\ 60.411 & 46.468 \\ 55.429 & 46.704 \\ 60.307 & 43.542 \\ 64.355 & 46.566\end{array}$


REAPING AND BINDING GRAINS

per acre of grains
THRESHING AND WINNOWING GRAINS

Piece rates per razed quarter (8 bushels)

$\begin{array}{llc}\text { Year } & \text { Phelps Brown } & \text { Reaping \& } \\ \text { Michaelmas } & \text { \& Hopkins } & \text { Binding } \\ \text { Five-year } & \text { CPI } & \text { per acre } \\ \text { period } & \begin{array}{c}\text { (Munro) } \\ \text { revised } \\ \text { version) }\end{array} & \text { of grains } \\ & \text { pence }\end{array}$

1371-75

1376-80

1381-85

1386-90

1391-95

1396-1400

1401-05

1406-10

1411-15

1416-20

1421-25

1426-30

1431-35

1436-40

1441-45

1446-50

1451-55

1456-60

1461-65

1466-70

1471-75

1476-80

1481-85

1486-90

1491-95

1496-1500
127.345

109.891

113.190

101.233

103.953

110.648

112.653

109.927

108.261

113.598

103.740

112.610

109.122

124.218

92.574

101.241

101.750

97.961

101.497

102.720

96.072

92.667

121.383

101.269

102.545

98.538

Reaping \&
Binding
per acre
of grains

Index:

1451-75=100

9.966d

\subsection{0}

9.954

9.072

9.205

8.734

8.734

9.241

9.918

10.038

9.857

9.362

9.048

9.386

9.561

10.981

9.942

9.821

10.268

10.026

10.026

\subsection{1}

99.879

91.030

92.364

87.636

87.636

92.727

99.515

100.727

98.909

93.939

90.788

94.182

95.939

110.182

99.758

98.545

103.030

100.606

Real Wage
Index
RWI=NWI/CPI
harmonic
means
1451-75=100

Threshing \&

Winnowing

razed quarter

of grains

pence

65.891

90.925

78.986

91.244

83.473

77.934

82.430

90.550

93.009

86.918

90.009

79.884

86.265

77.596

118.832

98.561

96.827

105.470

114.032

7.414
7.704
8.038

7.500

7.414

7.962

8.436

8.726

7.812

8.920

8.317

8.221

8.070

10.254

9.415

8.920

9.447

10.448

10.674

10.340

10.921

100.606

82.833*

$\begin{array}{cc}\text { Threshing \& } & \text { Real Wage } \\ \text { Winnowing } & \text { Index } \\ \text { razed quarter } & \text { RWI=NWI/CPI } \\ \text { of grains } & \text { harmonic } \\ \text { Index: } & \text { means } \\ \text { 1451-75=100 } & 1451-75=100 \\ 10.366 d & \end{array}$

71.518

55.280

67.418

68.007

71.425

68.700

69.165

69.795

76.101

69.618

74.925

77.243

70.570

71.231

77.342

97.297

84.038

88.540

102.479

101.542

96.804

109.663 
* arithmetic means based on nominal wages for 1480-81 only

\section{Sources:}

David Farmer, ‘Crop Yields, Prices and Wages in Medieval England’, Studies in Medieval and Renaissance History, old series, 6(1983), 117-55; David Farmer, 'Prices and Wages', in The Agrarian History of England and Wales, Vol. II: 1042-1350, ed. H. E. Hallam (Cambridge: Cambridge University Press, 1988), pp. 760-78, 811-17; David Farmer, 'Prices and Wages, 1350-1500', in The Agrarian History of England and Wales, Vol. III: 1348-1500, ed. Edward Miller (Cambridge: Cambridge University Press, 1991), pp. 467-90, 516-24.

Note that Farmer's wage data do not go beyond 1500; and there are few agricultural wages available from manorial sources after ca. 1450. 
Part A: for Carpenters and Masons (Masters)

In quinquennial means, $1266-70$ to $1496-1500$

in pence per day and in index numbers, for nominal and real wages

Index: Mean of 1451-75 $=100$

\section{CARPENTERS: MANORIAL}

in pence per day

Year
Michaelmas
Five-year
period

1266-70

1271-75

1276-80

1281-85

1286-90

1291-95

1296-1300

1301-05

1306-10

1311-15

1316-20

1321-25

1326-30

1331-35

1336-40

1341-45

1346-50

1351-55

1356-60

1361-65

Phelps Brown
\& Hopkins
CPI
(Munro )
revised
version)

Carpenter
solo
per day
in
pence

Carpenter
solo
per day

Index:
1451-75=100
$5.508 d$

Real Wage
Index
RWI=NWI/CPI
harmonic
means

$\begin{array}{ll}51.489 & 58.407 \\ 58.195 & 54.083 \\ 43.192 & 44.665 \\ 43.533 & 41.241 \\ 45.920 & 54.590 \\ 49.102 & 46.535 \\ 56.149 & 55.482 \\ 49.784 & 53.739 \\ 52.398 & 50.588 \\ 51.944 & 47.006 \\ 60.582 & 38.920 \\ 58.991 & 45.063 \\ 54.444 & 52.063 \\ 58.877 & 54.050 \\ 56.945 & 63.373 \\ 54.444 & 63.364 \\ 59.786 & 59.090 \\ 63.992 & 50.181 \\ 71.835 & 60.774 \\ 76.040 & 55.102\end{array}$

84.850
105.733
100.023
105.184
81.953
105.375
100.285
91.679
103.728
110.443
154.560
130.704
104.712
109.108
89.256
85.533
100.064
126.472
118.092
137.976

MASONS: MANORIAL

in pence per day

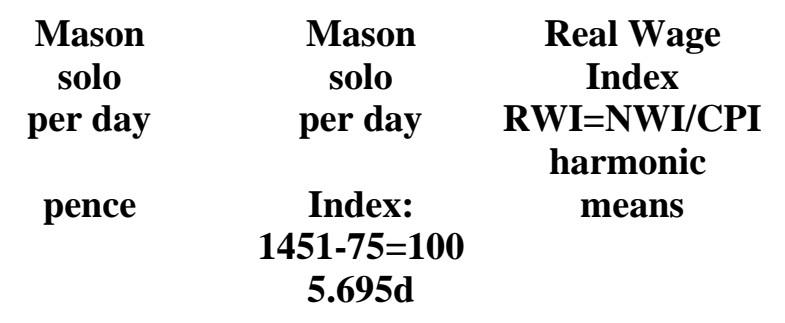




\begin{tabular}{|c|c|c|c|c|c|c|c|}
\hline $\begin{array}{l}\text { Year } \\
\text { Michaelmas } \\
\text { Five-year } \\
\text { period }\end{array}$ & $\begin{array}{l}\text { Phelps Brown } \\
\text { \& Hopkins } \\
\text { CPI } \\
\text { (Munro ) } \\
\text { revised } \\
\text { version) }\end{array}$ & $\begin{array}{l}\text { Carpenter } \\
\text { solo } \\
\text { per day } \\
\text { in } \\
\text { pence }\end{array}$ & $\begin{array}{c}\text { Carpenter } \\
\text { solo } \\
\text { per day } \\
\\
\text { Index: } \\
\text { 1451-75=100 } \\
5.508 d\end{array}$ & $\begin{array}{c}\text { Real Wage } \\
\text { Index } \\
\text { RWI=NWI/CPI } \\
\text { harmonic } \\
\text { means }\end{array}$ & $\begin{array}{c}\text { Mason } \\
\text { solo } \\
\text { per day } \\
\text { pence }\end{array}$ & $\begin{array}{c}\text { Mason } \\
\text { solo } \\
\text { per day } \\
\\
\text { Index: } \\
\text { 1451-75=100 } \\
5.695 d\end{array}$ & $\begin{array}{c}\text { Real Wage } \\
\text { Index } \\
\text { RWI=NWI/CPI } \\
\text { harmonic } \\
\text { means }\end{array}$ \\
\hline 1366-70 & 136.460 & 4.332 & 78.654 & 57.697 & 4.215 & 74.003 & 53.838 \\
\hline 1371-75 & 127.345 & 4.194 & 76.154 & 59.602 & 4.488 & 78.793 & 60.605 \\
\hline 1376-80 & 109.891 & 4.194 & 76.154 & 69.304 & 4.713 & 82.745 & 75.299 \\
\hline 1381-85 & 113.190 & 4.319 & 78.427 & 69.095 & 4.788 & 84.062 & 73.735 \\
\hline 1386-90 & 101.233 & 4.207 & 76.381 & 75.388 & 4.269 & 74.961 & 73.418 \\
\hline 1391-95 & 103.953 & 4.269 & 77.518 & 74.465 & 4.528 & 79.511 & 75.455 \\
\hline 1396-1400 & 110.648 & 4.276 & 77.631 & 70.193 & 4.324 & 75.919 & 68.453 \\
\hline 1401-05 & 112.653 & 4.639 & 84.224 & 74.644 & 4.651 & 81.667 & 71.885 \\
\hline 1406-10 & 109.927 & 4.733 & 85.929 & 77.377 & 5.054 & 88.732 & 80.270 \\
\hline 1411-15 & 108.261 & 4.344 & 78.882 & 72.716 & 4.849 & 85.140 & 77.680 \\
\hline 1416-20 & 113.598 & 4.582 & 83.201 & 73.118 & 5.296 & 92.983 & 80.323 \\
\hline 1421-25 & 103.740 & 4.657 & 84.565 & 81.328 & 5.429 & 95.318 & 91.175 \\
\hline $1426-30$ & 112.610 & 4.970 & 90.248 & 80.267 & 5.313 & 93.282 & 82.142 \\
\hline 1431-35 & 109.122 & 4.826 & 87.634 & 79.953 & 4.979 & 87.415 & 78.991 \\
\hline $1436-40$ & 124.218 & 5.396 & 97.977 & 79.105 & 5.569 & 97.773 & 77.873 \\
\hline 1441-45 & 92.574 & 5.064 & 91.953 & 99.365 & 5.224 & 91.726 & 98.609 \\
\hline 1446-50 & 101.241 & 5.283 & 95.931 & 94.597 & 5.531 & 97.114 & 95.690 \\
\hline 1451-55 & 101.750 & 5.321 & 96.613 & 94.979 & 5.592 & 98.192 & 96.412 \\
\hline 1456-60 & 97.961 & 5.590 & 101.500 & 103.403 & 5.490 & 96.396 & 98.141 \\
\hline 1461-65 & 101.497 & 5.390 & 97.863 & 96.414 & 5.487 & 96.336 & 94.422 \\
\hline $1466-70$ & 102.720 & 5.446 & 98.886 & 96.013 & 5.954 & 104.538 & 101.697 \\
\hline 1471-75 & 96.072 & 5.791 & 105.138 & 109.609 & 5.954 & 104.538 & 108.307 \\
\hline 1476-80 & 92.667 & 5.878 & 106.729 & 114.305 & 5.886 & 103.341 & 111.453 \\
\hline 1481-85 & 121.383 & 5.584 & 101.387 & 83.131 & 5.333 & 93.641 & 76.871 \\
\hline 1486-90 & 101.269 & 5.834 & 105.933 & 104.362 & 5.647 & 99.150 & 97.402 \\
\hline 1491-95 & 102.545 & 5.872 & 106.615 & 103.621 & 5.797 & 101.784 & 99.217 \\
\hline 1496-1500 & 98.538 & 5.647 & 102.523 & 103.518 & 5.575 & 97.892 & 99.135 \\
\hline
\end{tabular}

\section{Sources:}

David L. Farmer, 'Crop Yields, Prices and Wages in Medieval England’, Studies in Medieval and Renaissance History, 6 (1983), 117-55. 
David L. Farmer, 'Prices and Wages', in H. E. Hallam, ed., The Agrarian History of England and Wales, Vol. II: $1042-1350$ (Cambridge, 1988 ), pp. 760-78, 811-17.

David L. Farmer, 'Prices and Wages, 1350-1500', in Edward Miller, ed., The Agrarian History of England and Wales, Vol. III: 1348-1500 (Cambridge, 1991), pp. 467-90, 516-24.

Note that Farmer's wage data do not go beyond 1500. 
Table 8.

Year

Michaelmas

Five-year

period

1266-70

1271-75

1276-80

1281-85

1286-90

1291-95

1296-1300

1301-05

1306-10

1311-15

1316-20

1321-25

1326-30

1331-35

1336-40

1341-45

1346-50

1351-55

1356-60

1361-65

1366-70

National Means of Manorial Industrial Wages in England

Part B: For Thatchers and Slaters (Masters and Servants)

In quinquennial means, $1266-70$ to $1496-1500$

in pence per day and in index numbers, for nominal and real wages

Index: Mean of 1451-75 $=100$

THATCHER \& MATES: MANORIAL

in pence per day

Phelps Brown
\& Hopkins
CPI
(Munro )
revised
version)

84.850

105.733

100.023

105.184

81.953

105.375

100.285

91.679

103.728

110.443

154.560

130.704

104.712

109.108

89.256

85.533

100.064

126.472

118.092

137.976

136.460

Thatcher
\& mate
per day
pence

$\begin{array}{cc}\text { Thatcher } & \text { Real Wage } \\ \text { \& mate } & \text { Index } \\ \text { per day } & \text { RWI=NWI/CPI } \\ & \text { harmonic } \\ \text { Index: } & \text { means } \\ \text { 1451-75=100 } & \\ 9.108 d & \end{array}$

2.715
3.258
3.093
4.002
3.433
3.620
3.531
3.613
3.523
3.987
4.107
3.882
3.531
3.792
3.882
3.553
4.204
4.682
4.608
5.333
5.685

29.81

35.767

33.960

43.939

37.697

39.750

38.765

39.668

38.683

43.775

45.089

42.625

38.765

41.639

42.625

39.011

46.156

51.413

50.591

58.558

62.418
SLATER/TILERS \& MATES: MANORIAL in pence per day

Slater/Tiler
\& mate
per day
pence

Slater/Tiler
\& mate
per day

Index:
1451-75=100
$9.698 d$
Real Wage Index RWI $=$ NWI/CPI harmonic means


THATCHER \& MATES: MANORIAL in pence per day

$\begin{array}{lcc}\text { Year } & \text { Phelps Brown } & \text { Thatcher } \\ \text { Michaelmas } & \text { \& Hopkins } & \text { \& mate } \\ \text { Five-year } & \text { CPI } & \text { per day } \\ \text { period } & \begin{array}{c}\text { (Munro ) } \\ \text { revised } \\ \text { version) }\end{array} & \text { pence } \\ & & \end{array}$

1371-75

1376-80

1381-85

1386-90

1391-95

1396-1400

1401-05

1406-10

1411-15

1416-20

1421-25

1426-30

1431-35

1436-40

1441-45

1446-50

1451-55

1456-60

1461-65

1466-70

1471-75

1476-80

1481-85

1486-90

1491-95

1496-1500
127.345

109.891

113.190

101.233

103.953

110.648

112.653

109.927

108.261

113.598

103.740

112.610

109.122

124.218

92.574

101.241

101.750

97.961

101.497

102.720

96.072

92.667

121.383

101.269

102.545

98.538

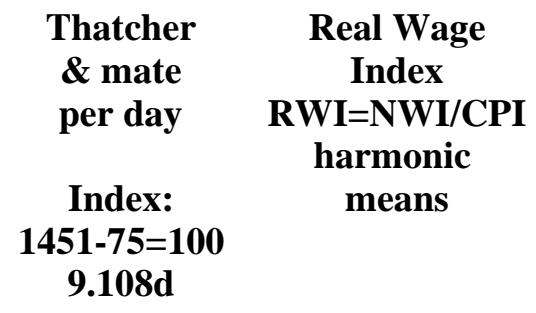

5.887

6.066

6.171

6.119

6.313

6.253

6.567

6.829

6.552

6.882

6.171

7.667

7.443

8.774

8.767

8.804

9.260

9.544

9.013

9.013

8.707

9.500

9.986

9.874

9.175

64.635
66.606
67.756
67.181
69.317
68.660
72.109
74.984
71.945
75.558
67.756
84.182
81.718
96.337
96.255
96.666
101.675
104.796
98.965
98.965
95.598
104.304
109.642
108.410
100.745

60.747

59.676

66.293

66.240

62.010

63.613

67.938

66.124

66.445

65.038

74.515

74.736

77.113

102.614

95.316

99.135

106.531

97.505

96.344

99.170

103.620

105.206

104.366

100.799
SLATER/TILERS \& MATES: MANORIAL

in pence per day

Slater/Tiler
\& mate
per day
pence

$\begin{array}{cc}\text { Slater/Tiler } & \text { Real Wage } \\ \text { \& mate } & \text { Index } \\ \text { per day } & \text { RWI=NWI/CPI } \\ & \text { harmonic } \\ \text { Index: } & \text { means } \\ \text { 1451-75=100 } & \\ \text { 9.698d } & \end{array}$

79.063

72.711

77.530

77.256

74.135

76.106

83.005

80.924

80.596

85.852

86.180

84.209

87.166

92.860

93.736

94.393

98.445

99.978

97.569

103.373

100.635

102.278

94.722

92.532

92.970

92.696

60.777

66.205

68.059

76.249

71.409

68.835

73.674

73.568

73.867

75.202

83.027

74.237

79.566

74.641

101.119

92.497

96.740

101.526

95.970

100.246

104.876

109.830

77.814

88.788

87.332

96.476 


\section{Sources:}

Farmer, David L., 'Crop Yields, Prices and Wages in Medieval England', Studies in Medieval and Renaissance History, 6 (1983), 117-55.

Farmer, David L., 'Prices and Wages', in H. E. Hallam, ed., The Agrarian History of England and Wales, Vol. II: 1042-1350 (Cambridge, 1988), pp. 760-78, 811-17.

Farmer, David L., 'Prices and Wages, 1350-1500', in Edward Miller, ed., The Agrarian History of England and Wales, Vol. III: 1348-1500 (Cambridge, 1991), pp. 467-90, 516-24

Note that Farmer's wage data do not go beyond 1500. 
Table 9. Nominal and Real Wages for Master Building Craftsmen in Small Towns of SE England:

in pence sterling and in index numbers

in quinquennial means: $1266-70$ to $1516-20$

Mean of $1451-75=100$

RWI $=$ NWI $/$ CPI

\begin{tabular}{|c|c|c|c|c|c|c|c|}
\hline $\begin{array}{l}5 \text { Year } \\
\text { Means }\end{array}$ & $\begin{array}{c}\text { Total } \\
\text { Value of } \\
\text { PBH } \\
\text { Basket } \\
\text { in d ster } \\
\text { Arithmetic } \\
\text { mean }\end{array}$ & $\begin{array}{l}\text { PBH Prices } \\
\text { Consumer } \\
\text { Price Index } \\
\text { Munro version } \\
\text { 1451-75=100 } \\
\text { Arithmetic } \\
\text { mean }\end{array}$ & $\begin{array}{l}\text { Master } \\
\text { Nominal } \\
\text { Day Wage } \\
\text { in d. for a } \\
\text { Arithmetic } \\
\text { mean }\end{array}$ & $\begin{array}{c}\text { Master Mason: } \\
\text { Nominal } \\
\text { Wage Index } \\
\text { 1451-75=100 } \\
\text { [= 6d. daily] } \\
\text { Arithmetic } \\
\text { mean }\end{array}$ & $\begin{array}{l}\text { Master Mason: } \\
\text { Real Wage } \\
\text { Index } \\
\text { (Munro) } \\
\text { 1451-75=100 } \\
\text { Harmonic } \\
\text { mean }\end{array}$ & $\begin{array}{l}\text { Index Numbers } \\
\text { Master RWI } \\
\text { No. of Baskets } \\
\text { Consumed in } \\
\text { one year } \\
1451-75=100 \\
\text { Harmonic } \\
\text { mean }\end{array}$ & $\begin{array}{l}\text { Master RWI } \\
\text { No. of Baskets } \\
\text { Consumed in } \\
\text { one year } \\
\text { (210 days) } \\
\text { Harmonic } \\
\text { mean }\end{array}$ \\
\hline $1266-70$ & 95.711 & 84.850 & 3.000 & 50.000 & 58.928 & 58.928 & 6.582 \\
\hline $1271-75$ & 119.267 & 105.733 & 3.000 & 50.000 & 47.289 & 47.289 & 5.282 \\
\hline $1275-80$ & 112.827 & 100.023 & 3.000 & 50.000 & 49.988 & 49.988 & 5.584 \\
\hline 1281-85 & 118.648 & 105.184 & 3.000 & 50.000 & 47.536 & 47.536 & 5.310 \\
\hline $1286-90$ & 92.444 & 81.953 & 3.000 & 50.000 & 61.010 & 61.010 & 6.815 \\
\hline 1291-95 & 118.863 & 105.375 & 3.000 & 50.000 & 47.450 & 47.450 & 5.300 \\
\hline $1296-1300$ & 113.122 & 100.285 & 3.000 & 50.000 & 49.858 & 49.858 & 5.569 \\
\hline 1301-05 & 103.414 & 91.679 & 3.300 & 55.000 & 59.714 & 59.714 & 6.670 \\
\hline $1306-10$ & 117.006 & 103.728 & 3.600 & 60.000 & 57.971 & 57.971 & 6.475 \\
\hline $1311-15$ & 124.580 & 110.443 & 4.000 & 66.667 & 60.363 & 60.363 & 6.743 \\
\hline $1316-20$ & 174.344 & 154.560 & 4.000 & 66.667 & 43.133 & 43.133 & 4.818 \\
\hline 1321-25 & 147.434 & 130.704 & 4.000 & 66.667 & 51.006 & 51.006 & 5.697 \\
\hline $1326-30$ & 118.116 & 104.712 & 4.000 & 66.667 & 63.666 & 63.666 & 7.112 \\
\hline 1331-35 & 123.074 & 109.108 & 4.000 & 66.667 & 61.102 & 61.102 & 6.825 \\
\hline $1336-40$ & 100.682 & 89.256 & 3.600 & 60.000 & 66.986 & 66.986 & 7.482 \\
\hline $1341-45$ & 96.482 & 85.533 & 3.000 & 50.000 & 58.457 & 58.457 & 6.530 \\
\hline $1346-50$ & 112.873 & 100.064 & 3.000 & 50.000 & 49.968 & 49.968 & 5.582 \\
\hline 1351-55 & 142.661 & 126.472 & 3.600 & 60.000 & 46.552 & 46.552 & 5.200 \\
\hline 1356-60 & 133.209 & 118.092 & 4.600 & 76.667 & 64.611 & 64.611 & 7.217 \\
\hline 1361-65 & 155.637 & 137.976 & 5.000 & 83.333 & 60.397 & 60.397 & 6.746 \\
\hline
\end{tabular}




\begin{tabular}{|c|c|}
\hline $\begin{array}{l}5 \text { Year } \\
\text { Means }\end{array}$ & $\begin{array}{c}\text { Total } \\
\text { Value of } \\
\text { PBH } \\
\text { Basket } \\
\text { in d ster } \\
\text { Arithmetic } \\
\text { mean }\end{array}$ \\
\hline $1366-70$ & 153.928 \\
\hline 1371-75 & 143.646 \\
\hline $1376-80$ & 123.958 \\
\hline 1381-85 & 127.679 \\
\hline $1386-90$ & 114.191 \\
\hline 1391-95 & 117.259 \\
\hline 1396-1400 & 124.812 \\
\hline 1401-05 & 127.073 \\
\hline $1406-10$ & 123.998 \\
\hline 1411-15 & 122.119 \\
\hline $1416-20$ & 128.139 \\
\hline 1421-25 & 117.020 \\
\hline $1426-30$ & 127.025 \\
\hline 1431-35 & 123.090 \\
\hline $1436-40$ & 140.118 \\
\hline 1441-45 & 104.424 \\
\hline $1446-50$ & 114.200 \\
\hline 1451-55 & 114.774 \\
\hline $1456-60$ & 110.500 \\
\hline 1451-65 & 114.489 \\
\hline $1466-70$ & 115.869 \\
\hline 1471-75 & 108.370 \\
\hline $1476-80$ & 104.529 \\
\hline 1481-85 & 136.921 \\
\hline $1486-90$ & 114.232 \\
\hline 1491-95 & 115.671 \\
\hline 1496-1500 & 111.152 \\
\hline 1501-05 & 120.005 \\
\hline 1506-10 & 118.499 \\
\hline 1511-15 & 119.584 \\
\hline $1516-20$ & 139.678 \\
\hline
\end{tabular}

PBH Prices

Consumer

Price Index

Munro version

1451-75=100

Arithmetic

mean

136.460
127.345
109.891
113.190
101.233
103.953
110.648
112.653
109.927
108.261
113.598
103.740
112.610
109.122
124.218
92.574
101.241
101.750
97.961
101.497
102.720
96.072
92.667
121.383
101.269
102.545
98.538
106.386
105.052
106.014
123.827

Master

Nominal

Day Wage

in d. for a

Arithmetic mean

$$
\begin{aligned}
& 5.000 \\
& 5.000 \\
& 5.000 \\
& 5.000 \\
& 5.000 \\
& 5.000 \\
& 5.000 \\
& 5.100 \\
& 5.800 \\
& 6.000 \\
& 6.000 \\
& 6.000 \\
& 6.000 \\
& 6.000 \\
& 6.000 \\
& 6.000 \\
& 6.000 \\
& 6.000 \\
& 6.000 \\
& 6.000 \\
& 6.000 \\
& 6.000 \\
& 6.000 \\
& 6.000 \\
& 6.000 \\
& 6.000 \\
& 6.000 \\
& 6.000 \\
& 6.000 \\
& 6.000 \\
& 6.000
\end{aligned}
$$

Index Numbers

Master RWI Master RWI

No. of Baskets No. of Baskets

Consumed in Consumed in

one year

one year

1451-75=100

Harmonic

(210 days)

Harmonic mean

6.821

7.310

8.471

8.224

9.195

8.955

8.413

8.395

9.843

10.318

9.833

10.767

9.919

10.236

8.992

12.066

11.033

10.978

11.403

11.005

10.874

11.627

12.054

9.202

11.030

10.893

11.336

10.500

10.633

10.537

9.021 


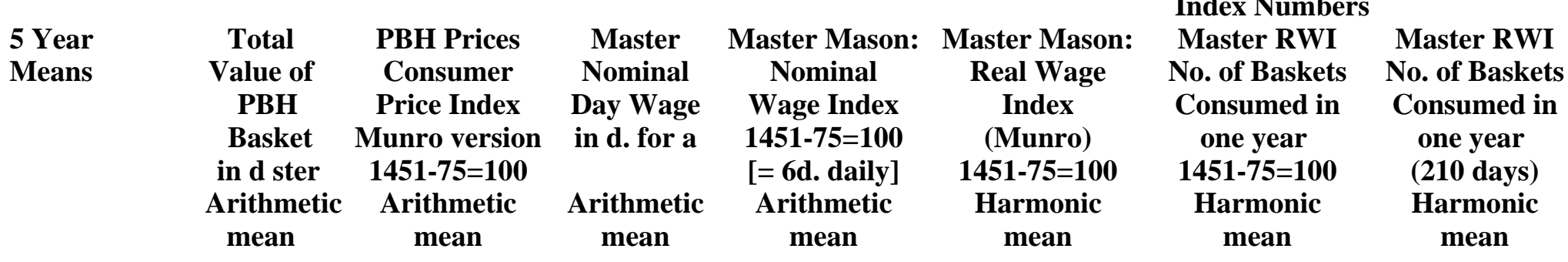

\section{Sources:}

(1) Prices:

Archives of the British Library of Economic and Political Science (LSE), The Phelps Brown Papers, BOX Ia: 324

(2) Wages:

Phelps Brown, E. Henry; and Sheila V. Hopkins, 'Seven Centuries of Building Wages’, Economica, 22:87 (August 1955), 195-206, reprinted in Henry Phelps Brown and Sheila Hopkins, A Perspective of Wages and Prices (London: Methuen, 1981), pp. 1- 12. 
Table 10.

Nominal and Real Wages of Building Labourers (Journeymen) in the Small Towns of SE England:

in pence and index numbers

in quinquennial means, $1266-70$ to 1516-20:

mean of 1451-75 $=100$

$\begin{array}{lc}\begin{array}{l}\text { Years } \\ \text { Five-Year } \\ \text { Means }\end{array} & \begin{array}{c}\text { Labourer } \\ \text { Nominal } \\ \text { Day Wage } \\ \text { in d. }\end{array} \\ & \text { Arithmetic } \\ \text { 1266-70 } & 1.500 \\ \mathbf{1 2 7 1 - 7 5} & 1.500 \\ \mathbf{1 2 7 6 - 8 0} & 1.500 \\ \mathbf{1 2 8 1 - 8 5} & 1.500 \\ \mathbf{1 2 8 6 - 9 0} & 1.500 \\ \mathbf{1 2 9 1 - 9 5} & 1.500 \\ \mathbf{1 2 9 6 - 1 3 0 0} & 1.500 \\ \mathbf{1 3 0 1 - 0 5} & 1.650 \\ \mathbf{1 3 0 6 - 1 0} & 1.800 \\ \mathbf{1 3 1 1 - 1 5} & 2.000 \\ \mathbf{1 3 1 6}-20 & 2.000 \\ \mathbf{1 3 2 1 - 2 5} & 2.000 \\ \mathbf{1 3 2 6}-30 & 2.000 \\ \mathbf{1 3 3 1}-35 & 2.000 \\ \mathbf{1 3 3 6 - 4 0} & 1.800 \\ \mathbf{1 3 4 1 - 4 5} & 1.500 \\ \mathbf{1 3 4 6 - 5 0} & 1.500 \\ \mathbf{1 3 5 1 - 5 5} & 1.800 \\ \mathbf{1 3 5 6 - 6 0} & 2.600 \\ \mathbf{1 3 6 1 - 6 5} & 3.000 \\ \mathbf{1 3 6 6 - 7 0} & 3.000 \\ \mathbf{1 3 7 1 - 7 5} & 3.000 \\ & \end{array}$

$\begin{array}{ccc}\begin{array}{c}\text { Labourer's } \\ \text { Wage as }\end{array} & \begin{array}{c}\text { Mason Labourer } \\ \text { Nominal }\end{array} & \begin{array}{c}\text { Mason Labourer } \\ \text { Real Wage }\end{array} \\ \text { Percent } & \text { Wage Index } & \text { Index } \\ \text { of Master } & 1451-75=100 & \text { (Munro) } \\ & {[=4 d \text {. daily] }} & 1451-75=100 \\ \text { Arithmetic } & \text { Arithmetic } & \text { Harmonic }\end{array}$

Master RWI
No. of Baskets
Consumed in
one year
(210 days)
Harmonic

44.196

$50.00 \%$

$50.00 \%$

$50.00 \%$

$50.00 \%$

$50.00 \%$

$50.00 \%$

$50.00 \%$

$50.00 \%$

$50.00 \%$

$50.00 \%$

$50.00 \%$

$50.00 \%$

$50.00 \%$

$50.00 \%$

$50.00 \%$

$50.00 \%$

$50.00 \%$

$50.00 \%$

$56.22 \%$

$60.00 \%$

$60.00 \%$

0.600
37.500

37.500

37.500

37.500

37.500

37.500

37.500

41.250

45.000

50.000

50.000

50.000

50.000

50.000

45.000

37.500

37.500

45.000

65.000

75.000

75.000

75.000
35.467

37.491

35.652

45.758

35.587

37.393

44.786

43.478

45.272

32.350

38.254

47.750

45.826

51.019

43.843

37.476

34.914

54.039

54.357

54.961

58.895
Labourer RWI

No. of Baskets

Consumed in

one year

(210 days)

Harmonic

$\begin{array}{ll}6.582 & 3.291 \\ 5.282 & 2.641 \\ 5.584 & 2.792 \\ 5.310 & 2.655 \\ 6.815 & 3.407 \\ 5.300 & 2.650 \\ 5.569 & 2.785 \\ 6.670 & 3.335 \\ 6.475 & 3.238 \\ 6.743 & 3.371 \\ 4.818 & 2.409 \\ 5.697 & 2.849 \\ 7.112 & 3.556 \\ 6.825 & 3.413 \\ 7.482 & 3.741 \\ 6.530 & 3.265 \\ 5.582 & 2.791 \\ 5.200 & 2.600 \\ 7.217 & 4.024 \\ 6.746 & 4.048 \\ 6.821 & 4.093 \\ 7.310 & 4.386\end{array}$




\begin{tabular}{|c|c|c|c|c|c|c|}
\hline $\begin{array}{l}\text { Years } \\
\text { Five-Year } \\
\text { Means }\end{array}$ & $\begin{array}{c}\text { Labourer } \\
\text { Nominal } \\
\text { Day Wage } \\
\text { in d. } \\
\text { Arithmetic }\end{array}$ & $\begin{array}{c}\text { Labourer's } \\
\text { Wage as } \\
\text { Percent } \\
\text { of Master } \\
\text { Arithmetic }\end{array}$ & $\begin{array}{c}\text { Mason Labourer } \\
\text { Nominal } \\
\text { Wage Index } \\
\text { 1451-75 = 100 } \\
\text { [= 4d. daily] } \\
\text { Arithmetic }\end{array}$ & $\begin{array}{c}\text { Mason Labourer } \\
\text { Real Wage } \\
\text { Index } \\
\text { (Munro) } \\
\text { 1451-75 = 100 } \\
\text { Harmonic }\end{array}$ & $\begin{array}{l}\text { Master RWI } \\
\text { No. of Baskets } \\
\text { Consumed in } \\
\text { one year } \\
\text { (210 days) } \\
\text { Harmonic }\end{array}$ & $\begin{array}{l}\text { Labourer RWI } \\
\text { No. of Baskets } \\
\text { Consumed in } \\
\text { one year } \\
\text { (210 days) } \\
\text { Harmonic }\end{array}$ \\
\hline 1376-80 & 3.000 & 0.600 & 75.000 & 68.249 & 8.471 & 5.082 \\
\hline 1381-85 & 3.000 & 0.600 & 75.000 & 66.260 & 8.224 & 4.934 \\
\hline 1386-90 & 3.000 & 0.600 & 75.000 & 74.087 & 9.195 & 5.517 \\
\hline 1391-95 & 3.000 & 0.600 & 75.000 & 72.148 & 8.955 & 5.373 \\
\hline 1396-1400 & 3.000 & 0.600 & 75.000 & 67.782 & 8.413 & 5.048 \\
\hline 1401-05 & 3.200 & 0.627 & 80.000 & 70.065 & 8.395 & 5.218 \\
\hline $1406-10$ & 3.800 & 0.655 & 95.000 & 86.562 & 9.843 & 6.446 \\
\hline 1411-15 & 4.000 & 0.667 & 100.000 & 92.369 & 10.318 & 6.879 \\
\hline $1416-20$ & 4.000 & 0.667 & 100.000 & 88.030 & 9.833 & 6.555 \\
\hline $1421-25$ & 4.000 & 0.667 & 100.000 & 96.395 & 10.767 & 7.178 \\
\hline $1426-30$ & 4.000 & 0.667 & 100.000 & 88.802 & 9.919 & 6.613 \\
\hline 1431-35 & 4.000 & 0.667 & 100.000 & 91.801 & 10.236 & 6.824 \\
\hline $1436-40$ & 4.000 & 0.667 & 100.000 & 80.504 & 8.992 & 5.995 \\
\hline 1441-45 & 4.000 & 0.667 & 100.000 & 108.022 & 12.066 & 8.044 \\
\hline $1446-50$ & 4.000 & 0.667 & 100.000 & 98.774 & 11.033 & 7.356 \\
\hline 1451-55 & 4.000 & 0.667 & 100.000 & 98.280 & 10.978 & 7.319 \\
\hline $1456-60$ & 4.000 & 0.667 & 100.000 & 102.082 & 11.403 & 7.602 \\
\hline 1461-65 & 4.000 & 0.667 & 100.000 & 98.525 & 11.005 & 7.337 \\
\hline $1466-70$ & 4.000 & 0.667 & 100.000 & 97.352 & 10.874 & 7.250 \\
\hline $1471-75$ & 4.000 & 0.667 & 100.000 & 104.088 & 11.627 & 7.751 \\
\hline $1476-80$ & 4.000 & 0.667 & 100.000 & 107.913 & 12.054 & 8.036 \\
\hline 1481-85 & 4.000 & 0.667 & 100.000 & 82.384 & 9.202 & 6.135 \\
\hline $1486-90$ & 4.000 & 0.667 & 100.000 & 98.747 & 11.030 & 7.353 \\
\hline 1491-95 & 4.000 & 0.667 & 100.000 & 97.518 & 10.893 & 7.262 \\
\hline 1496-1500 & 4.000 & 0.667 & 100.000 & 101.483 & 11.336 & 7.557 \\
\hline 1501-05 & 4.000 & 0.667 & 100.000 & 93.997 & 10.500 & 7.000 \\
\hline $1506-10$ & 4.000 & 0.667 & 100.000 & 95.191 & 10.633 & 7.089 \\
\hline 1511-15 & 4.000 & 0.667 & 100.000 & 94.327 & 10.537 & 7.024 \\
\hline $1516-20$ & 4.000 & 0.667 & 100.000 & 80.758 & 9.021 & 6.014 \\
\hline
\end{tabular}

\section{Sources:}

(1) Prices: Archives of the British Library of Economic and Political Science (LSE), The Phelps Brown Papers, BOX Ia: 324 
(2) Wages: Phelps Brown, E. Henry; and Sheila V. Hopkins, 'Seven Centuries of Building Wages', Economica, 22:87 (August 1955), 195-206, reprinted in Henry Phelps Brown and Sheila Hopkins, A Perspective of Wages and Prices (London: Methuen, 1981), pp. 1- 12. 
Table 11. Wages of Master Building Craftsmen in Bruges

In quinquennial means: 1351-55 to 1496-1500

in pence (d) groot Flemish and in Flemish commodity baskets

with Consumer Price, Nominal Wage, and Real Wage Indexes (1451-75=100)

Year

1351-55

1356-60

1361-65

1366-70

1371-75

1376-80

1381-85

1386-90

1391-95

1396-1400

1401-05

1406-10

1411-15

1416-20

1421-25

1426-30

1431-35

1436-40

1441-45

1446-50

1451-55

1456-60

1461-65

1466-70

1471-75

\section{Basket of \\ Consumables \\ Total Value \\ in $\mathbf{d}$ \\ groot}

Commodity
Basket

Price Index
1451-75=100
126.295d
groot
Flemish

76.593

110.558

119.255

135.641

145.519

141.024

150.534

157.514

111.784

113.407

111.810

132.939

120.370

135.616

141.680

148.741

155.989

177.022

143.350

138.904

127.434

148.845

112.030

121.900

121.264

\section{Wages of Master Building Craftsmen \\ in Bruges in $\mathrm{d}$ gr. Best estimate of median wage}

60.646
87.540
94.425
107.401
115.222
111.662
119.193
124.719
88.510
89.796
88.531
105.261
95.309
107.381
112.182
117.773
123.512
140.166
113.504
109.984
100.902
117.855
88.705
96.520
96.017

60.646

94.425

107.401

111.662

88.510

105.261

12.182

117.773

140.166

100.902

88.705

96.017

\section{Bruges \\ Nominal Wage Index \\ Mean Mode 1451-75=100 [11d groot Flem]}

5.200

6.000

6.850

8.000

8.000

8.800

8.800

10.867

9.000
9.850

10.000

10.000

10.000

10.000

10.000

10.000

10.800

11.000

11.000

11.000

11.000

11.000

11.000

11.000

11.000
Bruges

Real Wage Index

$1451-75=100$

harmonic

mean

47.273

54.545

62.273

72.727

72.727

80.000

80.000

98.788

81.818

89.545

90.909

90.909

90.909

90.909

90.909

90.909

98.182

100.000

100.000

100.000

100.000

100.000

100.000

100.000

100.000
Real Wage

in Commodity

Baskets

Annual: 210 days

harmonic

mean

14.188

77.572

62.309

65.366

67.716

63.120

70.520

65.898

77.375

92.439

99.731

102.687

86.366

95.384

84.660

81.037

77.190

79.378

71.344

88.102

90.922

99.106

84.850

112.733

103.605

104.148
11.397

11.956

12.386

11.545

12.898

12.053

14.152

16.908

18.241

18.782

15.797

17.446

15.485

14.822

14.118

14.519

13.049

16.114

16.630

18.127

15.519

20.619

18.950

19.049 


\begin{tabular}{|c|c|c|c|c|c|c|}
\hline \multirow[t]{2}{*}{ Year } & $\begin{array}{c}\text { Basket of } \\
\text { Consumables }\end{array}$ & $\begin{array}{l}\text { Commodity } \\
\text { Basket }\end{array}$ & $\begin{array}{c}\text { Wages of Master } \\
\text { Building } \\
\text { Craftsmen }\end{array}$ & $\begin{array}{c}\text { Bruges } \\
\text { Nominal Wage } \\
\text { Index }\end{array}$ & $\begin{array}{c}\text { Bruges } \\
\text { Real Wage Index }\end{array}$ & $\begin{array}{c}\text { Real Wage } \\
\text { in Commodity } \\
\text { Baskets }\end{array}$ \\
\hline & $\begin{array}{l}\text { Total Value } \\
\text { in d } \\
\text { groot }\end{array}$ & $\begin{array}{c}\text { Price Index } \\
\text { 1451-75=100 } \\
\text { 126.295d } \\
\text { groot } \\
\text { Flemish }\end{array}$ & $\begin{array}{l}\text { in Bruges in d gr. } \\
\text { Best estimate of } \\
\text { median wage }\end{array}$ & $\begin{array}{c}\text { Mean Mode } \\
\text { 1451-75=100 } \\
\text { [11d groot Flem] }\end{array}$ & $\begin{array}{c}\text { 1451-75=100 } \\
\text { harmonic } \\
\text { mean }\end{array}$ & $\begin{array}{c}\text { Annual: } 210 \text { days } \\
\text { harmonic } \\
\text { mean }\end{array}$ \\
\hline 1476-80 & 148.034 & 117.213 & 11.000 & 100.000 & 85.315 & 15.605 \\
\hline 1481-85 & 198.097 & 156.853 & 11.000 & 100.000 & 63.754 & 11.661 \\
\hline 1486-90 & 233.028 & 184.511 & & & & \\
\hline 1491-95 & 183.104 & 144.981 & & & & \\
\hline 1496-1500 & 126.617 & 100.255 & & & & \\
\hline
\end{tabular}

\section{Sources:}

See sources for Table 10, and also:

Stadsarchief Brugge, Stadsrekeningen, 1350/51 to 1475/76.

Jean-Pierre Sosson, Les travaux de la ville de Bruges, XIVe - XVe siècles: les matériaux, les hommes, Collection Histoire Pro Civitate no. 48 (Brussels: Credit Communal de Belgique, 1977), pp. 225-32; Tables 13-15, pp. 301-03.

Note that these sources do not provide price data for this commodity basket either before 1350 or after 1500; and the archival expenditure accounts for Bruges cease providing individual wage data in the late 1480s. 
Table 12. Wages of Journeymen Building Labourers in Bruges

In quinquennial means: 1351-55 to 1496-1500

in pence (d) groot Flemish and in Flemish commodity baskets with Consumer Price, Nominal Wage, and Real Wage Indexes (1451-75=100)

in quinquennial means, $1351-55$ to $1496-1500$

$\begin{array}{cc}\text { Year } & \text { Basket } \\ & \text { Consumables } \\ \text { Total Value } \\ \text { in d } \\ \text { groot Flemish }\end{array}$

1351-55

1356-60

1361-65

1366-70

1371-75

1376-80

1381-85

1386-90

1391-95

1396-1400

1401-05

1406-10

1411-15

1416-20

1421-25

1426-30

1431-35

1436-40

1441-45

1446-50

1451-55

$\begin{array}{cc}\begin{array}{c}\text { Commodity } \\ \text { Basket }\end{array} & \begin{array}{c}\text { Wages of } \\ \text { Journeymen }\end{array} \\ \text { Price Index } & \text { Building } \\ \text { 1451-75=100 } & \text { Craftsmen } \\ 126.295 & \text { in d groot }\end{array}$

d groot

Flemish

\section{Nominal \\ Wage \\ Index \\ 1451-75= \\ 100 \\ (5.5 d)}

76.593

110.558

119.255

135.641

145.519

141.024

150.534

157.514

111.784

113.407

111.810

132.939

120.370

135.616

141.680

148.741

155.989

177.022

143.350

138.904

127.434

$$
\begin{array}{r}
60.646 \\
87.540 \\
94.425 \\
107.401 \\
115.222 \\
111.662 \\
119.193 \\
124.719 \\
88.510 \\
89.796 \\
88.531 \\
105.261 \\
95.309 \\
107.381 \\
112.182 \\
117.773 \\
123.512 \\
140.166 \\
113.504 \\
109.984 \\
100.902
\end{array}
$$

Real

Wage Index

$1451-75=$

100

harmonic

mean

\section{Commodity \\ Baskets \\ for annual \\ money wage \\ of journeymen}

builder

harmonic mean

$\begin{array}{rr}77.572 & 7.094 \\ 62.309 & 5.698 \\ 65.366 & 5.978 \\ 67.716 & 6.193 \\ 63.120 & 5.772 \\ 70.520 & 6.449 \\ 65.898 & 6.027 \\ 77.375 & 7.076 \\ 92.439 & 8.454 \\ 99.731 & 9.121 \\ 102.687 & 9.391 \\ 86.366 & 7.898 \\ 95.384 & 8.723 \\ 84.660 & 7.742 \\ 81.037 & 7.411 \\ 77.190 & 7.059 \\ 79.378 & 7.259 \\ 71.344 & 6.525 \\ 88.102 & 8.057 \\ 90.922 & 8.315 \\ 99.106 & 9.063\end{array}$

7.094

54.545

62.273

72.727

72.727

80.000

80.000

98.788

81.818

89.545

90.909

90.909

90.909

90.909

90.909

90.909

98.182

100.000

100.000

100.000

100.000
5.698

6.193

6.027

7.076

391

7.898

8.723

7.059

8.057

9.063 


\begin{tabular}{|c|c|c|c|c|c|c|}
\hline Year & $\begin{array}{c}\text { Basket } \\
\text { Consumables } \\
\text { Total Value } \\
\text { in d } \\
\text { groot Flemish }\end{array}$ & $\begin{array}{c}\text { Commodity } \\
\text { Basket } \\
\text { Price Index } \\
\text { 1451-75=100 } \\
126.295 \\
\\
\text { d groot } \\
\text { Flemish }\end{array}$ & $\begin{array}{c}\text { Wages of } \\
\text { Journeymen } \\
\text { Building } \\
\text { Craftsmen } \\
\text { in d groot } \\
\text { Flemish }\end{array}$ & $\begin{array}{c}\text { Nominal } \\
\text { Wage } \\
\text { Index } \\
\text { 1451-75= } \\
100 \\
(5.5 \mathrm{~d})\end{array}$ & 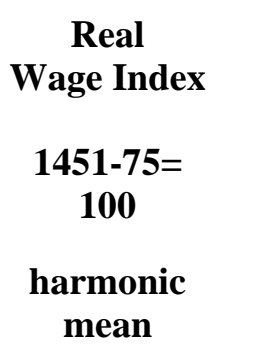 & $\begin{array}{c}\text { Commodity } \\
\text { Baskets } \\
\text { for annual } \\
\text { money wage } \\
\text { of journeymen } \\
\text { builder } \\
\text { harmonic mean }\end{array}$ \\
\hline $1456-60$ & 148.845 & 117.855 & 5.500 & 100.000 & 84.850 & 7.760 \\
\hline 1461-65 & 112.030 & 88.705 & 5.500 & 100.000 & 112.733 & 10.310 \\
\hline $1466-70$ & 121.900 & 96.520 & 5.500 & 100.000 & 103.605 & 9.475 \\
\hline 1471-75 & 121.264 & 96.017 & 5.500 & 100.000 & 104.148 & 9.525 \\
\hline $1476-80$ & 148.034 & 117.213 & 5.500 & 100.000 & 85.315 & 7.802 \\
\hline 1481-85 & 198.097 & 156.853 & 5.500 & 100.000 & 63.754 & 5.830 \\
\hline 1486-90 & 233.028 & 184.511 & & & & \\
\hline 1491-95 & 183.104 & 144.981 & & & & \\
\hline 1496-1500 & 126.617 & 100.255 & & & & \\
\hline
\end{tabular}

\section{Sources:}

See sources for Table 11, and also:

Stadsarchief Brugge, Stadsrekeningen, 1350/51 to 1475/76.

Jean-Pierre Sosson, Les travaux de la ville de Bruges, XIVe - XVe siècles: les matériaux, les hommes, Collection Histoire Pro Civitate no. 48 (Brussels: Credit Communal de Belgique, 1977), pp. 225-32; Tables 13-15, pp. 301-03.

Note that these sources do not provide price data for this commodity basket either before 1350 or after 1500; and the archival expenditure accounts for Bruges cease providing individual wage data in the late 1480s. 
Table 13.

Years

5 Year Means

Silver Outputs in

kg fine metal
$8,550.489$

$3,559.688$

22,194.388

21,913.309

$17,280.596$

$1,552.352$

$12,071.417$

$16,017.465$

40,226.553

$10,706.712$

$7,275.676$

$1,780.107$

121.857

209.056

429.488
$5,077.456$

$1,991.051$

$17,442.905$

4,423.016

$1,630.811$

293.822

316.966

356.898

317.412

247.514

193.489

175.596

66.344

10.592

$3,186.020$
English Mint Outputs of Silver and Gold Coinage,

in kilograms of pure silver and gold

and in current pounds sterling values

in quinquennial means, $1266-70$ to $1516-20$ Value of Silver in Gold Outputs in

E sterling

kg fine metal

Value of Gold in
$£$ sterling

$$
\begin{array}{r}
26,637.383 \\
11,089.515 \\
69,353.587 \\
68,548.734 \\
54,056.784 \\
4,856.034 \\
37,761.545 \\
50,105.484 \\
125,835.827 \\
33,492.502 \\
22,759.610 \\
5,568.492 \\
381.190 \\
665.131 \\
1,551.599 \\
17,710.473 \\
7,090.874 \\
67,245.275 \\
17,081.461 \\
6,298.107 \\
1,134.727 \\
1,224.108 \\
1,378.322 \\
1,225.829 \\
955.887 \\
747.245 \\
678.143 \\
256.216 \\
40.907 \\
4,483.340 \\
3,882.476 \\
14,765.093 \\
\end{array}
$$

Total

Value in

E sterling

$$
\begin{array}{r}
26,637.383 \\
11,089.515 \\
69,353.587 \\
68,548.734 \\
54,056.784 \\
4,856.034 \\
37,761.545 \\
50,105.484 \\
125,835.827 \\
33,492.502 \\
22,759.610 \\
5,568.492 \\
381.190 \\
665.131 \\
1,551.599 \\
27,569.958 \\
34,214.171 \\
150,813.007 \\
91,488.305 \\
110,375.864 \\
75,642.079 \\
35,810.127 \\
11,519.169 \\
8,199.633 \\
22,709.218 \\
27,746.397 \\
17,533.285 \\
7,524.606 \\
3,014.475 \\
94,003.236 \\
53,445.552 \\
137,209.462 \\
\end{array}
$$


Years

5 Year Means
Silver Outputs in

kg fine metal
Value of Silver in

E sterling
Gold Outputs in

kg fine metal

\section{Value of Gold in \\ E sterling}

Total

Value in

E sterling

\begin{tabular}{|c|c|c|c|c|c|}
\hline $1426-30$ & $6,858.608$ & $31,785.107$ & 599.478 & 28,703.069 & $60,488.176$ \\
\hline 1431-35 & $8,059.545$ & $37,350.656$ & 220.785 & $10,571.183$ & $47,921.839$ \\
\hline $1436-40$ & 977.025 & $4,527.863$ & 132.274 & 6,333.298 & $10,861.161$ \\
\hline 1441-45 & 130.700 & 605.707 & 90.778 & $4,346.467$ & $4,952.174$ \\
\hline $1446-50$ & 517.373 & $2,397.681$ & 64.336 & $3,080.422$ & $5,478.103$ \\
\hline 1451-55 & $1,460.637$ & $6,769.085$ & 63.526 & $3,041.629$ & $9,810.714$ \\
\hline $1456-60$ & $1,415.094$ & $6,558.024$ & 26.719 & $1,279.288$ & $7,837.312$ \\
\hline 1461-65 & $3,432.915$ & $18,067.349$ & 488.118 & 29,731.331 & $47,798.679$ \\
\hline $1466-70$ & $5,168.090$ & $29,938.348$ & $1,288.157$ & $83,263.992$ & $113,202.339$ \\
\hline 1471-75 & $2,422.654$ & $14,034.247$ & 538.669 & $34,818.552$ & $48,852.799$ \\
\hline $1476-80$ & 834.683 & $4,835.252$ & 404.477 & $26,144.624$ & $30,979.875$ \\
\hline 1481-85 & 995.231 & $5,765.296$ & 219.449 & $14,184.753$ & $19,950.049$ \\
\hline $1486-90$ & 926.785 & $5,368.794$ & 129.749 & $8,386.730$ & $13,755.524$ \\
\hline 1491-95 & $1,270.840$ & $7,361.876$ & 268.983 & $17,386.525$ & $24,748.402$ \\
\hline $1496-1500$ & $2,490.940$ & $14,429.823$ & 278.926 & $18,029.238$ & $32,459.060$ \\
\hline 1501-05 & $4,313.544$ & $24,988.026$ & 516.604 & $33,392.271$ & $58,380.297$ \\
\hline 1506-10 & $3,633.212$ & $21,046.916$ & $1,523.115$ & $98,451.267$ & $119,498.183$ \\
\hline 1511-15 & $1,089.012$ & $6,308.562$ & 694.599 & $44,897.564$ & $51,206.126$ \\
\hline $1516-20$ & 79.145 & 458.481 & 743.656 & $48,068.530$ & $48,527.011$ \\
\hline
\end{tabular}

\section{Sources:}

Christopher Challis, ‘Appendix 1: Mint Output, 1220-1985,' in Christopher Challis, ed., A New History of the Royal Mint, (Cambridge, 1992), pp. 673698; John Munro, Wool, Cloth, and Gold: The Struggle for Bullion in Anglo-Burgundian Trade, ca. 1340-1478 (Brussels, 1973); John Munro, 'Mint Policies, Ratios, and Outputs in England and the Low Countries, 1335-1420: Some Reflections on New Data,' The Numismatic Chronicle, 141 (1981), 71-116; John Munro, 'Bullion Flows and Monetary Contraction in Late-Medieval England and the Low Countries,' in John F. Richards, ed., Precious Metals in the Later Medieval and Early Modern Worlds (Durham, 1983), pp. 97-158; John Munro, 'Wage-Stickiness, Monetary Changes, and Real Incomes in Late-Medieval England and the Low Countries, 1300 - 1500: Did Money Matter?’ Research in Economic History, 21 (2003), 185 - 297. 
in Quinquennial Means: 1336-40 to 1516-20

\begin{tabular}{l} 
Year \\
5 yr means \\
\\
$1336-40$ \\
$1341-45$ \\
$1346-50$ \\
$1351-55$ \\
$1356-60$ \\
$1361-65$ \\
$1366-70$ \\
$1371-75$ \\
$1376-80$ \\
$1381-85$ \\
$1386-90$ \\
$1391-95$ \\
$1396-1400$ \\
$1401-05$ \\
$1406-10$ \\
$1411-15$ \\
$1416-20$ \\
$1421-25$ \\
$1426-30$ \\
$1431-35$ \\
$1436-40$ \\
$1441-45$ \\
$1446-50$ \\
$1451-55$ \\
$1456-60$ \\
$1461-65$ \\
$1466-70$ \\
$1471-75$ \\
$1476-80$ \\
$1481-85$ \\
\hline
\end{tabular}

$\begin{array}{rr}\begin{array}{r}\text { Silver Outputs } \\ \text { in kg. }\end{array} & \begin{array}{r}\text { Silver Outputs } \\ \text { in } £ \text { groot }\end{array} \\ & \\ 3,566.806 & 4,773.974 \\ 294.601 & 518.100 \\ 5,915.310 & 11,864.293 \\ 5,178.951 & 11,397.252 \\ 8,820.730 & 21,251.516 \\ 3,992.165 & 11,141.966 \\ 10,347.518 & 33,290.674 \\ 4,852.022 & 18,208.349 \\ 1,898.960 & 7,567.387 \\ 2,816.883 & 11,467.496 \\ 2,013.492 & 8,723.712 \\ 3,676.062 & 14,958.400 \\ 5,791.306 & 23,507.520 \\ 691.661 & 2,826.540 \\ 1,113.700 & 3,887.994 \\ 2,484.269 & 8,665.846 \\ 3,124.468 & 15,052.698 \\ 12,143.547 & 57,614.792 \\ 7,999.913 & 43,326.036 \\ 6,609.816 & 34,252.100 \\ 5,015.219 & 25,788.306 \\ 102.683 & 527.552 \\ 5.911 & 40.786 \\ 164.611 & 880.316 \\ 64.066 & 408.310 \\ 0.000 & 0.000 \\ 4,628.964 & 27,867.694 \\ 7,313.984 & 45,191.724 \\ 9,341.495 & 67,636.248 \\ 6,534.304 & 56,337.178\end{array}$

Gold Outputs
in kg.

261.325
2.203
336.550
$1,096.661$
$3,191.827$
$2,629.891$
$1,636.694$
$1,807.028$
541.721
529.809
465.426
368.614
324.589
31.535
19.025
5.884
4.308
41.056
$1,105.072$
$1,774.868$
511.935
111.931
2.550
827.293
253.139
6.596
253.594
261.202
380.051
58.536

$\begin{array}{rr}\begin{array}{r}\text { Gold Outputs } \\ \text { in } £ \text { groot }\end{array} & \begin{array}{r}\text { Total Value } \\ \text { in } £ \text { groot }\end{array} \\ & \\ 3,894.553 & 8,668.528 \\ 44.333 & 562.433 \\ 7,026.127 & 18,890.420 \\ 24,811.554 & 36,208.806 \\ 80,870.028 & 102,121.544 \\ 77,350.494 & 88,492.460 \\ 51,788.717 & 85,079.391 \\ 72,090.390 & 90,298.739 \\ 21,890.920 & 29,458.308 \\ 22,941.630 & 34,409.126 \\ 22,891.085 & 31,614.797 \\ 14,458.242 & 29,416.642 \\ 12,731.424 & 36,238.944 \\ 1,236.902 & 4,063.442 \\ 636.250 & 4,524.244 \\ 196.762 & 8,862.608 \\ 181.634 & 15,234.332 \\ 2,195.696 & 59,810.488 \\ 69,470.308 & 112,796.344 \\ 115,363.244 & 149,615.344 \\ 28,534.390 & 54,322.696 \\ 6,466.290 & 6,993.842 \\ 148.084 & 188.870 \\ 50,701.692 & 51,582.008 \\ 15,513.918 & 15,922.228 \\ 404.224 & 404.224 \\ 16,400.726 & 44,268.420 \\ 18,927.514 & 64,119.238 \\ 29,208.498 & 96,844.746 \\ 5,216.392 & 61,553.570\end{array}$


Year

5 yr means

1486-90

1491-95

1496-1500

1501-05

1510-15

1516-20
Silver Outputs

in $\mathrm{kg}$.

6,803.602

2,780.071

$5,345.911$

3,157.836

$1,640.383$

705.122
Silver Outputs

in $£$ groot

78,323.898

$19,521.098$

44,764.905

26,902.913

$14,074.127$

$6,152.620$
Gold Outputs

in kg.

144.641

20.320

474.633

538.871

257.699

145.094
Gold Outputs

in $£$ groot

24,136.964

$1,336.340$

$44,464.280$

$51,112.530$

$24,459.800$

$13,779.872$
Total Value in $£$ groot

$102,460.862$

$20,857.438$

$89,229.185$

$78,015.442$

$38,533.927$

$19,932.492$

\section{Sources:}

Archival sources listed in John Munro, Wool, Cloth, and Gold: The Struggle for Bullion in Anglo-Burgundian Trade, 1340 - 1478 (Brussels and Toronto, 1973), Appendix I, pp. 193-197; and Tables C - K, pp. 198-211.

See also John Munro, 'The Monetary Origins of the "Price Revolution:” South German Silver Mining, Merchant-Banking, and Venetian Commerce, 1470-1540', in Dennis Flynn, Arturo Giráldez, and Richard von Glahn, eds., Global Connections and Monetary History, 1470 - 1800 (Aldershot and Brookfield, Vt: Ashgate Publishing, 2003), pp. 1-34; and the sources cited for Table 1 above. 


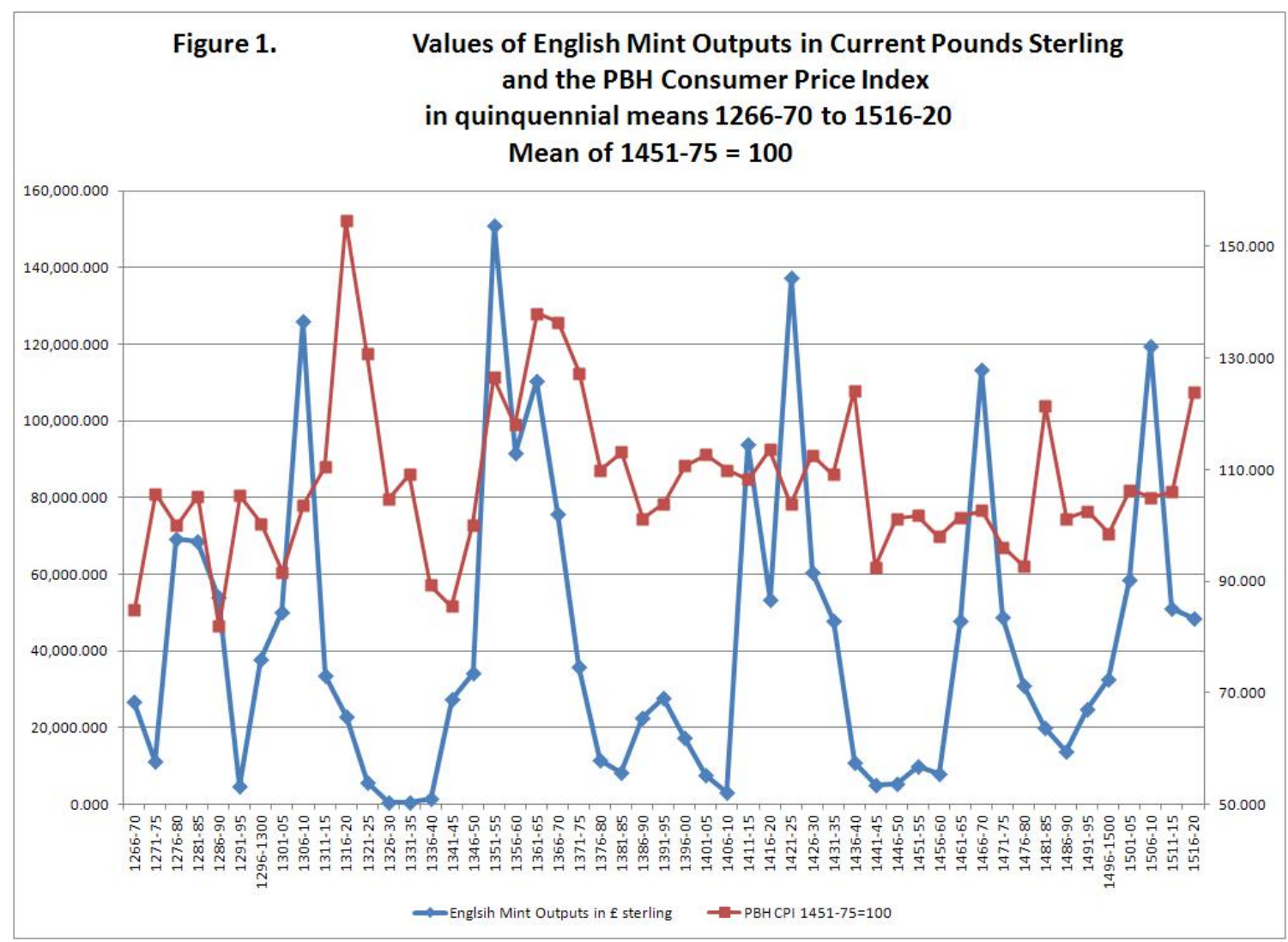

\section{Sources:}

(1) Mint Outputs:

Christopher Challis, 'Appendix 1: Mint Output, 1220-1985,' in Christopher Challis, ed., A New History of the Royal Mint, (Cambridge, 1992), pp. 673-698; John Munro, Wool, Cloth, and Gold: The Struggle for Bullion in Anglo-Burgundian Trade, ca. 1340-1478 (Brussels, 1973); John Munro, 'Mint Policies, Ratios, and Outputs in England and the Low Countries, 1335-1420: Some Reflections on New Data,' The Numismatic Chronicle, 141 (1981), 71-116; John Munro, 'Bullion Flows and Monetary Contraction in Late-Medieval England and the Low Countries,' in John F. Richards, ed., Precious Metals in the Later Medieval and Early Modern Worlds (Durham, 1983), pp. 97-158; John Munro, 'Wage-Stickiness, Monetary Changes, and Real Incomes in Late-Medieval England and the Low Countries, 1300 - 1500: Did Money Matter?' Research in Economic History, 21 (2003), 185 - 297.

(2) Prices:

Archives of the British Library of Economic and Political Science (London School of Economics), The Phelps Brown Papers, BOX Ia: 324. This significantly revised version should be compared with the the price indexes in the original version presented in E. Henry Phelps Brown and Sheila Hopkins, 'Seven Centuries of the Prices of Consumables, Compared with Builders' Wage Rates', Economica, 23:92 (November 1956), 296-314; reprinted in E.H. Phelps Brown and Sheila V. Hopkins, A Perspective of Wages and Prices (London, 1981), pp. 13-39 (with price indexes not in the original). 


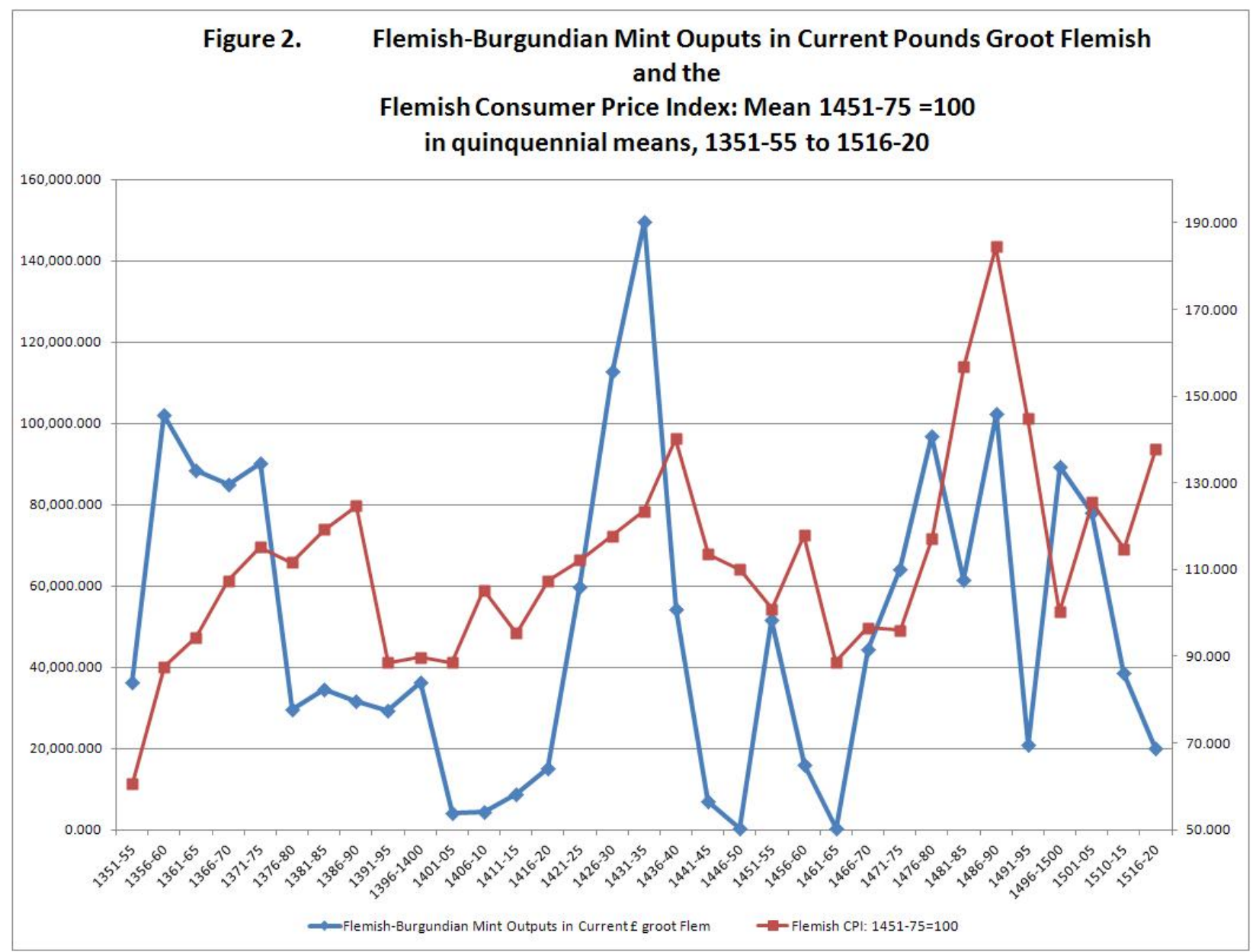

\section{Sources:}

(1) Mint Outputs:

Archival sources listed in John Munro, Wool, Cloth, and Gold: The Struggle for Bullion in AngloBurgundian Trade, 1340 - 1478 (Brussels and Toronto, 1973), Appendix I, pp. 193-197; and Tables C - K, pp. 198-211; John Munro, 'The Monetary Origins of the "Price Revolution:" South German Silver Mining, Merchant-Banking, and Venetian Commerce, 1470-1540', in Global Connections and Monetary History, 1470 - 1800, ed. Dennis Flynn, Arturo Giráldez, and Richard von Glahn (Aldershot: Ashgate Publishing, 2003), pp. 1-34.

(2) Prices:

Charles Verlinden, E. Scholliers, and J. Craeybeckx, eds., Documents pour l'histoire des prix et des salaires en Flandre et en Brabant/Dokumenten voor de geschiedenis van prijzen en lonen in Vlaanderen en Brabant, 2 vols., Rijksuniveristeit te Gent: Werken Uitgegeven door de Faculteit van de Letteren en Wijsbegeerte nos. 125, 136, 137 (Bruges, 1959-65), Vols. I, IIi., and II.ii. John Munro, 'Wage-Stickiness, Monetary Changes, and Real Incomes in Late-Medieval England and the Low Countries, 1300 - 1500: Did Money Matter?' Research in Economic History, 21 (2003), 185 - 297; Stadsarchief Gent, Stadsrekeningen, Reeks 400:7 - 35 (for cloth prices) 
